\title{
Pteridófitas do Parque Estadual de Vila Velha, Ponta Grossa, Paraná, Brasil
}

\author{
Pedro Bond Schwartsburd ${ }^{1,2}$ e Paulo Henrique Labiak ${ }^{1}$
}

Recebido: 09.11.2006; aceito: 10.05.2007

\begin{abstract}
Pteridophytes from Vila Velha State Park, Ponta Grossa, Paraná, Brazil). In this work we present a floristic survey of the pteridophytes from the Vila Velha State Park, Ponta Grossa, Paraná. Vila Velha presents an area of 3,803.28 ha, altitudes varying from 800 to $1,100 \mathrm{~m}$ and it is mainly represented by natural grasslands surrounding Araucaria forest' spots and the peculiar sandstone formations arised. We have found 152 species, distributed in 54 genera, being Asplenium (11 spp.), Blechnum and Thelypteris (10 spp. each), Pecluma, Polypodium and Trichomanes (7 spp. each) the richest genera. One hundred species were found in the forests, 47 in the grasslands and 60 in the sandstone formations. Twentyseven species are restricted to Brazil, of which 14 are endemic to the southeast and south Brazil. Special mention is made to Ctenitis bigarellae Schwartsburd et al., Elaphoglossum langsdorffii (Hook. \& Grev.) T. Moore, Alsophila capensis subsp. polypodioides ( $\mathrm{Sw}$.) Conant and Blechnum australe subsp. auriculatum (Cav.) de la Sota. Identification keys, comments and list of specimens are also presented.
\end{abstract}

Key words: Araucaria forest, Brazilian steppe, devonian steep, sandstone

RESUMO - (Pteridófitas do Parque Estadual de Vila Velha, Ponta Grossa, Paraná, Brasil). Este trabalho apresenta o levantamento das espécies de Pteridófitas do Parque Estadual de Vila Velha, Ponta Grossa, Paraná. O Parque possui uma área de 3.803,28 ha, com altitudes de 800-1.100 m, com predomínio de Campos Gerais entremeados por Capões de Floresta com Araucária, além de afloramentos rochosos areníticos. Foram identificadas 152 espécies distribuídas em 54 gêneros, sendo os mais representativos Asplenium (11 spp.), Blechnum e Thelypteris (10 spp. cada), Pecluma, Polypodium e Trichomanes (7 spp. cada). Cem espécies foram registradas nas florestas, 47 nos campos e 60 nas formações areníticas. Vinte e sete espécies apresentam distribuição restrita ao Brasil, das quais 14 são endêmicas ao Sul e Sudeste. Menção especial para Ctenitis bigarellae Schwartsburd et al., Elaphoglossum langsdorffii (Hook. \& Grev.) T. Moore, Alsophila capensis subsp. polypodioides (Sw.) Conant e Blechnum australe subsp. auriculatum (Cav.) de la Sota. São apresentados chaves de identificação, comentários e materiais selecionados.

Palavras-chave: arenito, campos gerais, escarpa devoniana, floresta com Araucária

\section{Introdução}

A flora de pteridófitas da região sul do Brasil está entre uma das mais bem conhecidas no território nacional, particularmente pelas publicações de Aloísio Sehnem, em virtude dos estudos que geraram a série de publicações da "Flora Ilustrada Catarinense". Em uma série de fascículos, Sehnem apresenta o tratamento taxonômico para várias espécies que, além de Santa Catarina, ocorrem também nos Estados vizinhos, Paraná e Rio Grande do Sul, particularmente nas áreas sob o domínio da Floresta Atlântica s.l.
Para o Paraná, em particular, poucos são os trabalhos efetivamente publicados que envolvem sua diversidade de pteridófitas, entre eles: Hertel (1949), Tessmann (1951), Angely (1963), Dombrowski (1972), Cervi et al. (1987), Cislinski (1996), Dittrich et al. (1999), Kersten \& Silva (2001), Salino (2002), Borgo \& Silva (2003), Bittencourt et al.(2004), Dittrich et al. (2005), Salino et al. (2005) e Schwartsburd et al. (2007). Além destes trabalhos, algumas revisões de gêneros e famílias também contribuem para o conhecimento de sua pteridoflora, uma vez que muitos materiais citados nestes trabalhos são oriundos desse Estado.

1. Universidade Federal do Paraná, Departamento de Botânica, Curso de Pós-graduação em Botânica, Caixa Postal 19031, 81531-980 Curitiba, PR, Brasil

2. Autor para correspondência: pedrophyta@yahoo.com.br 
Para o Parque Estadual de Vila Velha (PEVV), os trabalhos existentes tratam basicamente da flora de angiospermas e gimnospermas, e nenhuma menção acerca das pteridófitas locais é feita (Hatschbach \& Moreira Filho 1972, Takeda \& Farago 2001).

Portanto, o presente trabalho visa contribuir com os estudos sobre as pteridófitas ocorrentes no Estado do Paraná, apresentando um levantamento das espécies de uma importante Unidade de Conservação do Estado.

\section{Material e métodos}

O Parque Estadual de Vila Velha (PEVV) é uma unidade de conservação regida e mantida pelo Governo do Estado do Paraná (Lei ${ }^{\circ} 1.292$, 12-X-1953) e tombado em 1966 pelo Patrimônio Histórico e Artístico Estadual. Localiza-se no Município de Ponta Grossa, segundo planalto paranaense, e compreende uma área de 3.803,28 ha, entre as coordenadas aproximadas de $25^{\circ} 12^{\prime} 20^{\prime \prime}$ $25^{\circ} 15^{\prime} 50^{\prime \prime} \mathrm{S}$ e $49^{\circ} 57^{\prime} 50^{\prime \prime}-50^{\circ} 03^{\prime} 10^{\prime \prime} \mathrm{W}$, com altitudes variando de 800 a $1.100 \mathrm{~m}$.

$\mathrm{Na}$ área do PEVV estão presentes três formações geológicas distintas: Arenito Furnas, Folhelos Ponta Grossa e Arenito Itararé (Bodziak Júnior \& Maack 1946), as quais conferem uma tipologia geológica bastante peculiar que, por meio da ação erosiva de ventos e da chuva, deu origem à várias galerias e afloramentos rochosos distintos, os quais constituem o principal atrativo turístico da região.

De acordo com Wons (1982), o clima ocorrente na região é o Cfb - Clima Subtropical Úmido Mesotérmico (segundo a classificação de Köepen), com média do mês mais quente inferior a $22^{\circ} \mathrm{C}$ e do mês mais frio inferior a $18^{\circ} \mathrm{C}$, sem estação seca definida, porém com médias de umidade menores no período do inverno; o verão é brando e no inverno há a ocorrência frequiente de geadas severas. A temperatura média para os meses mais frios é de $10{ }^{\circ} \mathrm{C} \mathrm{e}$, para os meses mais quentes, de $17^{\circ} \mathrm{C}$, enquanto que a pluviosidade anual está entre 1.300-1.900 mm (IAPAR 1978).

No PEVV, a formação vegetacional dominante são os Campos Gerais, entremeados por "Capões" de Floresta com Araucária, denominados por Veloso et al. (1991) como Estepe (Estepe Arborizada, Estepe Parque e Estepe Gramíneo-lenhosa) e Floresta Ombrófila Mista (Montana e Alto-Montana), respectivamente. Além da vegetação nativa, também encontram-se no Parque matas alteradas com Pinus spp. e Eucalyptus spp.
Foram realizadas várias expedições de coleta ao Parque, no período de setembro de 2003 a março de 2006, quando se procurou percorrer todos os diferentes ambientes do Parque. Além das coletas locais, foram realizadas consultas às coleções dos herbários HUPG, MBM, RB, SP e UPCB.

Neste trabalho optou-se em apresentar o ordenamento taxonômico apenas em nível de gênero, ordenados alfabeticamente, uma vez que algumas famílias importantes de pteridófitas têm sido alvo de vários estudos filogenéticos e, desta forma, com sua circunscrição ainda não claramente definida.

Com vistas à abreviação do "Material selecionado" para o presente estudo, a citação "BRASIL. Paraná: Ponta Grossa, Parque Estadual de Vila Velha" foi suprimida, constando apenas a data, os coletores, e os herbários para onde foram enviadas as duplicatas.

Os autores de espécies foram abreviados segundo Pichi-Sermolli (1996).

Para a análise da distribuição geográfica das espécies estudadas, adotou-se os padrões de distribuição propostos por Parris (2001) e Moran \& Smith (2001), com pequenas modificações, enquadrando as espécies nas seguintes categorias:

1. Circum-Antártica - espécies presentes na América, África e Ásia e/ou Oceania;

2. Atântica - espécies presentes na América, África e eventualmente ilhas do Oceano Atlântico;

3. Pacífica - espécies presentes na América e Ásia e/ou Oceania;

4. Americana - espécies presentes nas Américas do Sul, Central e eventualmente do Norte;

5. Sul-Americana - espécies presentes apenas nos países da América do Sul;

6. Endêmica ao Brasil - espécies presentes apenas no Brasil;

6.1. Endêmica às regiões Sul e Sudeste do Brasil - espécies endêmicas ao Brasil, com distribuição restrita às regiões Sul e Sudeste;

6.1.1. Endêmica ao Paraná - espécies endêmicas ao Estado do Paraná.

Para a análise do ambiente preferencial das espécies foram consideradas as seguintes categorias: 1. Campos secos - espécies encontradas nas regiões de Campos com solo bem drenado.

2. Campos úmidos - espécies encontradas nas regiões de Campos Gerais com drenagem deficiente, formando solos orgânicos e hidromórficos, e também ao redor de córregos. 
3. Floresta com Araucária - espécies encontradas no interior dos Capões de Floresta com Araucária.

4. Formações Areníticas - espécies encontradas especialmente nos paredões e nas galerias formadas pelos afloramentos rochosos.

5. Ambiente ruderal - espécies encontradas em ambientes com acentuada interferência antrópica.

\section{Resultados e Discussão}

Foram registradas 152 espécies de Pteridófitas, distribuídas em 54 gêneros, sendo que os mais representativos foram Asplenium (11 spp.), Blechnum e Thelypteris (10 spp. cada), Pecluma, Polypodium e Trichomanes (7 spp. cada).

Chave para os gêneros de pteridófitas encontrados no PEVV

1. Plantas com microfilos (lâminas uninervadas); esporângios formados nas axilas dorsais dos microfilos

2. Plantas heterosporadas; microfilos ligulados Selaginella

2. Plantas homosporadas; microfilos sem lígula

3. Caule ereto ou pendente, isotomicamente ramificado; as raízes agrupadas em um tufo basal Huperzia

3. Caule principal reptante ou arqueado, com ramificações simples ou anisotômicas; as raízes dispostas ao longo de toda sua extensão

4. Estróbilos pêndulos ou sésseis, ou eretos e terminais sobre ramos simples que surgem dorsalmente sobre o caule Lycopodiella

4. Estróbilos eretos, sésseis ou pedunculados, sobre ramos que surgem dorso-lateralmente sobre o caule

Lycopodium

1. Plantas com megafilos (lâminas multinervadas); esporângios formados na face abaxial ou na margem da lâmina

5. Caule globoso; esporângios unidos em sinângios, liberando os esporos por meio de poros Marattia

5. Caule não globoso; esporângios livres, liberando os esporos através de seu rompimento

6. Esporângios com ânulo rudimentar, lateral, com as células pouco diferenciadas Osmunda

6. Esporângios com ânulo desenvolvido, apical, oblíquo ou vertical, com as células nitidamente diferenciadas

7. Esporângios piriformes e com ânulo apical, presentes exclusivamente no par de pinas proximais modificadas (esporangióforos), não formando soros Anemia

7. Esporângios globosos e com ânulo oblíquo ou vertical, reunidos em soros. Soros formados sobre várias regiões da lâmina, nunca restritos apenas ao par de pinas proximal

8. Esporângios sésseis ou subsésseis; ânulo oblíquo, não interrompido pelo pedicelo

9. Lâmina pseudodicotomicamente dividida, com gemas nas axilas das ramificações; ramos pectinados

10. Caule e gemas das bifurcações exclusivamente com tricomas rijos e avermelhados; nervuras duas ou mais vezes furcadas Dicranopteris

10. Caule e gemas das bifurcações com escamas e eventualmente tricomas laxos e alvacentos; nervuras1-furcadas Sticherus

9. Lâmina simples a várias vezes bilateralmente divida, nunca em padrão dicotômico ou pseudodicotômico, sem gemas nas axilas das ramificações; ramos não pectinados

11. Soros marginais

12. Plantas arborescentes; lâmina com várias camadas de células de espessura, não translúcida, com estômatos

12. Plantas herbáceas; lâmina com 1-2 camadas de células de espessura, translúcida, sem estômatos

13. Indúsio bivalvar Hymenophyllum 13. Indúsio cônico e bilabiado Trichomanes 
11. Soros abaxiais

14. Caule nunca arborescente; plantas exclusivamente com tricomas Lophosoria

14. Caule geralmente arborescente; plantas com escamas e tricomas, as escamas presentes principalmente na base do pecíolo

15. Base do pecíolo com aflébias e escamas com uma ou mais setas nigrescentes

Alsophila

15. Base do pecíolo sem aflébias, com escamas sem setas nigrescentes ... Cyathea

8. Esporângios pedicelados; ânulo vertical, interrompido pelo pedicelo

16. Pecíolo com 2 feixes vasculares na base

17. Lâmina com tricomas unicelulares, aciculares, bifurcados ou estrelados, raramente glabra; soros geralmente arredondados, raramente lineares

18. Lâmina 2-pinado-pinatissecta; costa não sulcada adaxialmente; nervuras secundárias não atingindo a margem do segmento Macrothelypteris

18. Lâmina 1-pinado-pinatífida a 1-pinado-pinatissecta; costa sulcada adaxialmente; nervuras secundárias atingindo a margem do segmento Thelypteris

17. Lâmina glabra ou com tricomas pluricelulares, lineares; soros lineares ou curvos

19. Soros em apenas um lado das nervuras Asplenium

19. Soros pareados dorso com dorso em ambos os lados das nervuras

20. Caule ereto; face adaxial da costa com sulco decorrente ao sulco da raque, glabro

Diplazium

20. Caule reptante; face adaxial da costa com sulco não decorrente ao sulco da raque, com tricomas catenados Deparia

16. Pecíolo com 1, 3 ou mais feixes vasculares na base

21. Frondes articuladas ao caule, sobre filopódios

22. Soros acrosticóides Elaphoglossum

22. Soros arredondados

23. Lâmina simples

24. Nervuras laterais principais definidas, evidentes, oblíquas à costa e paralelas entre si

25. Uma série de soros entre duas nervuras laterais principais adjacentes Niphidium

25. Duas séries de soros entre duas nervuras laterais principais adjacentes Campyloneurum

24. Ausência de nervuras laterais principais definidas e evidentes

26. Frondes dimorfas; escamas do caule não clatradas Microgramma

26. Frondes monomorfas; escamas do caule clatradas .... Campyloneurum 23. Lâmina pinatissecta ou pinada

27. Pecíolo cilíndrico, não canaliculado Pecluma

27. Pecíolo canaliculado

28. Tecido laminar com escamas

29. Lâmina com a base não reduzida e com menos de 15 pares de segmentos Pleopeltis

29. Lâmina gradualmente reduzida na base e com mais de 20 pares de segmentos (ou pinas) Polypodium

28. Tecido laminar sem escamas

30. Nervuras irregularmente anastomosadas; soros dispostos sobre a união de duas ou mais vênulas Phlebodium

30. Nervuras livres ou regularmente anastomosadas tipo gonioflebóide; soros dispostos sobre uma vênula Polypodium 
21. Frondes contínuas com o caule, não formando filopódios

31. Esporos clorofilados

32. Lâmina pinatissecta a 1-pinada; indumento do pecíolo e lâmina formado por setas e tricomas Terpsichore

32. Lâmina simples ou serrulada; pecíolo e lâmina glabros ou com tricomas apenas Cochlidium

31. Esporos não clorofilados

33. Soros marginais ou submarginais

34. Soros lineares

35. Lâmina inteira Vittaria

35. Lâmina dividida de várias formas

36. Lâmina cordada, sagitada, hastada, tri-lobada, palmada ou pedada, porém não verdadeiramente pinada

Doryopteris

36. Lâmina no mínimo 1-pinada

37. Caule revestido apenas por tricomas Pteridium

37. Caule revestido por escamas e eventualmente tricomas

38. Indúsio abaxial presente, abrindo-se em direção à margem da lâmina Lindsaea

38. Indúsio abaxial ausente, soros recobertos pela margem da lâmina modificada em indúsio, e este se abrindo em direção oposta à margem da lâmina

39. Caule ereto ou decumbente; lâmina sem tonalidade glauca na face abaxial Pteris

39. Caule longo-reptante; lâmina com a face abaxial glauca

Histiopteris

34. Soros geralmente arredondados, nunca lineares

40. Caule revestido apenas por tricomas, raramente glabrescente

41. Indúsio duplo, formado por uma porção interna e outra externa Dennstaedtia

41. Indúsio simples, formado apenas pela margem da lâmina recurvada

Hypolepis

40. Caule revestido por escamas e eventualmente tricomas

42. Pseudo-indúsio sem nervuras

Adiantopsis

42. Pseudo-indúsio com nervuras Adiantum

33. Soros abaxiais

43. Soros gimnogramóides ou acrosticóides

44. Soros gimnogramóides

45. Caule com tricomas; cera ausente na face abaxial da lâmina

Eriosorus

45. Caule com escamas; lâmina revestida por cera branca ou amarelada na face abaxial Pityrogramma

44. Soros acrosticóides

46. Lâmina estéril no mínimo 2-pinada Polybotrya

46. Lâmina estéril 1-pinada

47. Caule longo-reptante; nervuras anastomosadas ... Lomagramma 47. Caule curto-reptante; nervuras livres

Olfersia

43. Soros alongados, lineares ou arredondados 
48. Soros lineares, paralelos à costa 49. Lâmina simples Polytaenium

49. Lâmina pinatissecta ou mais dividida Blechnum

48. Soros arredondados ou, se alongados, oblíquos à costa

50. Caule estolonífero, com escamas peltadas; lâmina 1-pinada Nephrolepis

50. Caule não estolonífero, com escamas basifixas; lâmina 1-pinado-pinatífida ou mais dividida

51. Caule reptante

52. Sulcos da raque, raquíola e costa (face adaxial) glabros; escamas do caule com a margem lisa

52. Sulcos da raque, raquíola e costa (face adaxial) com tricomas catenados; escamas do caule com a margem fimbriada e/ou denticulada

Lastreopsis

51. Caule ereto ou decumbente

53. Pínulas dimidiadas; soros alongados Didymochlaena

53. Pínulas ou segmentos não dimidiados; soros arredondados

54. Eixos da lâmina sem tricomas catenados; margem das pínulas com projeções espinulosas Polystichum

54. Eixos da lâmina com tricomas catenados; margem das pínulas ou segmentos sem projeções espinulosas

55. Lâmina geralmente 1-pinadopinatissecta; raque com tricomas catenados com o ápice arredondado ou obtuso; ápice das nervuras secundárias não clavado Ctenitis

55. Lâmina geralmente 2-pinado-pinatissecta ou mais dividida; raque com tricomas catenados com o ápice agudo; ápice das nervuras secundárias clavado

Megalastrum

\section{Adiantopsis Fée}

Chave para as espécies de Adiantopsis encontradas no PEVV

1. Caule ereto; lâmina radialmente pinada A. radiata

1. Caule reptante; lâmina 2-3-pinada

A. chlorophylla

Adiantopsis chlorophylla (Sw.) Fée, Mém. Foug. 5: 145. 1852. Cheilantes chlorophylla Sw., Kongl. Vetensk. Acad. Handl.: 76. 1817.
Materiais selecionados: 11-X-2003, P.H. Labiak \& P.B. Schwartsburd 2960 (SP); 21-VIII-2004, P.B. Schwartsburd et al. 272 (HUPG), 273 (MBM), 274 (HUPG); 23-IV-2005, P.B. Schwartsburd et al. 741 (UPCB); 28-X-2005, P.B. Schwartsburd et al. 940 (COR).

Distribuição: México, Guatemala, Costa Rica, Equador, Peru, Bolívia, Brasil (SE e S), Paraguai, Argentina e Uruguai.

Esta espécie foi comumente encontrada como terrícola nos Campos Gerais e nas bordas de matas alteradas, sendo uma das mais comuns desse bioma. 
Uma das espécies mais semelhantes é Adiantopsis perfasciculata Sehnem, que se distingue principalmente por apresentar o caule ereto, o pecíolo mais escuro e alado por praticamente toda sua extensão, a lâmina menos rija, as pínulas contíguas e os esporos ásperos (Sehnem 1961).

Adiantopsis radiata (L.) Fée, Mém. Foug. 5: 145. 1852. Adiantum radiatum L., Sp. pl.: 1094. 1753.

Material selecionado: 7-I-2004, P.H. Labiak \& P.B. Schwartsburd 3063 (HUPG, MBM, UPCB, SP).

Distribuição: México, Mesoamérica, Antilhas, Trinidad, Colômbia, Venezuela, Guianas, Equador, Peru, Bolívia, Brasil (N, NE, CO, SE, S), Paraguai e Argentina.

Esta espécie foi encontrada como terrícola no interior da Floresta com Araucária.

A forma radial da lâmina a diferencia das demais espécies do gênero, presentes no Brasil.

\section{Adiantum L.}

Chave para as espécies de Adiantum encontradas no PEVV

1. Caule longo-reptante, com as frondes esparsas (mais de $2 \mathrm{~cm}$ distantes entre si) A. pseudotinctum

1. Caule curto a longo-reptante, com as frondes aproximadas (menos de $0,5 \mathrm{~cm}$ distantes entre si) A. raddianum

Adiantum pseudotinctum Hieron., Engl. Bot. Jahrb. 22: 391. 1896.

Material selecionado: 7-I-2005, P.B. Schwartsburd et al. 587 (HUPG, MBM, SP, UPCB).

Distribuição: Brasil (CO, S), Paraguai e Argentina.

Esta espécie foi encontrada como terrícola no interior de Floresta com Araucária.

Ver comentários sob Adiantum raddianum

C. Presl para comparações com esta espécie.

Adiantum raddianum C. Presl, Tent. Pterid.: 158. 1836.

Materiais selecionados: 10-XI-2003, P.B. Schwartsburd 18 (MBM), 24 (UPCB); 10-VI-2004, P.B. Schwartsburd \& F.B. Matos 174 (HUPG); 18-XII-2004, Schwartsburd et al. 480 (HUPG).

Distribuição: México (S), Mesoamérica, Antilhas, Trinidad, Colômbia, Venezuela, Equador, Peru, Bolívia,
Brasil (CO, SE e S), Paraguai, Chile, Argentina e Uruguai.

Popularmente conhecida como Avenca (assim com várias outras espécies de Adiantum), esta espécie foi encontrada como terrícola e rupícola no interior da Floresta com Araucária, borda e interior das matas alteradas, ambientes ruderais e até mesmo nos Campos. Porém, parece estar exclusivamente associada a microhábitats úmidos, como barrancos ou rochas próximas a riachos. Segundo Prado (2004a) esta espécie é cultivada no mundo inteiro, como planta ornamental.

Adiantum raddianum assemelha-se a A. pseudotinctum principalmente pela forma dos segmentos (assimetricamente incisos, com lobos arredondados e nervação flabeliforme), porém, podem ser distinguidas, além das características apresentadas na chave, pelo fato de A. raddianum apresentar o caule com as bases dos pecíolos persistentes e em A. pseudotinctum esta característica está ausente. Outras espécies semelhantes a $A$. raddianum são A. poiretii Wikstr., a qual difere pelos segmentos comumente com a base arredondada e caule estolonífero, e A. lorentzii Hieron., que difere pelos últimos segmentos profundamente incisos, formando lobos lineares.

Alsophila R. Br.

Chave para as espécies de Alsophila encontradas no PEVV

1. Plantas rupícolas; caule subarborescente, com até $20 \mathrm{~cm}$ compr.; aflébias sem expansões laminares; nervuras secundárias simples

A. capensis subsp. polypodioides

1. Plantas terrícolas; caule arborescente, com até $10 \mathrm{~m}$ compr.; aflébias com expansões laminares; nervuras secundárias furcadas.... A. setosa

Alsophila capensis (L. f.) J. Sm. subsp. polypodioides (Sw.) Conant, J. Arnold Arbor. 64(3): 369. 1983. Cyathea polypodioides Sw., Kongl. Vetensk. Acad. Handl.: 78. 1817.

Materiais selecionados: 4-X-1963, G.G. Hatschbach 10222 (MBM); 6-III-2005, P.B. Schwartsburd et al. 673 (PACA), 674 (BHCB, UPCB); 21-IV-2005, P.B. Schwartsburd et al. 710 (HUPG), 711 (UPCB), 712 (MBM, RB). 
Distribuição: Endêmica das regiões Sul e Sudeste do Brasil.

Esta subespécie aparenta ter hábito e hábitat muito específicos, tendo sido encontrada exclusivamente como rupícola nos paredões das galerias das Formações Areníticas, em ambientes permanentemente sombreados e muito úmidos.

Segundo Conant (1983 apud Fernandes 1997), as duas subespécies desta espécie são separadas geograficamente: a presente ocorrendo no Sul e Sudeste do Brasil, e Alsophila capensis subsp. capensis no Sudeste da África, sendo a única espécie do gênero presente em ambos os continentes (Moran $\&$ Smith 2001). Estes autores ainda citam A. capensis subsp. capensis para África Austral, Madagascar, Ceilão, Malásia e Java.

Segundo Fernandes (1997), esta subespécie é encontrada no Brasil geralmente em altitudes maiores que $1.000 \mathrm{~m}$, com exceção de uma coleta no Rio Grande do Sul a $120 \mathrm{~m}$.

Alsophila setosa Kaulf., Enum. fil.: 249. 1824.

Materiais selecionados: 7-I-2004, P.H. Labiak \& P.B. Schwartsburd 3053 (SP), 3081 (UPCB), 3082 (COR), 3083 (MBM), 3095 (HUPG); 5-IV-2004, P.B. Schwartsburd \& M. Nogueira Júnior 96 (HUPG); 21-VIII-2004, P.B. Schwartsburd et al. 312 (HUPG, MBM, UPCB).

Distribuição: Bolívia, Brasil (SE e S), Paraguai e Argentina.

Esta espécie foi encontrada como terrícola no interior da Floresta com Araucária, principalmente próxima às nascentes d'água, onde forma grandes populações. Freqüentemente sobre seu caule se desenvolvem várias espécies de epífitas, destacando-se entre elas Pecluma truncorum (Lindm.) M.G. Price, que parece ter uma associação bastante intrínseca com essa espécie (ver comentários desta espécie).

Anemia Sw., nom. cons.

Chave para as espécies de Anemia encontradas no PEVV

1. Lâmina 1-pinada (raramente o segundo par de pinas proximal mais dividido), com o ápice conforme; nervuras anastomosadas .....................A. phyllitidis

1. Lâmina 2-pinada a 2-pinadopinatissecta, com o ápice pinatissecto; nervuras livres
2. Caule longo-reptante, delgado, horizontal, com tricomas pardoalaranjados A. tomentosa

2. Caule curto-reptante, compacto, subereto (ascendente na região de onde partem as frondes), com tricomas vermelho-alaranjados ...A. raddiana

Anemia phyllitidis (L.) Sw., Syn. fil.: 155. 1806. Osmunda phyllitidis L., Sp. pl.: 1064. 1753.

Materiais selecionados: 10-VI-2004, P.B. Schwartsburd \& F.B. Matos 210 (UPCB); 20-XII-2004, P.B. Schwartsburd \& P. Ambrósio 518 (SP); 7-I-2005, P.B. Schwartsburd et al. 588 (HUPG, UPCB); 22-IV-2005, P.B. Schwartsburd et al. 731 (MBM, RB, UPCB).

Distribuição: México, Mesoamérica, Grandes Antilhas, Colômbia, Venezuela, Guiana, Suriname, Equador, Peru, Bolívia, Brasil (NE, CO, SE e S), Paraguai, Argentina e Uruguai.

Esta espécie foi encontrada como terrícola no interior da Floresta com Araucária, matas alteradas com Pinus spp., com Eucalyptus spp. e matas ciliares.

O material examinado apresenta uma alta variação morfológica, principalmente quanto às dimensões do pecíolo, lâmina, pinas, esporangióforos e grau de pilosidade do pecíolo e da lâmina. Como tais variações não aparentam serem estáveis e diferenciais, e se apresentam como um gradiente, optou-se em considerar apenas um táxon com uma grande plasticidade fenotípica.

Anemia raddiana Link, Hort. Berol. 2: 144. 1833.

Materiais selecionados: 10-VI-2004, P.B. Schwartsburd \& F.B. Matos 211 (COR); 22-IV-2005, P.B. Schwartsburd et al. 726 (UPCB); 16-V-2005, P.B. Schwartsburd \& M. Nogueira Júnior 806 (HUPG); 17-V-2005, P.B. Schwartsburd \& M. Nogueira Júnior 814 (MBM, UPCB), 815 (HUPG, RB, SP).

Distribuição: Endêmica às regiões Sul e Sudeste do Brasil.

Esta espécie foi encontrada como terrícola nos Campos Gerais e também no interior de matas alteradas com Eucalyptus spp.

Uma das espécies mais semelhantes é Anemia flexuosa (Savigny) Sw. que, segundo Mickel (1962), apresenta os esporangióforos menores que o comprimento da lâmina estéril, enquanto que Anemia 
raddiana apresenta os esporangióforos geralmente maiores que a lâmina estéril.

Anemia tomentosa (Savigny) Sw., Syn. fil.: 157. 1806. Osmunda tomentosa Savigny in Lam., Enc. 4: 652.1797

Materiais selecionados: 19-X-2005, P.B. Schwartsburd et al. 934 (UPCB); 5-III-2006, P.B. Schwartsburd et al. 1002 (HUPG, MBM, UPCB).

Distribuição: México, Bolívia, Brasil (N, NE, CO, SE e S), Paraguai, Argentina e Uruguai.

Esta espécie foi encontrada como terrícola nos Campos Gerais, em áreas secas e matas ciliares.

\section{Asplenium L.}

Chave para as espécies de Asplenium encontradas no PEVV

1. Caule longo-reptante

2. Caule densamente coberto por escamas lineares; lâmina cartácea a subcoriácea A. incurvatum

2. Caule glabro ou com escamas lanceoladas esparsas; lâmina membranácea A. triquetrum

1. Caule ereto ou decumbente

3. Raque com gemas prolíferas

4. Lâmina 1 a 3-pinada; raque prolongada, com a gema prolífera distante das pinas distais

A. radicans

4. Lâmina exclusivamente 1-pinada; raque não prolongada, com a gema prolífera logo acima das pinas distais

A. kunzeanum

3. Raque sem gemas prolíferas

5. Lâmina 2 ou mais vezes pinada

6. Caule com escamas lineares; frondes pendentes

A. scandicinum

6. Caule com escamas lanceoladas; frondes eretas

7. Pecíolo e raque atropurpúreos; lâmina membranácea A. pseudonitidum

7. Pecíolo preto, fosco, tornando-se acinzentado na raque; lâmina cartácea .

A. gastonis

5. Lâmina 1-pinada

8. Lâmina não reduzida na base, com menos de 20 pares de pinas

9. Pinas proximais desprovidas de aurículas; pinas medianas com ápice acuminado

A. abscissum

9. Pinas proximais com aurículas na base (lado acroscópico); pinas medianas com ápice obtuso

A. inaequilaterale

8. Lâmina gradualmente reduzida na base, com mais de 25 (geralmente muito mais)

pares de pinas

10. Lâmina verde-clara quando seca; pecíolo e raque negros; pinas medianas com $3 \mathrm{~cm}$ compr. ou maiores

A. harpeodes

10. Lâmina verde-escura quando seca; pecíolo e raque castanhos; pinas medianas raramente ultrapassando $2 \mathrm{~cm}$ compr.

A. claussenii

Asplenium abscissum Willd., Sp. pl. 5(1): 321. 1810.

Material selecionado: 21-IV-2005, P.B. Schwartsburd et al. 714 (MBM, UPCB).

Distribuição: E.U.A. (S), México, Mesoamérica, Pequenas Antilhas, Trinidad, Tobago, Colômbia, Venezuela, Suriname, Equador, Peru, Bolívia, Brasil (N, NE, CO, SE e S), Paraguai, Argentina e Uruguai.
Esta espécie foi raramente encontrada no PEVV, ocorrendo como terrícola no interior da Floresta com Araucária.

Asplenium hostmanii Hieron. e A. cruegeri Hieron. são espécies semelhantes a Asplenium abscissum, podendo ser distinguidas por apresentar a lâmina membranácea, variando de lanceolada a oblonga, enquanto que A. abscissum apresenta a lâmina cartácea e deltóide (Sylvestre 2001). 
Asplenium claussenii Hieron., Hedwigia 60: 241. 1918.

Materiais selecionados: 22-XII-2000, S. Dala Rosa 132 (UPCB); 11-X-2003, P.H. Labiak \& P.B. Schwartsburd 2963 (UPCB); 11-X-2003, P.H. Labiak \& P.B. Schwartsburd 2978 (RB); 10-XI-2003, P.B. Schwartsburd 36 (HUPG), 37 (SP), 38 (UPCB), 39 (RB); 15-XII-2003, P.B. Schwartsburd \& A.C. Hatschbach 63 (UPCB), 64 (UPCB), 71 (COR); 7-I-2005, P.B. Schwartsburd et al. 585 (RB); 29-X-2005, P.B. Schwartsburd et al. 958 (RB), 959 (MBM).

Distribuição: Grandes Antilhas, Venezuela, Peru, Bolívia, Brasil (NE, CO, SE e S), Paraguai, Argentina e Uruguai.

Esta espécie foi encontrada como terrícola, rupícola e epífita acidental, no interior da Floresta com Araucária e nas Formações Areníticas.

Os materiais Dala Rosa 132, Labiak \& P.B. Schwartsburd 2963 e 2978, Schwartsburd \& Hatschbach 63, Schwartsburd et al. 585, 958 e 959 diferem um pouco da forma básica dos outros materiais de $A$. claussenii, por apresentarem as pinas com a margem um pouco mais crenada, ápice da lâmina não caudado-alongado e maior número de nervuras no lado basiscópico das pinas.

Asplenium gastonis Fée, Crypt. Vasc. Brés. 1: 70. 1869.

Materiais selecionados: 17-VIII-2000, F.M. Ramos et al. 5 (UPCB); 11-X-2003, P.H. Labiak \& P.B. Schwartsburd 2970 (RB, UPCB); 10-VI-2004, P.B. Schwartsburd \& F.B. Matos 214 (MBM), 194 (SP); 21-VIII-2004, P.B. Schwartsburd et al. 268 (HUPG).

Distribuição: Brasil (SE e S), Paraguai, Argentina e Uruguai.

Esta espécie foi encontrada preferencialmente como terrícola, embora também encontrada como epífita acidental e rupícola, em locais com grande acúmulo de húmus, principalmente na Floresta com Araucária e nas Formações Areníticas.

Segundo Sylvestre (2001) a espécie mais semelhante é Asplenium cuspidatum Lam., que pode ser diferenciada por apresentar a lâmina coriácea, com a presença de pínulas pecioluladas apenas no terço inferior da lâmina.

Asplenium harpeodes Kunze, Linnaea 18: 329. 1844.

Materiais selecionados: 11-X-2003, P.H. Labiak \&
P.B. Schwartsburd 2980 (HUPG); 21-VIII-2004, P.B. Schwartsburd et al. 308 (MBM); 29-X-2005, P.B. Schwartsburd et al. 960 (UPCB).

Distribuição: México (S), Mesoamérica, Grandes Antilhas, Colômbia, Venezuela, Guiana, Guiana Francesa, Equador, Peru, Bolívia e Brasil (SE e S).

Esta espécie foi encontrada como epífita no interior da Floresta com Araucária, principalmente em regiões adjacentes a córregos, e especialmente sobre indivíduos de Pteridófitas arborescentes (Cyathea spp. e Alsophila setosa).

Asplenium harpeodes pode ser facilmente distingüida das demais espécies congenéricas, que apresentam o mesmo formato de pinas (rômbico com a base inequilateral), pela notável lâmina verde-clara contrastando com o pecíolo e raque negros e brilhantes.

Asplenium inaequilaterale Willd. in L., Sp. pl. ed. 4, 5: 322.1810.

Material selecionado: 14-XII-2004, P.B. Schwartsburd \& F.B. Matos 446 (MBM, UPCB).

Distribuição: Ásia (S) e África (E); Bolívia, Brasil (NE, CO, SE e S), Paraguai, Argentina e Uruguai.

Esta espécie foi encontrada como rupícola às margens de riachos, no interior da Floresta com Araucária.

Asplenium incurvatum Fée, Crypt. Vasc. Brés. 1: 69. 1869.

Materiais selecionados: 10-XI-2003, P.B. Schwartsburd 33 (COR, UPCB); 21-VIII-2004, P.B. Schwartsburd et al. 226 (MBM), 265 (RB), 284 (HUPG); 21-IV-2005, P.B. Schwartsburd et al. 721 (UPCB); 15-V-2005, P.B. Schwartsburd \& M. Nogueira Júnior 782 (MBM).

Distribuição: Endêmica às regiões Sul e Sudeste do Brasil.

Esta espécie foi encontrada como terrícola ou rupícola, algumas vezes também sobre troncos em decomposição, no interior da Floresta com Araucária e nas Formações Areníticas.

As espécies mais semelhantes são Asplenium serra L. e A. campos-portoi Brade, as quais podem ser distingüidas por apresentar as escamas do caule lanceoladas a oval-lanceoladas, castanhas, com o ápice brevemente acuminado (Sylvestre 2001).

Asplenium kunzeanum Klotzsch ex Rosenst., Hedwigia 46: 100. 1906. 
Materiais selecionados: 11-X-2003, P.H. Labiak \& P.B. Schwartsburd 2981 (RB); 21-VIII-2004, P.B. Schwartsburd et al. 320 (MBM, UPCB).

Distribuição: Endêmica ao Brasil (NE, SE e S).

Esta espécie foi encontrada como terrícola às margens de riachos, no interior da Floresta com Araucária.

A presença de gemas no ápice das frondes é uma das características marcantes desta espécie.

Asplenium pseudonitidum Raddi, Pl. Bras. Nov. Gen. 1: 39. 1825.

Materiais selecionados: 11-X-2003, P.H. Labiak \& P.B. Schwartsburd 2971 (UPCB, RB); 15-XII-2003, P.B. Schwartsburd \& A.C. Hatschbach 59 (SP); 21-VIII-2004, P.B. Schwartsburd et al. 258 (HUPG), 296 (MBM, UPCB).

Distribuição: Endêmica às regiões Sul e Sudeste do Brasil.

Esta espécie foi encontrada como terrícola e epífita sobre troncos em decomposição, no interior da Floresta com Araucária.

Asplenium radicans L., Syst. Nat. ed. 10, 2: 1323. 1759.

Materiais selecionados: 15-IV-1992, J. Cislinski et al. 139 (UPCB); 7-I-2004, P.H. Labiak \& P.B. Schwartsburd 3069 (HUPG, RB, SP, UPCB); 21-VIII-2004, P.B. Schwartsburd et al. 301 (HUPG, MBM), 303 (UPCB); 14-XII-2004, P.B. Schwartsburd \& F.B. Matos 451 (UPCB), 455 (UPCB); 6-III-2005, P.B. Schwartsburd et al. 670 (HUPG, MBM); 19-X-2005, P.B. Schwartsburd et al. 924 (HUPG, MBM).

Distribuição: México (S), Mesoamérica, Grandes Antilhas, Colômbia, Venezuela, Guiana, Peru, Bolívia e Brasil (N, CO, SE e S).

Esta espécie foi encontrada como rupícola no interior da Floresta com Araucária e nas Formações Areníticas, especialmente em locais onde o solo é rochoso e com acúmulo de húmus.

Tradicionalmente são reconhecidas quatro variedades para esta espécie, separadas de acordo com o grau de dissecção da lâmina: Asplenium radicans var. cirrhatum (Rich. ex Willd) Rosenst., lâmina 1-pinada; A. radicans var. radicans C.V. Morton \& Lellinger, lâmina 2-pinada; $A$. radicans var. partitum (Klotzsch) Hieron., lâmina 3-pinada, com as pínulas contendo 3 segmentos; e A. radicans var. uniseriale (Raddi) L.D. Gómez, lâmina 3-pinada, com as pínulas contendo 5 a 9 segmentos (Sylvestre 2001). Das quatro variedades, as três que possuem as lâminas mais decompostas são citadas para o Parque Estadual de Vila Velha, em Sylvestre (2001), e também foram encontradas no presente estudo. Tendo em vista a grande sobreposição dos caracteres utilizados para se distinguir essas variedades, observada nos espécimes analisados, optou-se em manter apenas o nível de espécie para os materiais do PEVV.

Asplenium scandicinum Kaulf., Enum. fil.: 177. 1824.

Materiais selecionados: 15-XII-2003, P.B. Schwartsburd \& A.C. Hatschbach 60 (UPCB); 21-VIII-2004, P.B. Schwartsburd et al. 257 (MBM); 29-X-2005, P.B. Schwartsburd et al. 966 (RB).

Distribuição: Brasil (SE e S) e Argentina.

Esta espécie foi encontrada exclusivamente como epífita pendente, no interior da Floresta com Araucária.

É uma espécie facilmente reconhecida pelo padrão de divisão da lâmina até 4-pinnado-pinatissecta, pela consistência membranácea, pela ausência de tricomas e/ou escamas na raque e tecido laminar, além da coloração do pecíolo, que tende a passar de castanho a verde na proximidade com a raque.

Asplenium triquetrum N. Murak. \& R.C. Moran, Ann. Mo. Bot. Gard. 80(1): 31. 1993.

Material selecionado: 21-VIII-2004, P.B. Schwartsburd et al. 313 (UPCB).

Distribuição Geográfica: Bolívia, Brasil (SE e S), Paraguai e Argentina.

Esta espécie é de ocorrência rara no Parque. Foi encontrada como rupícola às margens de riachos, no interior da Floresta com Araucária.

Asplenium laetum $\mathrm{Sw}$. é uma das espécies mais semelhantes, podendo ser distinguida por apresentar a pina apical pinatífida e base acroscópica das pinas não auriculadas (Sylvestre 2001). 


\section{Blechnum L.}

Chave para as espécies de Blechnum encontradas no PEVV

1. Frondes monomorfas ou hemidimorfas (com as pinas distais férteis, mais estreitas que as estéreis, clorofiladas)

2. Caule ereto, arborescente; escamas da base do pecíolo lineares, negras, com mais de $2,5 \mathrm{~cm}$ compr.

B. brasiliense

2. Caule ereto ou reptante, não arborescente; escamas da base do pecíolo deltóides ou lanceoladas, marrom concolores ou bicolores (marrom com a porção central nigrescente), com menos de $1,5 \mathrm{~cm}$ compr.

3. Frondes hemidimorfas; lâmina com projeções espinulosas na base e no ápice das pinas, eventualmente ao longo da margem B. australe subsp. auriculatum

3. Frondes monomorfas; lâmina sem projeções espinulosas ou com projeções restritas ao ápice das pinas

4. Tricomas presentes no tecido laminar e margem da lâmina; raque com tricomas pluricelulares B. laevigatum

4. Tricomas ausentes no tecido laminar e margem da lâmina; raque com tricomas unicelulares e/ou glandulares

5. Lâmina lanceolada ou oval-lanceolada, base truncada, não reduzida (ou com o par de pinas proximal levemente menor que os acima)

B. austrobrasilianum

5. Lâmina linear ou linear-lanceolada, base gradualmente reduzida

6. Lâmina fértil com menos de $2 \mathrm{~cm}$ larg.; relação comprimento/largura das pinas medianas menor ou igual a 1,5 B. asplenioides

6. Lâmina fértil com mais de $3 \mathrm{~cm}$ de larg.; relação comprimento/largura das pinas medianas maior que 2 B. polypodioides

1. Frondes dimorfas (pinas férteis aclorofiladas)

7. Base do pecíolo com escamas concolores

8. Lâmina não reduzida na base, as pinas basais maiores ou iguais em tamanho às medianas; pinas medianas pecioluladas ou sésseis B. cordatum

8. Lâmina abruptamente reduzida na base, as pinas basais auriculiformes, muito menores que as medianas; pinas medianas totalmente adnadas B. divergens

7. Base do pecíolo com escamas bicolores

9. Caule arborescente; pinas medianas pecioluladas ou sésseis

9. Caule escandente; pinas medianas totalmente adnadas B. schomburgkii $B$. binervatum subsp. acutum

Blechnum asplenioides Sw., Kongl. Vetensk. Acad. Handl.: 72. 1817.

Material selecionado: 19-X-2005, P.B. Schwartsburd et al. 927 (HUPG, MBM, UPCB).

Distribuição: Colômbia, Venezuela, Guiana, Suriname, Peru, Bolívia, Brasil (N, CO, SE e S), Paraguai e Argentina.

Esta espécie foi raramente encontrada no PEVV, ocorrendo como rupícola nas Formações Areníticas e em frestas de rochas de cachoeiras dos Campos Gerais.

Dentre as espécies ocorrentes no Parque, Blechnum laevigatum também pode apresentar frondes férteis com menos de $2 \mathrm{~cm}$ de larg., porém, difere de $B$. asplenioides pela lâmina pubescente em todas as regiões (eixos, tecido laminar e margem).

Blechnum australe L. subsp. auriculatum (Cav.) de la Sota, Bol. Soc. Argent. Bot. 14: 178. 1972. Blechnum auriculatum Cav., Descr. P1. (Cavanilles) 262. 1802.

Material selecionado: 15-XII-2003, P.B. Schwartsburd \& A.C. Hatschbach 52 (HRCB, MBM, UPCB).

Distribuição: Brasil (S), Argentina e Uruguai. Esta espécie foi raramente encontrada no PEVV, 
ocorrendo como terrícola no interior da Floresta com Araucária.

Alguns autores (e.g. Legrand \& Lombardo 1958, Sehnem 1968) consideram o status de espécie para os exemplares americanos: Blechnum auriculatum Cav. Porém, outros autores (e.g. Parris 2001, Dittrich 2005 ) consideram esta uma subespécie de $B$. australe L. Segundo Dittrich (2005), B. australe subsp. auriculatum ocorre na América, e B. australe subsp. australe no Sul da África.

Dittrich (2005) afirma que esta subespécie é "comum no Rio Grande do Sul, incomum em Santa Catarina, rara no Paraná e ausente de São Paulo para o norte". De acordo com este autor, Sehnem (1968) e pesquisa nos herbários HUPG, MBM e UPCB, há apenas três registros desta subespécie para o Paraná: Guarapuava, Hatschbach \& Guimarães 20495 (MBM, PACA, UPCB); Candói, Schwartsburd et al. s.n. (UPCB 54422); e o material supracitado. Sendo estes os limites setentrionais de distribuição deste táxon, conhecidos até o momento.

Blechnum austrobrasilianum de la Sota, Bol. Soc. Arg. Bot. 16(3): 248. 1975.

Materiais selecionados: 15-XII-2003, P.B. Schwartsburd \& A.C. Hatschbach 70 (MBM), 53 (HRCB, SP); 6-IV-2004, P.B. Schwartsburd \& M. Nogueira Júnior 110 (UPCB), 111 (RB); 10-VI-2004, P.B. Schwartsburd \& F.B. Matos 191 (HUPG).

Distribuição: Bolívia, Brasil (CO, SE e S) e Argentina (NE e NO).

Esta espécie foi encontrada como terrícola e rupícola, no interior das Formações Areníticas, Floresta com Araucária e em matas alteradas com Pinus spp., geralmente ocorrendo em grandes populações, com muitos fascículos de frondes conectados por estolões.

$O$ presente material enquadra-se no que tradicionalmente vinha se classificando como Blechnum glandulosum Kaulf. sensu Sehnem (1968), porém resolveu-se aceitar o conceito sugerido por Dittrich (2005).

Blechnum binervatum (Poir.) C.V. Morton \& Lellinger subsp. acutum (Desv.) R.M. Tryon \& Stolze, Fieldiana Bot. 32: 64. 1993. Lomaria acuta Desv., Mém. Soc. Linn. Paris 6: 290. 1827.

Materiais selecionados: 10-XI-2003, P.B. Schwartsburd 31 (HRCB, SP); 7-I-2004, P.H.
Labiak \& P.B. Schwartsburd 3049 (HRCB, HUPG); 10-VI-2004, P.B. Schwartsburd \& F.B. Matos 176 (HUPG); 21-XII-2004, P.B. Schwartsburd \& T. Takeuchi 545 (MBM, UPCB); 28-X-2005, P.B. Schwartsburd et. al. 941 (RB).

Distribuição: México (S), Mesoamérica, Antilhas, Colômbia, Venezuela, Bolívia, Brasil (SE e S), Paraguai e Argentina.

Esta espécie foi encontrada como terrícola, rupícola e hemi-epífita, tanto no interior das Formações Areníticas e Floresta com Araucária, como em matas ciliares dos Campos Gerais.

Segundo Tryon \& Stolze (1993) e Dittrich (2005), esta espécie ocorre desde o Sul do México até a Bolívia, Argentina e Sul do Brasil, estando separada em três subespécies. De acordo com as diferenças consideradas entre as subespécies, por Tryon \& Stolze (1993), o presente material se enquadra perfeitamente nas características citadas para Blechnum binervatum subsp. acutum, a saber: lâmina com mais de $10 \mathrm{~cm}$ larg., abruptamente reduzida na base, pinas espaçadas com o sinus largo, e escamas do caule (e/ou base do pecíolo) com a margem não denteada.

Blechnum brasiliense Desv., Ges. Naturf. Freunde Berlin Mag. Neusten Entdeck. Gesammten Naturk. 5: 330. 1811.

Materiais selecionados: 7-I-2004, P.H. Labiak \& P.B. Schwartsburd 3092 (HRCB, HUPG, UPCB); 10VI-2004, P.B. Schwartsburd \& F.B. Matos 173 (MBM).

Distribuição: Guatemala, Colômbia, Venezuela, Equador, Peru, Bolívia, Brasil (NE, CO, SE e S), Paraguai, Argentina e Uruguai.

Esta espécie foi comumente encontrada no PEVV, principalmente como terrícola no interior da Floresta com Araucária, próxima a riachos ou nascente d'água; mas também encontrada em áreas de campo.

Blechnum cordatum (Desv.) Hieron., Hedwigia 47: 239. 1908. Lomaria cordata Desv., Ges. Naturf. Freunde Berlin Mag. Neuesten Entdeck. Gesammten Naturk. 5: 330. 1811.

Materiais selecionados: 19-XII-2004, P.B. Schwartsburd et al. 506 (SP, UPCB); 16-V-2005, P.B. Schwartsburd \& M. Nogueira Júnior 795 (MBM); 17-V-2005, P.B. Schwartsburd \& M. Nogueira Júmior 820 (UPCB).

Distribuição: Colômbia,Venezuela, Equador, Peru, 
Bolívia, Brasil (CO, SE e S), Paraguai, Chile (incluindo Ilhas Juan Fernández) e Argentina (Malvinas).

Esta espécie foi encontrada como terrícola tanto nos Campos Gerais como no interior da Floresta com Araucária, mas geralmente associada a ambientes úmidos (banhados e matas ciliares).

O material analisado apresenta um altíssimo grau de variação morfológica, principalmente quanto à orientação do caule, tamanho das frondes em indivíduos férteis (com menos de $50 \mathrm{~cm}$ a mais de $1 \mathrm{~m}$ compr.), tamanho e forma das pinas (lineares a linear-oblongas, ápice agudo a obtuso), e densidade do indumento. Tais características têm sido frequentemente utilizadas para separar várias espécies deste complexo como, por exemplo, a circunscrição específica adotada por Sehnem (1968). Como a circunscrição deste autor não se mostrou funcional para o material do PEVV, optou-se em denominá-lo todo como Blechnum cordatum s.l., assim como sugerido por Dittrich (2005).

Blechnum divergens (Kunze) Mett., Ann. Sci. Nat. Bot. sér. 5, 2: 225. 1864. Lomaria divergens Kunze, Linnaea 9: 57.1834.

Materiais selecionados: 6-III-2005, P.B. Schwartsburd et al. 665 (HUPG, SP), 666 (MBM, UPCB), 667 (BHCB, RB).

Distribuição: México, Mesoamérica, Antilhas, Colômbia, Venezuela, Equador, Peru, Bolívia e Brasil (SE e $\mathrm{S})$.

Esta espécie foi encontrada exclusivamente como rupícola nas Formações Areníticas, especialmente em ambientes muito úmidos, próximo a nascentes d'água. Neste micro-habitat também é comum a ocorrência de Alsophila capensis subsp. polypodioides e Ctenitis bigarellae.

Blechnum laevigatum Cav., Descr. P1.: 263. 1802.

Materiais selecionados: 10-XI-2003, P.B. Schwartsburd 47 (MBM, RB); 7-I-2004, P.H. Labiak \& P.B. Schwartsburd 3066 (SP, UPCB); 5-III-2005, P.B. Schwartsburd et al. 657 (HUPG).

Distribuição: Bolívia, Brasil (CO e S), Argentina e Uruguai.

Esta espécie foi encontrada preferencialmente como rupícola nas Formações Areníticas, porém também foram encontrados indivíduos terrícolas no interior da Floresta com Araucária, próximos a riachos.

Blechnum laevigatum apresenta como característica distintiva, em relação às outras espécies de Blechnum ocorrentes no PEVV, a presença de tricomas pluricelulares e lineares sobre o pecíolo, raque, costa, nervuras, tecido laminar e margem da lâmina.

Blechnum polypodioides Raddi, Opusc. Sci. Bol. 3: 294. 1819.

Materiais selecionados: 10-XI-2003, P.B. Schwartsburd 6 (HRCB, MBM, UPCB); 7-I-2004, P.H. Labiak \& P.B. Schwartsburd 3070 (UPCB); 10-VI-2004, P.B. Schwartsburd \& F.B. Matos 234 (SP), 235 (HUPG); 14-XII-2004, P.B. Schwartsburd \& F.B. Matos 464 (RB); 21-XII-2004, P.B. Schwartsburd \& T. Takeuchi 549 (MBM).

Distribuição: México, Mesoamérica, Antilhas, Trinidad, Colômbia, Venezuela, Guiana, Suriname, Equador, Peru, Bolívia, Brasil (Ilha da Trindade, CO, SE e S), Paraguai e Argentina.

Esta espécie foi encontrada preferencialmente como rupícola nas Formações Areníticas e no interior das Furnas, raramente encontrada como terrícola.

Blechnum schomburgkii (Klotzsch) C. Chr., Ind. fil.: 159. 1905. Lomaria schomburgkii Klotzsch, Linnaea 20: 346. 1847.

Materiais selecionados: 7-I-2004, P.H. Labiak \& P.B. Schwartsburd 3057 (HRCB, HUPG, UPCB); 10-VI-2004, P.B. Schwartsburd \& F.B. Matos 184 (MBM, UPCB); 21-VIII-2004, P.B. Schwartsburd et al. 288 (HUPG); 21-XII-2004, P.B. Schwartsburd \& T. Takeuchi 541 (MBM); 22-XII-2004, P.B. Schwartsburd \& T. Takeuchi 555 (RB).

Distribuição: Venezuela, Guiana, Peru, Bolívia, Brasil (NE, CO, SE e S) e Uruguai.

Esta espécie foi comumente encontrada no PEVV, sendo um dos principais elementos pteridofíticos dos Campos Gerais, ocorrendo como terrícola tanto de áreas úmidas como secas.

Blechnum schomburgkii apresenta resistência à queimadas; foram visualizados vários caules arborescentes queimados com novas frondes verdes se desenvolvendo. 
Campyloneurum C. Presl

Chave para as espécies de Campyloneurum encontradas no PEVV

1. Lâmina com menos de $1,3 \mathrm{~cm}$ larg., não formando nervuras laterais principais, com pontuações brancas na face adaxial C. austrobrasilianum

1. Lâmina com mais de $1,6 \mathrm{~cm}$ larg., formando nervuras laterais principais definidas, evidentes e paralelas entre si, sem pontuações brancas na face adaxial

2. Caule delgado e longo-reptante; pecíolo maior que $1 / 5$ do tamanho da lâmina; lâmina membranácea ..... C. minus

2. Caule compacto e curto-reptante; pecíolo menor que $1 / 6$ do tamanho da lâmina (geralmente muito menor); lâmina coriácea C. nitidum

Campyloneurum austrobrasilianum (Alston) de la Sota, Opera Lillo. 5: 99. 1960. Polypodium austrobrasilianum Alston, J. Bot. 77: 347. 1939.

Materiais selecionados: 8-IX-2000, S. Dala Rosa 120 (UPCB); 11-X-2003, P.H. Labiak \& P.B. Schwartsburd 2977 (UPCB); 15-XII-2003, P.B. Schwartsburd \& A.C. Hatschbach 65 (MBM); 5-IV-2004, P.B. Schwartsburd \& M. Nogueira Júnior 87 (HUPG); 10-VI-2004, P.B. Schwartsburd \& F.B. Matos 202 (COR).

Distribuição: Endêmica ao Brasil (CO, SE e S).

Esta espécie foi encontrada como epífita no interior da Floresta com Araucária, e também como rupícola nas Formações Areníticas.

Campyloneurum aglaolepis (Alston) de la Sota é uma das espécies mais semelhantes, sendo distinguida por apresentar as escamas do caule estreitamente oblongas, variando de (4,5-) 6-10 mm compr. e (1-)1,5-2,5 mm larg.; em oposição, $C$. austrobrasilianum apresenta as escamas oblongas, com até 5 mm compr. e $1 \mathrm{~mm}$ larg. (León 1992).

Campyloneurum minus Fée, Gen. fil.: 258. 1852.

Materiais selecionados: 21-VIII-2004, P.B. Schwartsburd et al. 311 (UPCB), 314 (HUPG, MBM).
Distribuição: Brasil (SE e S), Paraguai e Argentina.

Esta espécie foi raramente encontrada no PEVV, ocorrendo como rupícola às margens de riachos, no interior da Floresta com Araucária.

Campyloneurum nitidum (Kaulf.) C. Presl, Tent. Pterid.: 190. 1836. Polypodium nitidum Kaulf., Enum. fil.: 92. 1824.

Materiais selecionados: 10-XI-2003, P.B. Schwartsburd 45 (RB); 10-VI-2004, P.B. Schwartsburd \& F.B. Matos 188 (MBM), 189 (HUPG), 190 (SP), 192 (UPCB); 21-VIII-2004, P.B. Schwartsburd et al. 286 (UPCB); 16-V-2005, P.B. Schwartsburd \& M. Nogueira Júnior 790 (MBM).

Distribuição: Brasil (N, SE e S), Paraguai, Argentina e Uruguai.

Esta espécie foi comumente encontrada no PEVV, ocorrendo como epífita e rupícola, no interior da Floresta com Araucária e nas Formações Areníticas.

Campyloneurum nitidum assemelha-se de um modo geral (tamanho e forma da lâmina, e tamanho do pecíolo) a $C$. acrocarpon Fée, da qual difere pela textura coriácea da lâmina e pelo caule compacto e curto-reptante, enquanto que $C$. acrocarpon apresenta a lâmina membranácea e o caule delgado e longo-reptante.

\section{Cochlidium Kaulf.}

Cochlidium serrulatum (Sw.) L.E. Bishop, Amer. Fern J. 68: 80. 1978. Acrostichum serrulatum Sw., Prodr.: 128. 1788.

Material selecionado: 10-XI-2003, P.B. Schwartsburd 46 (HUPG, MBM, SP, UPCB).

Distribuição: África, Madagascar, Mauritius; México (S), Mesoamérica, Antilhas, Trinidad, Colômbia, Venezuela, Equador (incluindo Galápagos), Peru, Bolívia e Brasil (N, NE, CO, SE e S).

Esta espécie foi encontrada exclusivamente como rupícola nas Formações Areníticas, formando grandes e densas populações.

Cochlidium serrulatum é facilmente distinguível das demais espécies do gênero pela lâmina serrulada (Labiak \& Prado 2003). 
Ctenitis (C. Chr.) C. Chr.

Chave para as espécies de Ctenitis encontradas no PEVV

1. Escamas do caule com mais de $2,5 \mathrm{~cm}$ compr., amareladas, densas, formando "almofadas"; escamas do pecíolo e da raque laxas

2. Escamas da raque subclatradas, com as paredes celulares amareladas a alaranjadas; pinas proximais deflexas C. submarginalis

2. Escamas da raque clatradas, com as paredes celulares marrom-escuras a negras; pinas proximais geralmente patentes C. distans

1. Escamas do caule com menos de $1,5 \mathrm{~cm}$ compr., castanho-claras ou castanho-escuras, não formando "almofadas"; escamas do pecíolo e da raque rígidas

3. Escamas da raque clatradas, com as paredes celulares marrom-escuras a negras; face adaxial da lâmina com o tecido laminar glabro C. falciculata

3. Escamas da raque subclatradas, com as paredes celulares avermelhadas; face adaxial da lâmina com o tecido laminar com conspícuos tricomas unicelulares C. bigarellae

Ctenitis bigarellae Schwartsburd et al., Brittonia 59(1): 29. 2007.

Materiais selecionados: 22-XII-2004, P.B. Schwartsburd \& T. Takeuchi 565 (BHCB, NY); 6-III-2005, P.B. Schwartsburd et al. 680 (PACA, RB); 15-V-2005, P.B. Schwartsburd \& M. Nogueira Júnior 776 (SP), 778 (BHCB, HUPG, UPCB); 28-X-2005, P.B. Schwartsburd et al. 944 (MBM, UC, UPCB).

Distribuição: Endêmica ao Estado do Paraná.

Esta espécie foi encontrada como rupícola e terrícola (mais raramente) nas Formações Areníticas, em locais muito sombrios e úmidos, parecendo ocupar o mesmo nicho restrito de Alsophila capensis subsp. polypodioides e Blechnum divergens, no PEVV.

Ctenitis bigarellae pode ser reconhecida pelo seu hábito rupícola, caule com escamas com a margem ciliada, não formando tufos, lâmina finamente membranácea, segmentos com o ápice obtuso, tecido laminar pubescente (com tricomas unicelulares, filiformes) em ambas as faces, escamas da raque avermelhadas, rígidas, subclatradas, e indúsio ciliado. No Brasil, a espécie mais semelhante é Ctenitis abyssi (Sehnem) Salino \& O. Morais, a qual pode ser ditinguida pela ausência de tricomas no tecido laminar entre-nervuras, escamas da raque com até $4 \mathrm{~mm}$ compr., buliformes, margens dos segmentos denteadas, além do ápice das pinas longo-acuminado.

Ctenitis distans (Brack.) Ching, Bull. Fan. Mem. Inst. Biol. Bot. 8(5): 277. 1938. Lastrea distans Brack., U.S. Expl. Exped. Filic. 16: 192. 1854.

Materiais selecionados: 6-IV-2004, P.B. Schwartsburd
\& M. Nogueira Júnior 113 (MBM, UPCB), 114 (BHCB, HUPG, UPCB); 23-X-2004, P.B. Schwartsburd \& $R$. Nagata 369 (SP, UPCB); 18-XII-2004, P.B. Schwartsburd et al. 475 (BHCB, MBM).

Distribuição: Endêmica ao Brasil (NE, SE e S).

Esta espécie foi encontrada como terrícola no interior e borda da Floresta com Araucária.

Segundo Christensen (1913), esta espécie (citada como Dryopteris ctenitis (Link) O. Ktze.) apresenta muitas características intermediárias entre Ctenitis falciculata (Raddi) Ching e C. submarginalis (Langsd. \& Fisch.) Ching. O presente trabalho delimita como C. falciculata, plantas que apresentam as escamas do caule marrons e não formando "almofadas", restringindo assim as possíveis formas intermediárias. Para a delimitação entre C. submarginalis e C. distans, utilizou-se as principais características apontadas por Christensen (l.c.): C. distans - lâmina escura quando herborizada, pinas proximais patentes, escamas da raque marromescuras a negras; $C$. submarginalis - lâmina verde clara quando herborizada, pinas proximais deflexas, escamas da raque amareladas ou avermelhadas.

Ctenitis falciculata (Raddi) Ching, Sunyatsenia 5: 250. 1940. Aspidium falciculatum Raddi, Opusc. Sci. Bol. 3: 289. 1819.

Materiais selecionados: 11-X-2003, P.H. Labiak \& P.B. Schwartsburd 2987 (BHCB, UPCB); 21-VIII-2004, P.B. Schwartsburd et al. 310 (BHCB, HUPG, MBM, UPCB); 18-XII-2004, P.B. Schwartsburd et al. 494 (UPCB); 29-X-2005, P.B. Schwartsburd et al. 969 (HUPG, MBM, UPCB), 
971 (HUPG, MBM, UPCB).

Distribuição: Guiana e Brasil (NE, SE e S).

Esta espécie foi encontrada como terrícola no interior da Floresta com Araucária, principalmente nas margens de riachos e córregos.

Ctenitis submarginalis (Langsd. \& Fisch.) Ching, Sunyatsenia 5: 250.1940. Polypodium submarginale Langsd. \& Fisch., Pl. Voy. Russes Monde: 12. 1810.
Material selecionado: 14-XII-2004, P.B. Schwartsburd \& F.B. Matos 456 (HUPG, MBM, UPCB).

Distribuição: E.U.A. (S), México (E e S), Mesoamérica, Hispaniola, Colômbia, Venezuela, Equador, Peru, Bolívia, Brasil (NE, CO, SE e S), Paraguai, Argentina (N) e Uruguai.

Esta espécie foi encontrada como terrícola no interior da Floresta com Araucária.

\section{Cyathea Sm.}

Chave para as espécies de Cyathea encontradas no PEVV

1. Ápice da lâmina conforme, formando uma pina apical articulada à raque; pínulas inteiras ou raramente pinatífidas C. corcovadensis

1. Ápice da lâmina gradualmente reduzido a um segmento terminal pinatissecto, não conforme e não articulado à raque; pínulas pinatífidas ou pinatissectas

2. Nervuras secundárias predominantemente simples

C. atrovirens

2. Nervuras secundárias predominantemente furcadas

3. Caule com cicatrizes foliares evidentes, sem restos peciolares; indúsio globoso persistente C. delgadii

3. Caule com restos peciolares persistentes (cicatrizes não evidentes); indúsio ausente

4. Base do pecíolo com escamas com aproximadamente 3,5 (-4) cm compr.; raque com espinhos; costa e cóstula exclusivamente com escamas infladas e alvacentas C. phalerata

4. Base do pecíolo com escamas com no máximo $3 \mathrm{~cm}$ compr.; raque sem espinhos; costa e cóstula com tricomas e escamas não infladas

5. Base do pecíolo com verrugas, espinhos com até $2 \mathrm{~mm}$ compr. e escamas concolores, castanho-escuras Cyathea sp.

5. Base do pecíolo liso ou verrugoso, sem espinhos, com escamas bicolores, ferrugíneas com a margem alvacenta C. villosa

Cyathea atrovirens (Langsd. \& Fisch.) Domin, Pteridophyta: 262. 1929. Polypodium atrovirens Langsd. \& Fisch., Icon. fil.: 12. 1810.

Materiais selecionados: 15-XII-2003, P.B. Schwartsburd \& A.C. Hatschbach 48 (SP, UPCB); 7-I-2004, P.H. Labiak \& P.B. Schwartsburd 3093 (UPCB); 5-IV-2004, P.B. Schwartsburd \& M. Nogueira Júnior 74 (SP); 21-VIII-2004, P.B. Schwartsburd et al. 324 (HUPG, MBM).

Distribuição: Brasil (NE, SE e S), Paraguai e Argentina.

Esta espécie foi comumente encontrada nas regiões de Campos Gerais, tanto em áreas secas como úmidas; também foi encontrada no interior da Floresta com Araucária e em matas alteradas com Pinus spp. e Eucalyptus spp.
Esta espécie pode variar em muitos dos seus caracteres, dependendo do ambiente onde ocorre (e.g. tamanho do caule, das frondes e das pinas, e grau de pubescência). No entanto, pode ser caracterizada por apresentar as nervuras secundárias simples e os espinhos distribuídos desde a base do pecíolo até a raque, abundantes.

Cyathea corcovadensis (Raddi) Domin, Pteridophyta: 262. 1929. Polypodium corcovadense Raddi, Opusc. Sci. Bol. 3: 288. 1819.

Materiais selecionados: 13-XII-1969, G.G. Hatschbach 23226 (UPCB); 15-XII-2003, P.B. Schwartsburd \& A.C. Hatschbach 57 (HUPG, UPCB), 69 (HUPG); 6-IV-2004, P.B. Schwartsburd \& M. Nogueira Júnior 98 (HUPG); 16-V-2005, P.B. 
Schwartsburd \& M. Nogueira Júnior 801 (MBM).

Distribuição: Endêmica ao Brasil (NE, SE e S).

Esta espécie foi encontrada no interior da Floresta com Araucária, em matas alteradas com Pinus spp., com Eucalyptus spp. e nos Campos (áreas secas e úmidas). Foi encontrada, no PEVV, também em ambientes ruderais, como valetas e canalizações de córregos.

Apesar das pínulas apresentarem um alto grau de variação morfológica (inteiras a pinatilobadas, com 2,5 a mais de $10 \mathrm{~cm}$ compr.), Cyathea corcovadensis é facilmente identificada por apresentar o ápice da lâmina conforme, formando uma "pina apical" articulada à raque, as pinas com o ápice inteiro e conforme, e não gradualmente reduzido (como nas outras espécies do gênero presentes no PEVV); além do pecíolo com os espinhos restritos à base, não se estendendo pela raque.

Cyathea delgadii Sternb., Flor. Der Vorwelt 1: 47, t. B. 1820.

Materiais selecionados: 10-VI-2004, P.B. Schwartsburd \& F.B. Matos 223 (MBM, SP, UPCB); 14-XII-2004, P.B. Schwartsburd \& F.B. Matos 444 (HUPG, MBM, UPCB).

Distribuição: Costa Rica, Panamá, Colômbia, Venezuela, Guiana, Peru, Bolívia, Brasil (Ilha da Trindade, N, NE, CO, SE e S), Paraguai e Argentina (N).

Esta espécie foi encontrada preferencialmente como terrícola no interior da Floresta com Araucária, mas também foi encontrada como rupícola (humícola) nas Formações Areníticas.

Cyathea delgadii também pode apresentar escamas grandes (até $3,5 \mathrm{~cm}$ compr.) na base do pecíolo, além de apresentar grande porte, pínulas pinatissectas e as nervuras secundárias furcadas - podendo assim ser confundida com C. phalerata Mart. Porém, a presença de cicatrizes foliares evidentes no caule, e os soros com indúsio são características exclusivas de $C$. delgadii; enquanto que em $C$. phalerata as bases dos pecíolos são persistentes sobre o caule e os soros não possuem indúsio.

Cyathea phalerata Mart., Denkschr. Bayer. Bot. Ges. Regensburg 2: 146. 1822.

Materiais selecionados: 7-I-2004, P.H. Labiak \& P.B. Schwartsburd 3080 (MBM, SP, UPCB); 5-IV-2004, P.B. Schwartsburd \& M. Nogueira Júnior 97 (HUPG, UPCB); 10-VI-2004, P.B. Schwartsburd \&

\section{F.B. Matos 217 (COR).}

Distribuição: Endêmica ao Brasil (NE, CO, SE e S).

Esta espécie foi encontrada como terrícola no interior da Floresta com Araucária e em matas alteradas com Pinus spp.

Uma característica marcante de Cyathea phalerata é a presença de escamas infladas e alvacentas, abundantes na costa e cóstula.

Cyathea villosa Humb. \& Bonpl. ex Willd., Sp. pl. 5: 495. 1810.

Materiais selecionados: 23-X-2004, P.B. Schwartsburd \& R. Nagata 413 (HUPG, UPCB), 415 (MBM); 28X-2005, P.B. Schwartsburd et al. 938 (UPCB).

Distribuição: Panamá, Colômbia, Venezuela, Guianas, Bolívia, Brasil (NE, CO, SE e S), Paraguai, Chile e Argentina.

Esta espécie foi encontrada exclusivamente na base de arenitos isolados nos Campos Gerais, como terrícola ou rupícola (das fendas das rochas).

Cyathea villosa difere de Cyathea atrovirens por apresentar a base do pecíolo com escamas de margem alvacenta, raque inerme e nervuras secundárias furcadas e imersas. Já $C$. atrovirens apresenta a base do pecíolo com escamas concolores ou com bordo mais claro (porém nunca alvacento), raque com espinhos e nervuras secundárias predominantemente simples e emersas.

\section{Cyathea sp.}

Material selecionado: 21-VIII-2004, P.B. Schwartsburd et al. 323 (MBM, UPCB).

Esta espécie foi encontrada como rupícola (humícola) da base de arenitos isolados nos Campos Gerais.

Cyathea sp. é bastante semelhante a alguns espécimes de $C$. atrovirens, principalmente por apresentar o caule arborescente, com pouco mais de $1 \mathrm{~m}$ compr., com as bases peciolares persistentes, e pínulas pinatífidas. No entanto, apresenta como características marcantes a presença de escamas lineares (a levemente linear-lanceoladas) e castanhoescuras, além dos espinhos diminutos e restritos à base do pecíolo.

\section{Dennstaedtia Bernh.}

Dennstaedtia obtusifolia (Willd.) T. Moore, Ind. fil.: 306. 1861. Dicksonia obtusifolia Willd., Sp. pl. ed. 4, 5: 483. 1810. 
Materiais selecionados: 21-VIII-2004, P.B. Schwartsburd et al. 322 (HUPG, MBM, UPCB); 6-III-2005, P.B. Schwartsburd et al. 671 (UPCB).

Distribuição: Colômbia, Venezuela, Peru, Equador e Brasil (SE e S).

Esta espécie foi encontrada como rupícola (humícola) na margem de córregos e riachos, no interior da Floresta com Araucária.

Dennsatedtia obtusifolia difere de Dennstaedtia globulifera (Poir.) Hieron. pelo caule glabrescente, indiviso, gemas presentes na base do pecíolo que podem produzir novos caules, os quais, segundo Navarrete \& Øllgaard (2000) seriam “caules secundários", e ausência de alas perpendiculares conectando a raquíola à costa; enquanto que D. globulifera apresenta o caule densamente piloso, dicotomicamente ramificado, ausência de caules secundários, e raquíola e costa com alas perpendiculares e decorrentes entre si.

Difere de Dennstaedtia cicutaria (Sw.) T. Moore pela lâmina esparsamente pilosa e presença exclusiva de tricomas catenados; enquanto que D. cicutaria apresenta a lâmina densamente pilosa, com tricomas de dois tipos: catenados e aciculares (abundantes no tecido laminar).

Uma outra espécie muito semelhante a esta é Dennstaedtia dissecta (Sw.) T. Moore, que parece ocorrer apenas nas Antilhas, Mesoamérica e norte da América do Sul (Navarrete \& Øllgaard 2000).

Deparia Hook. \& Grev.

Deparia petersenii (Kunze) M. Kato, Bot. Mag. (Tokyo) 90: 37. 1977. Asplenium petersenii Kunze, Analecta Pteridogr. 24. 1837.

Materiais selecionados: 7-I-2004, P.H. Labiak \& P.B. Schwartsburd 3089 (COR, RB, UPCB); 8-I-2005, P.B. Schwartsburd et al. 604 (HUPG); 22-IV-2005, P.B. Schwartsburd et al. 727 (MBM, SP); 29-X-2005, P.B. Schwartsburd et al. 980 (RB).

Distribuição: Ásia, Oceania e Ilhas do Pacífico; E.U.A. (SE, Havaí) e Brasil (SE e S).

Esta espécie foi encontrada como terrícola e rupícola, principalmente no interior de matas alteradas com Pinus spp., com Eucalyptus spp., florestas em regeneração e ambientes ruderais, geralmente em locais úmidos.

Segundo Kato (1993) este gênero compreende ca. 50 spp., com apenas duas ocorrendo na América: uma nativa dos E.U.A. e Deparia petersenii, originária da Ásia e naturalizada nesse continente. Tanto no PEVV, como em outras localidades do Estado do Paraná, esta espécie é abundantemente encontrada em ambientes alterados e ruderais.

\section{Dicksonia L’Hér.}

Dicksonia sellowiana Hook., Sp. fil. 1: 67. 1844.

Material selecionado: 7-I-2004, P.H. Labiak \& P.B. Schwartsburd 3050 (UPCB).

Distribuição: México (S), Mesoamérica, Colômbia, Venezuela, Equador, Peru, Bolívia, Brasil (SE e S), Paraguai e Uruguai.

Esta espécie é popularmente conhecida como xaxim, xaxim-bugio ou xaxim verdadeiro, e muito utilizada na ornamentação doméstica: secções do caule são utilizadas como substrato para plantas ornamentais, principalmente orquídeas. Porém, sua utilização no Brasil esteve sempre atrelada ao extrativismo e nunca a cultivos, fato que levou o IBAMA a considerar Dicksonia sellowiana uma espécie em perigo de extinção - Portaria 37-N (3-IV-1992) do IBAMA (1992) - restringindo legalmente a comercialização dos substratos (xaxins).

No PEVV foram encontradas algumas poucas populações desta espécie, porém grandes populações com indivíduos chegando a apresentar caules com até $40 \mathrm{~cm}$ diâm., principalmente em regiões de baixadas da Floresta com Araucária, e também em associação com as Formações Areníticas.

\section{Dicranopteris Bernh.}

Chave para as espécies de Dicranopteris encontradas no PEVV

1. Lâmina sem pinas reflexas na base das dicotomias; face abaxial da costa com abundantes tricomas avermelhados.

D. nervosa

1. Lâmina com um par de pinas reflexas na base das dicotomias; face abaxial da costa glabra

D. flexuosa

Dicranopteris flexuosa (Schrad.) Underw., Bull. Torrey Bot. Club 34: 254. 1907. Mertensia flexuosa Schrad., Gött. Gel. Anz. 1824: 863. 1824.

Materiais selecionados: 7-III-2005, P.B. Schwartsburd 686 (UPCB); 15-V-2005, P.B. Schwartsburd \& Nogueira Júnior 781 (HUPG, UPCB); 16-V-2005, P.B. Schwartsburd \& M. Nogueira Júnior 796 
(HUPG), 798 (HUPG, MBM, SP, UPCB).

Distribuição: E.U.A. (SE), México (S), Mesoamérica, Antilhas, Trinidad, Colômbia, Venezuela, Guianas, Equador, Peru, Bolívia, Brasil (NE, CO, SE e S) e Paraguai.

Esta espécie foi encontrada em uma gama enorme de ambientes: tanto nos Campos Gerais, como na borda da Floresta com Araucária e nas Formações Areníticas, como terrícola e rupícola. Nos paredões das Furnas, paredes expostas das Formações Areníticas e em depressões ao longo de córregos ou rios dos Campos Gerais, esta espécie parece ser o elemento rupícola dominante, formando grandes e densas populações.

O material examinado apresenta uma ampla variação morfológica, os maiores espécimes são terrestres e os menores rupícolas. A variação da margem dos segmentos parece estar ligada a heliofilia: revoluta em plantas de ambientes heliófilos e plana em plantas de ambientes mais ombrófilos e úmidos. A segmentação da lâmina também parece estar ligada ao hábito e hábitat: poucas vezes divididas (frondes eretas) em plantas de locais sem apoios, por exemplo, rupícola de paredões, e várias vezes divididas (frondes arqueadas) em plantas de locais com apoio adjacente, por exemplo, terrestre do interior da mata, apoiandose na vegetação do entorno.

Dicranopteris nervosa (Kaulf.) Maxon, Contr. U.S. Nat. Herb. 24: 49. 1922. Mertensia nervosa Kaulf., Enum. fil.: 37. 1824.

Material selecionado: 29-X-2005, P.B. Schwartsburd et al. 987 (COR, HUPG, MBM, RB, SP, UPCB).

Distribuição: Peru, Bolívia, Brasil (SE e S), Paraguai, Argentina e Uruguai.

Esta espécie foi encontrada como terrícola em barrancos, em ambientes muito alterados. Apenas uma população em associação com Dicranopteris flexuosa foi encontrada.

Didymochlaena Desv.

Didymochlaena truncatula (Sw.) J. Sm., J. Bot. (Hooker) 4: 196. 1841. Aspidium truncatulum Sw., J. Bot. (Schrader) 1800(2): 36. 1801.
Material selecionado: 21-X-2004, P.B. Schwartsburd et al. 318 (HUPG, MBM, UPCB).

Distribuição: Ásia, Oceania, Ilhas do Pacífico, África; México (S), Mesoamérica, Grandes Antilhas, Trinidad, Colômbia, Venezuela, Guianas, Equador, Peru, Bolívia, Brasil (N, NE, SE e S), Paraguai, Argentina (N) e Uruguai.

Esta espécie foi encontrada exclusivamente como terrícola às margens de riachos, no interior da Floresta com Araucária.

Segundo Tryon \& Stolze (1991) e Mickel \& Smith (2004) este gênero compreende apenas esta espécie, a qual é cosmopolita. Apesar desta espécie ser abundantemente encontrada em outras regiões do Estado (e.g. Parque Estadual Vila Rica do Espírito Santo, Reserva Ecológica da Klabin observações pessoais), ela foi raramente encontrada no PEVV, sendo exclusiva do ambiente acima citado.

Diplazium Sw.

Diplazium leptocarpon Fée, Crypt. Vasc. Brés. 1: 80. 1869.

Materiais selecionados: 21-VIII-2004, P.B. Schwartsburd et al. 302 (RB, UPCB); 8-I-2005, P.B. Schwartsburd et al. 599 (HUPG, MBM, RB); 29-X-2005, P.B. Schwartsburd et al. 963 (RB, UPCB).

Distribuição: endêmica às regiões Sul e Sudeste do Brasil.

Esta espécie foi encontrada como rupícola (humícola) às margens de riachos, no interior da Floresta com Araucária.

Diplazium leptocarpon é similar a $D$. rostratum Fée, que apresenta escamas do caule e dos eixos vasculares com dentes bífidos, e pínulas inteiras a levemente serreadas. Já D. leptocarpon apresenta as escamas do caule e dos eixos vasculares com dentes simples, e pínulas pinatífidas a pinatissectas. Segundo Cislinski (1996), as escamas de D. rostratum são dicromáticas e as de D. leptocarpon, monocromáticas. 
Doryopteris J. Sm.

Chave para as espécies de Doryopteris encontradas no PEVV

1. Nervuras anastomosadas

2. Lâmina fértil com gemas prolíferas na base; soros não interrompidos D. nobilis

2. Lâmina fértil sem gemas; soros interrompidos nos sínus D. pentagona

1. Nervuras livres (simples e/ou furcadas)

3. Frondes monomorfas a levemente dimorfas; pecíolo canaliculado adaxialmente; segmentos estéreis com o ápice acuminado. D. concolor

3. Frondes nitidamente dimorfas; pecíolo não canaliculado; segmentos estéreis com o ápice arredondado

4. Lâmina fértil com os soros interrompidos nos sinus; tecido laminar entre os segmentos com estreitamentos, oblíquo à raque. Lâmina estéril com os segmentos com a margem lobada ou crenada, verde, membranácea D. crenulans

4. Lâmina fértil com os soros contínuos; tecido laminar entre os segmentos sem estreitamentos, paralelo à raque. Lâmina estéril com os segmentos com a margem inteira, castanho-escura, esclerificada D. lomariacea

Doryopteris concolor (Langsd. \& Fisch.) Kuhn in Decken, Bot. Ost-Afrika 3(3): 19. 1879. Pteris concolor Langsd. \& Fisch., Icon. fil.: 19. 1810.

Materiais selecionados: 23-X-2004, P.B. Schwartsburd \& R. Nagata 371 (HUPG, UPCB), 372 (MBM).

Distribuição: Ásia, Oceania, Ilhas do Pacífico, África; México (S), Mesoamérica, Antilhas, Colômbia, Venezuela, Equador, Peru, Bolívia, Brasil (N, NE, CO, SE e S), Paraguai, Argentina e Uruguai.

Esta espécie foi encontrada como terrícola de locais encharcados, em áreas de transição entre os Campos e a Floresta.

Doryopteris crenulans (Fée) H. Christ in Schwacke, Pl. Nov. Mineir. 2: 26. 1900. Pellaea crenulans Fée, Crypt. Vasc. Brés. 2: 27. 1873.

Materiais selecionados: 10-VI-2004, P.B. Schwartsburd \& F.B. Matos 186 (MBM), 187 (UPCB); 22-X-2004, P.B. Schwartsburd \& $R$. Nagata 356 (HUPG, UPCB).

Distribuição: Peru, Bolívia e Brasil (SE e S).

Esta espécie foi encontrada como terrícola nas áreas de Campo, secas e úmidas.

Doryopteris lomariacea Klotzsch, Linnaea 20: 343. 1847.

Materiais selecionados: 11-X-2003, P.H. Labiak \& P.B. Schwartsburd 2983 (HUPG, SP); 7-I-2004, P.H. Labiak \& P.B. Schwartsburd 3058 (MBM, UPCB).
Distribuição: Venezuela, Guiana, Peru, Brasil (CO, SE e S), e Paraguai.

Esta espécie foi encontrada como terrícola nos Campos, principalmente em locais com o solo encharcado (Campos úmidos).

Doryopteris nobilis (T. Moore) C. Chr., Ind. fil.: 244. 1905. Litobrochia nobilis T. Moore, Gard. Chron. Oct. 1862: 932. 1862.

Material selecionado: 23-X-2004, P.B. Schwartsburd \& R. Nagata 368 (HUPG, MBM, UPCB).

Distribuição: Colômbia, Bolívia, Brasil (NE, CO, SE e S), Paraguai e Argentina (incluindo as Malvinas).

Esta espécie foi encontrada como terrícola em áreas de transição entre os Campos e a Floresta, em locais encharcados. Nestes ambientes é também comum a ocorrência de Doryopteris concolor.

Doryopteris pentagona Pic.Serm., Webbia 60(1): 231. 2005.

Materiais selecionados: 25-II-1967, G.G. Hatschbach \& O. Guimarães 16074 (UPCB); 7-I-2004, P.H. Labiak \& P.B. Schwartsburd 3061 (HUPG, MBM, SP); 5-IV-2004, P.B. Schwartsburd \& M. Nogueira Júnior 93 (UPCB).

Distribuição: Guiana, Bolívia, Brasil (NE, CO, SE e S), Paraguai e Argentina.

Esta espécie foi encontrada como terrícola no interior da Floresta com Araucária, preferencialmente em terrenos alagadiços. 
Elaphoglossum Schott ex J. Sm., nom. cons.

Chave para as espécies de Elaphoglossum encontradas no PEVV

1. Lâmina estéril 8 ou mais vezes mais comprida que larga

2. Caule longo-reptante, esparsamente escamoso a glabro; lâmina estéril com até $2(-2,5) \mathrm{cm}$ larg.

E. burchellii

2. Caule curto-reptante, densamente escamoso; lâmina estéril com mais de $3 \mathrm{~cm}$ larg.

3. Caule horizontal; face abaxial da lâmina estéril com diminutas escamas estreladas esparsas Elaphoglossum sp.

3. Caule ascendente; face abaxial da lâmina estéril completamente revestida por escamas lanceoladas e ciliadas E. langsdorffii

1. Lâmina estéril até 5 vezes mais comprida que larga

4. Lâmina estéril com mais de $7 \mathrm{~cm}$ larg.; nervuras livres e anastomosadas E. macrophyllum

4. Lâmina estéril com até $5 \mathrm{~cm}$ larg.; nervuras livres, nunca anastomosadas

5. Lâmina estéril com o ápice arredondado ou obtuso E. lingua

5. Lâmina estéril com o ápice agudo E. vagans

Elaphoglossum burchellii (Baker) C.Chr., Ind. fil.: 304. 1905. Acrostichum burchellii Baker in Hook. \& Baker, Syn. fil.: 4011868.

Materiais selecionados: 7-I-2004, P.H. Labiak \& P.B. Schwartsburd 3098 (MBM, HUPG, RB, SP); 19-XII-2004, P.B. Schwartsburd et al. 510 (UPCB); 13-I-2005, P.B. Schwartsburd 627 (PACA).

Distribuição: Grandes Antilhas, Costa Rica, Panamá, Colômbia, Venezuela, Equador, Peru, Bolívia, Brasil (SE e S) e Paraguai.

Esta espécie foi encontrada principalmente como rupícola nas Formações Areníticas, formando densas populações. Mas também foram encontradas populações terrícolas, no interior da Floresta com Araucária e em matas ciliares.

Elaphoglossum langsdorffii (Hook. \& Grev.) T. Moore, Ind. fil.: 11. 1857. Acrostichum langsdorffii, Hook. \& Grev., Icon. fil.: t. 164. 1829.

Materiais selecionados: 14-I-2005, P.B. Schwartsburd et al. 630 (MBM); 28-X-2005, P.B. Schwartsburd et al. 945 (UPCB).

Distribuição: Aparentemente endêmica às regiões Sul e Sudeste do Brasil.

Esta espécie foi raramente encontrada no PEVV, ocorrendo como rupícola nas Formações Areníticas.

Segundo a bibliografia consultada (Christ 1899, Alston 1958, Brade 1961, Sehnem 1979a, Mickel 1995, Novelino 1998, Rojas-Alvarado 2002), existe uma certa discrepância quanto à aceitação da distribuição desta espécie. Alguns autores afirmam que ela é restrita ao Sul e Sudeste do Brasil, e outros, que é distribuída em várias regiões da América do Sul. Porém, tanto considerando uma distribuição ampla quanto restrita, os dados bibliográficos e pesquisa nos herbários HUEPG, MBM, RB, SP e UPCB, indicam que o presente registro, juntamente com o de Schwacke 2550 (RB) para o Município de São Bento (Paraná), sejam os supostos limites austrais de distribuição de Elaphoglossum langsdorffii (s.l. vel s.s.).

Das espécies próximas, como Elaphoglossum edwallii Rosenst. e E. cuspidatum (Willd.) T. Moore, $E$. langsdorffii diferencia-se por não apresentar escamas escuras no pecíolo e raque, e pelo ápice da lâmina não caudado. Difere de E. plumosum (Fée) T. Moore pelo pecíolo bem definido, não alado e maior que $1 / 2$ do comprimento da lâmina; enquanto que em E. plumosum o pecíolo é praticamente indefinido (lâmina profundamente decorrente na base) ou menor que $1 / 2$ do comprimento da lâmina.

Elaphoglossum lingua (C. Presl) Brack., U. S. Expl. Exped., Filic. 16: 74. 1854. Olfersia lingua C. Presl, Tent. Pterid.: 235. 1836.

Materiais selecionados: 31-III-1963, G.G. Hatschbach 9984 (MBM); 22-XII-2004, P.B. Schwartsburd \& T. Takeuchi 559 (HUPG, UPCB).

Distribuição: Antilhas, Costa Rica, Panamá, Colômbia, Venezuela, Guiana Francesa, Equador, Peru, Bolívia, Brasil (SE e S), Paraguai e Chile. 
Esta espécie foi encontrada como rupícola nas Formações Areníticas.

Elaphoglossum macrophyllum (Mett.) H. Christ, Bull. Herb. Boiss. sér. 2, 5: 10. 1905. Acrostichum macrophyllum Mett. ex Kuhn, Linnaea 36: 61. 1869.

Materiais selecionados: 6-III-2005, P.B. Schwartsburd et al. 668 (MBM, UPCB), 669 (HUPG, RB, SP).

Distribuição: Venezuela, Equador, Bolívia e Brasil (SE e S).

Esta espécie foi encontrada como terrícola no interior da Floresta com Araucária, formando densas populações. Também encontrada como rupícola nas Formações Areníticas.

Brade (1961) considera a espécie brasileira como Elaphoglossum hymenodiastrum (Fée) Brade, distinta de E. macrophyllum. Porém segundo Alston (1958), Sehnem (1979a) e Labiak \& Prado (1998), E. hymenodiastrum trata-se de um sinônimo de E. macrophyllum, sendo este o nome correto a ser aplicado a este táxon.

Elaphoglossum vagans (Mett.) Hieron., Bot. Jahrb. Syst. 34: 543. 1904. Acrostichum vagans Mett. in Kuhn, Linnaea 36: 58. 1869.

Materiais selecionados: 11-X-2003, P.H. Labiak \& P.B. Schwartsburd 2964 (HUPG, RB); 21-VIII-2004, P.B. Schwartsburd et al. 264 (SP); 14-XII-2004, P.B. Schwartsburd \& F.B. Matos 448 (MBM, UPCB); 18-XII-2004, P.B. Schwartsburd et al. 493 (UPCB).

Distribuição: Endêmica às regiões Sul e Sudeste do Brasil.

Esta espécie foi encontrada como rupícola nas Formações Areníticas e no interior da Floresta com Araucária.

\section{Elaphoglossum sp.}

Materiais selecionados: 7-I-2004, P.H. Labiak \& P.B. Schwartsburd 3071 (HUPG, RB, SP, UPCB); 12-I-2005, P.B. Schwartsburd \& A.C. Hatschbach 623 (MBM); 6-III-2005, P.B. Schwartsburd et al. 677 (MBM).

Esta espécie foi encontrada como rupícola nas Formações Areníticas, formando densas populações. Também encontrada, raramente, no interior da Floresta com Araucária.

Elaphoglossum sp. é bastante semelhante a $E$. wettsteinii $\mathrm{H}$. Christ e E. sellowianum (Klotzsch ex
Kuhn) T. Moore, principalmente por apresentar a lâmina elíptica a linear-lanceolada, com a base cuneada e curtamente decorrente ao pecíolo. No entanto, Elaphoglossum sp. é distinta pelo caule crasso e curto-reptante, enquanto que estas duas espécies apresentam o caule delgado e geralmente longoreptante.

A presente espécie enquadra-se como Elaphoglossum pachydermum (Fee) T. Moore sensu Sehnem (1979a), porém, como a aplicação deste nome ainda é incerta, resolveu-se identificá-la apenas em seu nível genérico.

\section{Eriosorus Fée}

Eriosorus aff. myriophyllus (Sw.) Copel., Gen. fil.: 58. 1947.

Materiais selecionados: 10-VI-2004, P.B. Schwartsburd \& F.B. Matos 240 (HUPG, MBM, SP, UPCB); 14-XII-2004, P.B. Schwartsburd \& F.B. Matos 439 (MBM, UPCB); 18-XII-2004, P.B. Schwartsburd et al. 487 (SP).

Distribuição: Brasil (SE e S) e Uruguai.

Esta espécie foi encontrada como rupícola, em pequenas depressões e fendas dos paredões das Formações Areníticas.

O presente material embora concorde com várias das características morfológicas citadas para a espécie por Prado (1995, 1997, 2004a) e Tryon (1970), apresenta algumas diferenças consideráveis: enquanto em tais descrições, Eriosorus myriophyllus apresenta o hábito preferencialmente terrestre, lâmina cartácea e tricomas glandulares; a presente espécie apresenta o hábito exclusivamente rupícola, lâmina finamente membranácea e tricomas pluricelulares sem glândula apical.

Tryon (1970) comentou sobre estas diferenças, encontradas em alguns materiais do Rio Grande do Sul e do Paraná, inclusive citando materiais oriundos de Vila Velha (Dusén 2900 e 4028). Esta autora considerou estes materiais como possíveis "citótipos" (traduzido), mas que provavelmente se tratem de formas "depauperadas" (traduzido) de locais rochosos.

Sehnem (1972) nomeou o material Hatschbach 10230, de Vila Velha, como Gymnogramma felipponei Hert., esta como uma espécie exclusiva de fendas de arenitos, diferindo de G. myriophylla Sw. (=Eriosorus myriophyllus), principalmente pelo tipo de indumento da lâmina e pelo caule cespitoso, além do hábito. 
Desta forma, seria necessária a análise do material-tipo de Gymnogramma felipponei para a clara delimitação destes dois táxons.

Histiopteris J. Agardh

Histiopteris incisa (Thunb.) J. Sm., Hist. Fil.: 295. 1875. Pteris incisa Thunb., Prodr. Pl. Cap.: 171. 1800.

Materiais selecionados: 10-VI-2004, P.B. Schwartsburd \& F.B. Matos 243 (UPCB, WIND), 244 (MBM), 245 (HUPG), 246 (SP); 15-V-2005, P.B. Schwartsburd \& M. Nogueira Júnior 780 (MBM, $\mathrm{RB}, \mathrm{UPCB})$.

Distribuição: Ásia (SE), Oceania, África; México (S), Mesoamérica, Antilhas, Colômbia, Venezuela, Equador, Peru, Bolívia, Brasil (SE e S), Chile (Ilhas Juan Fernández) e Ilhas Antárticas.

Esta espécie foi encontrada sobre rochas com acúmulo de húmus, nas Formações Areníticas.

De acordo com as descrições de Tryon \& Stolze (1989a), Histiopteris incisa difere de Blotiella lindeniana (Hook.) R.M. Tryon pelo caule longoreptante, lâmina glabra ou esparsamente pilosa e glauca abaxialmente, enquanto que $B$. lindeniana apresenta o caule ereto ou decumbente, lâmina pubescente e não glauca.

Segundo Prado (2004b) o gênero Histiopteris apresenta cinco espécies com ampla distribuição mundial, e de acordo com Moran (1995a), esta é uma das espécies de Pteridófitas mais amplamente distribuídas no Globo terrestre.

\section{Huperzia Bernh.}

Chave para as espécies de Huperzia encontradas no PEVV

1. Caule e ramos eretos ou levemente arqueados, com mais de $8 \mathrm{~mm}$ diâm. (incluindo os microfilos); microfilos deltóide-acuminados H. reflexa

1. Caule e ramos pendentes, com até 5 mm diâm. (incluindo os microfilos); microfilos de outro tipo

2. Microfilos elíptico-ovalados, menos de 2 vezes mais compridos que largos H. fontinaloides

2. Microfilos linear-acuminados, mais de 5 vezes mais compridos que largos H. acerosa
Huperzia acerosa (Sw.) Holub, Folia Geobot. Phytotax. 20: 70. 1985. Lycopodium acerosum Sw., Fl. Ind. Occid. 3: 1575. 1806.

Distribuição: Antilhas, Mesoamérica, Colômbia, Venezuela e Brasil (NE, SE e S).

Esta espécie não foi recoletada pelo presente trabalho, tendo seu registro para o Paraná citado por Nessel (1955): Fortaleza, Paraná, 22-XII-1903, Dusén 2897 (R), como Urostachys verticillatus (L.f.) Hert. Conforme o itinerário seguido por Dusén, a localidade de "Fortaleza" se refere à antiga Fazenda Fortaleza, atualmente situada dentro dos limites do PEVV. No entanto, o material citado por Nessel não foi localizado para a confirmação da ocorrência desta espécie.

De acordo com Øllgaard \& Windisch (1987), Urostachys verticillatus não ocorre no Brasil, e tal nome aplicado por Nessel (1955) corresponderia a Huperzia acerosa.

Huperzia fontinaloides (Spring) Trevis., Atti Soc. Ital. Sci. Nat. 17: 248. 1874. Lycopodium fontinaloides Spring in Mart., Fl. Bras. 1(2): 112. 1840.

Materiais selecionados: 5-III-2005, P.B. Schwartsburd et al. 656 (HUPG, MBM, RB, SP, UPCB); 28-X-2005, P.B. Schwartsburd et al. 955 (UPCB).

Distribuição: Endêmica às regiões Sul e Sudeste do Brasil.

Esta espécie foi encontrada como rupícola pendente nas Formações Areníticas.

Segundo Øllgaard \& Windisch (1987), Huperzia fontinaloides diferencia-se de $H$. quadrifariata (Bory) Trevis. pela coloração avermelhada da base do ramo e de alguns microfilos, e pela ausência de microfilos quadrangulares. Ainda de acordo com tais autores, $H$. fontinaloides difere de $H$. hexasticha B. Øllg. \& P.G. Windisch pelos microfilos dos segmentos basais com até $6 \mathrm{~mm}$ compr., enquanto que $H$. hexasticha apresenta microfilos basais com até $15 \mathrm{~mm}$ compr., além da coloração avermelhada ausente em $H$. hexasticha.

Huperzia reflexa (Lam.) Trevis., Atti Soc. Ital. Sci. Nat. 17: 248. 1874. Lycopodium reflexum Lam., Encycl. 3: 653. 1789.

Material selecionado: 20-XII-2004, P.B. Schwartsburd et al. 528 (MBM, UPCB).

Distribuição: México, Mesoamérica, Antilhas, Trinidad, Colômbia, Venezuela, Equador, Peru, Bolívia, Brasil (N, CO, SE e S) e Paraguai. 
Esta espécie foi encontrada como rupícola em cachoeiras dos Campos Gerais e também em áreas alagadiças, como terrícola.

Nessel (1955) menciona, em seu trabalho, uma coleta para o PEVV (Dusén 4060), a qual é determinada pelo autor como Urostachys rostrifolius (Silveira) Hert. ex Nessel. O presente material realmente assemelha-se com a ilustração apresentada por este autor. Porém, segundo Øllgaard \& Windisch (1987), Huperzia rostrifolia (Silveira) Holub seria uma espécie pouco distinta de $H$. christii (Silveira) Holub, sendo conhecida apenas da coleção-tipo, proveniente da Serra do Papagaio, Minas Gerais. Desta forma, a citação de $U$. rostrifolius, apresentada por Nessel (1955), parece ser um registro errôneo desta espécie para o Estado.

\section{Hymenophyllum Sm.}

Chave para as espécies de Hymenophyllum encontradas no PEVV

1. Frondes glabras H. polyanthos

1. Frondes com tricomas

2. Raque glabra ou com tricomas esparsos, nervuras glabras Hymenophyllum sp.

2. Raque e nervuras com tricomas

3. Raque não alada ou alada apenas na porção distal

4. Tecido laminar glabro H. pulchellum

4. Tecido laminar totalmente recoberto por tricomas H. rufum

3. Raque totalmente alada ou não alada apenas logo acima do par de pinas proximal

5. Tecido laminar com tricomas H. fragile

5. Tecido laminar glabro H. hirsutum

Hymenophyllum fragile (Hedw.) C.V. Morton, Contr. U.S. Nat. Herb. 29: 172. 1947. Trichomanes fragile Hedw., Fil. Gen. Sp. t. 18. 1802.

Materiais selecionados: 15-IV-1992, J. Cislinski \& A.C. Cervi 133 (UPCB); 26-VI-1999, M. Borgo 403 (UPCB); 11-X-2003, P.H. Labiak \& P.B. Schwartsburd 2982 (HUPG); 21-VIII-2004, P.B. Schwartsburd et al. 304 (MBM); 19-XII-2004, P.B. Schwartsburd et al. 512 (SP); 15-V-2005, P.B. Schwartsburd \& M. Nogueira Júnior 773 (MBM, UPCB), 777 (UPCB).

Distribuição: México, Mesoamérica, Grandes Antilhas, Colômbia, Venezuela, Equador, Peru, Bolívia e Brasil (SE e S).

Esta espécie foi encontrada como rupícola nas Formações Areníticas e no interior da Floresta com Araucária.

Hymenophyllum hirsutum (L.) Sw., J. Bot. (Schrader) 1800(2): 99. 1801. Trichomanes hirsutum L., Sp. pl.: 1098. 1753.

Materiais selecionados: 16-V-2005, P.B. Schwartsburd \& M. Nogueira Júnior 805 (MBM, UPCB);
19-X-2005, P.B. Schwartsburd et al. 908 (UPCB); $28-$ X-2005, P.B. Schwartsburd et al. 949 (MBM), 952 (HUPG, SP).

Distribuição: México, Mesoamérica, Antilhas, Colômbia, Venezuela, Guianas, Equador, Peru, Bolívia e Brasil (N, NE, SE e S).

Esta espécie foi encontrada como rupícola nas Formações Areníticas e nas rochas dos córregos dos Campos Gerais (ambientes parcialmente sombreados).

Lellinger (1991) afirma que o material do Sul e Sudeste do Brasil (RJ, SP, PR) tradicionalmente classificado com Hymenophyllum hirsutum corresponderia a Hymenophyllum vestitum (C. Presl) Bosch, e supostamente tal espécie seria endêmica desta região. Hymenophyllum hirsutum estaria então distribuído no resto do Neotrópico em geral, incluindo os Estados brasileiros AC, AM, PA e MG. As diferenças apresentadas por Lellinger (1991) não se mostraram muito consistentes para o material estudado, principalmente quanto ao tipo dos tricomas da margem da lâmina e largura dos segmentos. Assim, resolveu-se seguir o conceito também aplicado por Labiak \& Prado (1998), nomeando a presente espécie como H. hirsutum. 
Hymenophyllum polyanthos ( $\mathrm{Sw}$.) Sw., J. Bot. (Schrader) 1800(2): 102. 1801. Trichomanes polyanthos Sw., Prodr.: 137. 1788.

Material selecionado: 7-I-2004, P.H. Labiak \& P.B. Schwartsburd 3068 (HUPG, MBM, SP, UPCB).

Distribuição: Ásia (E), África, Antártida (N); México (C), Antilhas, Mesoamérica, Colômbia, Venezuela, Guianas, Equador, Peru, Bolívia e Brasil (N, NE, CO, SE e S).

Esta espécie foi encontrada como rupícola nas Formações Areníticas.

Pelas dimensões das frondes, o material analisado assemelha-se Hymenophyllum apiculatum Kuhn, uma espécie da Venezuela, Colômbia, Bolívia e Peru. Porém, difere quanto às características do indúsio: profundamente imerso em $\mathrm{H}$. apiculatum e levemente imerso em H. polyanthos (Tryon \& Stolze 1989b).

Hymenophyllum pulchellum Schltdl. \& Cham., Linnaea 5: 618. 1830.

Materiais selecionados: 21-VIII-2004, P.B. Schwartsburd et al. 267 (HUPG, MBM, SP); 21-IV-2005, P.B. Schwartsburd et al. 715 (UPCB); 28-X-2005, P.B. Schwartsburd et al. 946 (UPCB), 950 (MBM).

Distribuição: México (S), Mesoamérica e Brasil (SE e S).

Esta espécie foi encontrada como rupícola pendente, nas Formações Areníticas.

Uma característica marcante desta espécie é a presença de tufos de tricomas, freqüentemente presentes no caule e/ou no ápice das frondes.

Hymeophyllum pulchellum é muito similar a H. rufum Fée, principalmente, pelo hábito rupícola, formando densas populações, as frondes pendentes, com 20 a $30 \mathrm{~cm}$ compr. e de aparência bem tomentosa. Porém, difere de $H$. rufum pelos tricomas restritos às regiões vasculares e margem da lâmina, enquanto que H. rufum apresenta tricomas por todas as regiões da lâmina.

Hymenophyllum rufum Fée, Crypt. Vasc. Brés. 1: 198. 1869.

Materiais selecionados: 7-I-2004, P.H. Labiak \& P.B. Schwartsburd 3065 (HUPG, MBM, SP, UPCB); 14-XII-2004, P.B. Schwartsburd \& F.B. Matos 462 (MBM, UPCB).

Distribuição: Endêmica às regiões Sul e Sudeste do Brasil.
Esta espécie foi encontrada como rupícola pendente nas Formações Areníticas, formando grandes e densas populações.

Hymenophyllum rufum diferencia-se das demais espécies do gênero, encontradas no PEVV, por apresentar o tecido laminar não visível, totalmente recoberto pelos abundantes tricomas da lâmina.

\section{Hymenophyllum sp.}

Materiais selecionados: 16-V-2005, P.B. Schwartsburd \& M. Nogueira Júnior 786 (UPCB); 19-X-2005, P.B. Schwartsburd et al. 923 (MBM, UPCB).

Esta espécie foi encontrada como rupícola nas Formações Areníticas e nas rochas dos córregos dos Campos Gerais (ambientes parcialmente sombreados).

Das espécies mais semelhantes deve-se considerar Hymenophyllum elegans Spreng., que apresenta a lâmina lanceolada a linear, tricomas nas nervuras, raque e margem da lâmina, os tricomas da margem geralmente furcados e sésseis ou duas vezes furcados, raramente simples, estrelados ou biestrelados (Morton 1947). Em oposição, o material examinado apresenta a lâmina deltóide a deltóideovalada, tricomas ausentes nas nervuras, os tricomas da margem (maioria) trifurcados ou bifurcados e sesséis, outros poucos bi-estrelados.

Difere de Hymenophyllum elegans f. minor C.V. Morton pelas pinas pinatissectas, e não lineares ou bífidas apenas no ápice, como nesta espécie.

Hypolepis Bernh.

\section{Hypolepis sp.}

Material selecionado: 10-VI-2004, P.B. Schwartsburd \& F.B. Matos 231 (HUPG, MBM, UPCB).

Esta espécie foi raramente encontrada no PEVV, ocorrendo exclusivamente como rupícola no interior da Furna I, próxima a lâmina d'água.

Hypolepis sp. distingue-se das espécies H. repens (L.) C. Presl., H. nigrescens Hook. e H. hostilis (Kunze) C. Presl., citadas para o Brasil por Moran (1995b), Mickel \& Smith (2004), Tryon \& Stolze (1989a) e Prado (2004b), pelos eixos não espinescentes, frondes menores, com até 1,3 m compr. e pseudo-indúsio com mais de 0,5 mm larg.

De acordo com as descrições apresentadas por Tryon \& Stolze (1989a), Hypolepis sp. difere de H. bogotensis H. Karst., uma espécie extrabrasileira, pela lâmina pouco pubescente e base da 
raque não subdicótoma; e difere de $H$. obtusata (C. Presl) Kuhn, uma espécie também não registrada para o Brasil, pela raque tortuosa e lâmina deltóide.

\section{Lastreopsis Ching}

Lastreopsis amplissima (C. Presl) Tindale, Vict. Nat. 73: 185. 1957. Polystichum amplissimum C. Presl, Epim. Bot.: 58. 1851.

Materiais selecionados: 10-XI-2003, P.B. Schwartsburd 2 (MBM, SP); 21-VIII-2004, P.B. Schwartsburd et al. 309 (HUPG, RB); 28-X-2005, P.B. Schwartsburd et al. 942 (MBM, UPCB); 29-X-2005, P.B.
Schwartsburd et al. 976 (HUPG, RB, UPCB).

Distribuição: Venezuela, Bolívia, Brasil (SE e S) e Paraguai.

Esta espécie foi comumente encontrada no PEVV, tanto no interior e borda da Floresta com Araucária (como terrícola), como nas Formações Areníticas, sobre rochas com acúmulo de húmus. Esta espécie, juntamente com Thelypteris hatschbachii, aparenta ser umas das poucas Pteridófitas que apresentam bom desenvolvimento ao meio de populações da Bambusoidae Merostachys multiramea Hack., freqüentes no PEVV.

\section{Lindsaea Dryand.}

Chave para as espécies de Lindsaea encontradas no PEVV

1. Lâmina 3-4-pinada, últimos segmentos bífidos; soros na terminação de uma ou raramente duas nervura(s)

L. bifida

1. Lâmina 1-2-pinada, pinas ou pínulas não bífidas; soros na terminação de várias nervuras

2. Pinas ou pínulas com venação flabelada

L. botrychioides

2. Pinas ou pínulas com uma nervura principal paralela à margem inferior

3. Pinas ou pínulas com o ápice cuneado e curvado em direção ao ápice da lâmina L. arcuata

3. Pinas ou pínulas com o ápice obtuso ou semi-circular, patente

4. Ápice do pecíolo e/ou base da raque canaliculados apenas na face adaxial, avermelhados em frondes férteis L. quadrangularis subsp. terminalis

4. Ápice do pecíolo e/ou base da raque canaliculados em ambas as faces, estramíneos em frondes férteis

L. lancea

Lindsaea arcuata Kunze, Linnaea 9: 86. 1835.

Material selecionado: 29-X-2005, P.B. Schwartsburd et al. 965 (HUPG, MBM, RB, SP, UPCB).

Distribuição: México (S), Mesoamérica, Grandes Antilhas, Colômbia, Venezuela, Equador, Peru, Bolívia e Brasil (N, SE e S).

Esta espécie foi encontrada como terrícola no interior da Floresta com Araucária, principalmente às margens de riachos e córregos.

Lindsaea bifida (Kaulf.) Mett. ex Kuhn, Chaetopt.: 26. 1882. Davallia bifida Kaulf., Enum. fil.: 222. 1824.

Material selecionado: 5-III-2006, P.B. Schwartsburd et al. 994 (HUPG, MBM, RB, SP, UPCB).

Distribuição: Endêmica ao Brasil (NE, SE e S).

Esta espécie foi encontrada como terrícola e rupícola (humícola), no interior da Floresta com Araucária, principalmente às margens de riachos $\mathrm{e}$ córregos.

Lindsaea botrychioides A. St.-Hil., Voy. Distr. Diam. 1:379. 1833.

Materiais selecionados: 11-X-2003, P.H. Labiak \& P.B. Schwartsburd 2969 (MBM, SP); 10-XI-2003, P.B. Schwartsburd 27 (HUPG, UPCB).

Distribuição: Endêmica às regiões Sul e Sudeste do Brasil.

Esta espécie foi encontrada como terrícola no interior da Floresta com Araucária, mais comumente às margem de córregos e riachos.

Dentre as espécies de Lindsaea que ocorrem no PEVV, L. botrychioides pode ser facilmente distinguida pelos segmentos medianos flabelados, com a margem inferior côncava e o ápice arredondado. 
Lindsaea lancea (L.) Bedd., Ferns Brit. India Suppl.: 6. 1876. Adiantum lancea L., Sp. pl. ed. 2, 2: 1557. 1763.

Material selecionado: 10-XI-2003, P.B. Schwartsburd 28 (HUPG, MBM, UPCB).

Distribuição: México, Mesoamérica, Antilhas, Trinidad, Colômbia, Venezuela, Suriname, Equador, Peru, Bolívia, Brasil (N, NE, CO, SE e S) e Paraguai.

Esta espécie foi encontrada como terrícola no interior da Floresta com Araucária, mais comumente às margens de córregos e riachos.

Lindsaea quadrangularis Raddi subsp. terminalis K.U. Kramer, Acta Bot. Neerl. 6: 192. 1957.

Materiais selecionados: 7-I-2004, P.H. Labiak \& P.B. Schwartsburd 3085 (HUPG, SP); 10-VI-2004, P.B. Schwartsburd \& F.B. Matos 179 (MBM, UPCB).

Distribuição: Brasil (SE e S) e Paraguai.

Esta subespécie foi encontrada como terrícola no interior da Floresta com Araucária, mais comumente às margens de córregos e riachos.

Segundo Kramer (1957) esta espécie ocorre desde o México e Cuba até o Paraguai e Sul do Brasil, não ocorrendo nos Andes. Ainda segundo este autor, a espécie está dividida em quatro subespécies, das quais duas ocorrem no Sul e Sudeste do Brasil.

De acordo com as descrições de Kramer (1957), a principal característica diagnóstica desta subespécie seria o segmento terminal alongado, largo e sorífero. Porém notou-se que, no mesmo indivíduo, as frondes mais desenvolvidas apresentam tal segmento terminal pouco reduzido, e ápice do pecíolo e/ou base da raque avermelhados, enquanto as frondes jovens apresentam os segmentos terminais muito reduzidos e ápice do pecíolo e/ou base da raque estramíneos. Esta variação também foi observada e comentada por Prado (2004b).

\section{Lomagramma J. Sm.}

Lomagramma guianensis (Aubl.) Ching, Amer. Fern J. 22: 17. 1932. Polypodium guianense Aubl., Hist. PL. Guiane 2: 962.1775.

Materiais selecionados: 21-VIII-2004, P.B. Schwartsburd et al. 317 (COR, SP); 14-XII-2004, P.B. Schwartsburd \& F.B. Matos 450 (HUPG, MBM, UPCB).

Distribuição: Grandes Antilhas, Colômbia, Venezuela, Guianas, Peru, Bolívia, Brasil (NE, SE e S) e Argentina.
Esta espécie foi encontrada como hemi-epífita escandente, no interior da Floresta com Araucária.

\section{Lophosoria C. Presl}

Lophosoria quadripinnata (Gmel.) C. Chr., Skottsb. Nat. Hist. Juan Fernandez 1: 16. 1920. Polypodium quadripinnatum Gmel., Syst. Nat. 2(2): 1314. 1791.

Materiais selecionados: 7-I-2004, P.H. Labiak \& P.B. Schwartsburd 3077 (COR, HUPG, SP); 10-VI-2004, P.B. Schwartsburd \& F.B. Matos 171 (UPCB), 172 (MBM); 23-X-2004, P.B. Schwartsburd \& R. Nagata 408 (HUPG); 14-XII-2004, P.B. Schwartsburd \& F.B. Matos 467 (UPCB).

Distribuição: México, Mesoamérica, Grandes Antilhas, Colômbia, Venezuela, Equador, Peru, Bolívia, Brasil (SE e S), Chile (incluindo Ilhas Juan Fernández) e Argentina.

Esta espécie foi encontrada principalmente nos Campos Gerais, freqüentemente na margem de riachos, depressões no solo, cachoeiras, na base de arenitos isolados nos Campos e matas ciliares. Também foi registrada, mais raramente, na borda e interior de matas e ambientes alterados.

\section{Lycopodiella Holub}

Chave para as espécies de Lycopodiella encontradas no PEVV

1. Ramos dorsais dendríticos; estróbilos pendentes L. cernua

1. Ramos dorsais simples; estróbilos eretos

2. Caule anisofilo; ramo dorsal com a superfície aparente, com os microfilos esparsos L. caroliniana

2. Caule isofilo; ramo dorsal com a superfície não aparente, com os microfilos imbricados L. alopecuroides

Lycopodiella alopecuroides (L.) Cranfill, Amer. Fern J. 71: 97. 1981. Lycopodium alopecuroides L., Sp. pl. 2: 1102. 1753.

Material selecionado: 21-XII-2004, P.B. Schwartsburd \& T. Takeuchi 551 (HUPG, MBM, UPCB).

Distribuição: E.U.A. (E), México (S), Mesoamérica, Grandes Antilhas, Colômbia, Venezuela, Equador, Peru, Bolívia, Brasil (N, NE, CO, SE e S), Paraguai e Uruguai. 
Esta espécie foi encontrada como terrícola em terrenos alagadiços dos Campos Gerais, formando densas populações juntamente a populações de Lycopodiella caroliniana e Drosera sp.

Lycopodiella caroliniana (L.) Pic.Serm., Webbia 23: 165. 1968. Lycopodium carolinianum L., Sp. pl. 2: 1104. 1753.

Materiais selecionados: 21-VIII-2004, P.B. Schwartsburd et al. 289 (SP); 21-XII-2004, P.B. Schwartsburd \& T. Takeuchi 550 (HUPG, MBM, UPCB).

Distribuição: África; México, Mesoamérica, Antilhas, Colômbia, Venezuela, Guianas, Equador, Peru, Brasil (N, NE, CO, SE e S) e Uruguai.

Esta espécie foi encontrada como terrícola em terrenos alagadiços dos Campos Gerais, formando densas populações juntamente a populações de Lycopodiella alopecuroides e Drosera sp.

Lycopodiella cernua (L.) Pic.Serm., Webbia 23: 166. 1968. Lycopodium cernuum L., Sp. pl. 2: 1103. 1753.

Materiais selecionados: 7-I-2004, P.H. Labiak \& P.B. Schwartsburd 3067 (HUPG, MBM); 22-XII-2004, P.B. Schwartsburd \& T. Takeuchi 564 (UPCB).

Distribuição: Ásia, Oceania, África; E.U.A., México, Mesoamérica, Antilhas, Trinidad, Colômbia, Venezuela, Guianas, Equador, Peru, Bolívia, Brasil (N, NE, CO, SE e S), Paraguai e Uruguai.

Esta espécie foi encontrada como rupícola e terrícola, no interior de matas alteradas, nas Formações Areníticas e nos Campos Gerais.

Segundo Øllgaard \& Windisch (1987), Lycopodiella camporum B. Øllg. \& P.G. Windisch é uma espécie semelhante e apresenta os ramos primários eretos e os ramos secundários fasciculados e rígidos, enquanto que Lycopodiella cernua apresenta os ramos primários arqueados ou raramente eretos, e os secundários dispersos e laxos.

\section{Lycopodium L.}

Chave para as espécies de Lycopodium encontradas no PEVV

1. Ramos e râmulos complanados e anisofilos L. thyoides

1. Ramos e râmulos com simetria radial e isofilos L. clavatum
Lycopodium clavatum L., Sp. pl. 2: 1101. 1753.

Materiais selecionados: 10-VI-2004, P.B. Schwartsburd \& F.B. Matos 197 (UPCB); 7-I-2005, P.B. Schwartsburd et al. 592 (HUPG); 28-X-2005, P.B. Schwartsburd et al. 957 (MBM).

Distribuição: Europa, Ásia, Ilhas do Pacífico, África; Canadá, E.U.A., México, Mesoamérica, Antilhas, Colômbia, Venezuela, Guianas, Equador, Peru, Bolívia, Brasil (N, SE e S) e Paraguai.

Esta espécie foi encontrada como terrícola nos Campos Gerais, e em bordas de matas alteradas com Pinus spp. e da Floresta com Araucária.

Lycopodium thyoides Humb. \& Bonpl. ex Willd., Sp. pl. ed. 4, 5(1): 18. 1810.

Material selecionado: 21-IX-2005, P.B. Schwartsburd \& R. Moro 889 (HUPG, MBM, UPCB).

Distribuição: México, Mesoamérica, Colômbia, Venezuela, Equador, Peru, Bolívia, Brasil (NE, SE e $\mathrm{S})$ e Argentina $(\mathrm{N})$.

Esta espécie foi encontrada como terrícola nos Campos Gerais, exclusivamente nas regiões mais elevadas, acima de $1.000 \mathrm{~m}$.

De acordo com Nessel (1955) a presente espécie enquadra-se como Lycopodium complanatum L. var. thyoides (Humb. \& Bonpl. ex Willd.) Christ. Porém, de acordo com Øllgaard \& Windisch (1987), Øllgaard (1994) e Mickel \& Smith (2004), L. complanatum é uma espécie do Velho Mundo e L. thyoides, do Novo Mundo. Ainda segundo Mickel \& Smith (2004) este nome é aplicado para um complexo de espécies neotropicais. O complexo L. complanatum foi tratado por Wilce (1965 apud Mickel \& Smith 2004) para o resto do Mundo.

\section{Macrothelypteris (H. Itô) Ching}

Macrothelypteris torresiana (Gaudich.) Ching, Acta Phytotax. Sin. 8(4): 310. 1963. Polystichum torresianum Gaudich. in Freycinet, Voy. Uranie 333. 1828.

Materiais selecionados: 10-XI-2003 P.B. Schwartsburd 26 (MBM, UPCB); 7-I-2004, P.H. Labiak \& P.B. Schwartsburd 3088 (HUPG).

Distribuição: Ásia, Oceania, Ilhas do Pacífico, África; E.U.A. (SE), México (S), Mesoamérica, Antilhas, Colômbia, Venezuela, Equador, Peru, Bolívia, Brasil (NE, CO, SE e S), Paraguai e Argentina (N). 
Esta espécie foi encontrada principalmente como terrícola no interior e borda de matas alteradas com Pinus spp., com Eucalyptus spp. e em ambientes ruderais. Mas também foram encontrados alguns indivíduos às margens da trilha dos arenitos turísticos.

Segundo Smith (1995a) e Mickel \& Smith (2004), este gênero é originário dos Paleotrópicos, com ca. de 10 espécies, sendo Macrothelypteris torresiana a única espécie naturalizada na América.

\section{Marattia Sw.}

Marattia laevis Sm., Pl. Icon. Ined. 2: t. 47. 1790.

Materiais selecionados: 7-I-2004, P.H. Labiak \& P.B. Schwartsburd 3076 (COR, HUPG, SP); 14-XII-2004, P.B. Schwartsburd \& F.B. Matos 447 (UPCB); 12-I-2005, P.B. Schwartsburd \& A.C. Hatschbach 621 (MBM, UPCB).

Distribuição: Grandes Antilhas, Costa Rica, Panamá, Colômbia, Venezuela, Equador, Peru, Bolívia e Brasil (SE e $\mathrm{S}$ ).

Esta espécie foi encontrada principalmente como rupícola nas Formações Areníticas, em ambientes muito sombrios e úmidos. Também encontrada, raramente, como terrícola.

De acordo com as descrições de Sehnem (1967), o presente material enquadra-se como Marattia kaulfussii J. Sm., a qual, segundo Tryon \& Stolze (1989b), é um sinônimo de M. laevis.

\section{Megalastrum Holttum}

Chave para as espécies de Megalastrum encontradas no PEVV

1. Frondes férteis com mais de $2,5 \mathrm{~m}$ compr.; lâmina 3-pinado-pinatissecta na porção mediana M. abundans

1. Frondes férteis com até $1,5 \mathrm{~m}$ compr.; lâmina 2-pinado-pinatissecta na porção mediana M. connexum

Megalastrum abundans (Rosenst.) A.R. Sm. \& R.C. Moran, Amer. Fern. J. 77: 127. 1987. Dryopteris abundans Rosenst., Hedwigia 46: 133. 1906.

Materiais selecionados: 11-X-2003, P.H. Labiak \& P.B. Schwartsburd 2990 (RB, SP); 21-VIII-2004, P.B. Schwartsburd et al. 305 (MBM, SP, UPCB); 8-I-2005, P.B. Schwartsburd et al. 598 (HUPG, UPCB); 602 (HUPG, MBM).
Distribuição: Brasil (S) e Argentina.

Esta espécie foi encontrada como terrícola no interior da Floresta com Araucária, especialmente próxima a riachos e córregos.

Megalastrum connexum (Kaulf.) A.R. Sm. \& R.C. Moran, Amer. Fern. J. 77: 127. 1987. Polypodium connexum Kaulf., Enum. fil.: 120. 1824.

Materiais selecionados: 14-XII-2004, P.B. Schwartsburd \& F.B. Matos 453 (HUPG, MBM, UPCB), 454 (RB); 28-X-2005, P.B. Schwartsburd et al. 962 (UPCB); 29-X-2005, P.B. Schwartsburd et al. 964 (MBM), 972 (SP), 975 (HUPG, MBM, UPCB).

Distribuição: Bolívia, Brasil (SE e S), Paraguai e Uruguai.

Esta espécie foi encontrada como terrícola e rupícola (humícola), no interior da Floresta com Araucária, especialmente próxima a riachos e córregos.

De acordo com o material analisado, esta espécie apresenta uma grande variação morfológica, principalmente quanto ao grau de dissecção na porção proximal da lâmina 2 a 3-pinado-pinatissecta, textura membranácea a cartácea, tricomas presentes ou ausentes sobre a face adaxial das nervuras e os soros amarelos ou castanhos.

Microgramma C. Presl

Chave para as espécies de Microgramma encontradas no PEVV

1. Frondes estéreis com 5-12 cm compr.; costa com escamas peltadas com a margem ciliada e eventualmente também com escamas aracnóides M. squamulosa

1. Frondes estéreis com 2-3,5 cm compr.; costa glabra ou com apenas escamas aracnóides M. vacciniifolia

Microgramma squamulosa (Kaulf.) de la Sota, Opera Lillo. 5: 59. 1961. Polypodium squamulosum Kaulf., Enum. fil.: 89. 1824.

Materiais selecionados: 10-XI-2003, P.B. Schwartsburd 41 (MBM), 42 (COR, SP), 43 (UPCB), 44 (HUPG); 10-VI-2004, P.B. Schwartsburd \& F.B. Matos 204 (UPCB).

Distribuição: Peru, Bolívia, Brasil (CO, SE e S), Paraguai, Argentina e Uruguai. 
Esta espécie foi comumente encontrada no PEVV, principalmente como epífita, mas também como rupícola, sempre formando grandes e densas populações. A ramificação do caule torna difícil a diferenciação entre indivíduo e população. Encontrada no interior e borda da Floresta com Araucária, nas Formações Areníticas, em matas ciliares e em matas alteradas com Pinus spp. e Eucalyptus spp.

Microgramma vacciniifolia (Langsd. \& Fisch.) Copel., Gen. fil.: 185. 1947. Polypodium vacciniifolium Langsd. \& Fisch., Icon. fil.: 8. 1810.

Materiais selecionados: 10-XI-2003, P.B. Schwartsburd 34 (HUPG, MBM, SP), 40 (UPCB).

Distribuição: Antilhas, Venezuela, Colômbia, Peru, Bolívia, Brasil (NE, CO, SE e S), Paraguai, Argentina e Uruguai.

Esta espécie foi encontrada como epífita no interior da Floresta com Araucária e de matas ciliares dos Campos Gerais. Também encontrada como rupícola nas Formações Areníticas, principalmente próximo ao topo dos arenitos.

Nephrolepis Schott

Nephrolepis cordifolia (L.) C. Presl., Tent. Pterid.: 79. 1836. Polypodium cordifolium L., Sp. pl. 2: 1089. 1753.

Materiais selecionados: 15-XII-2003, P.B. Schwartsburd \& A.C. Hatschbach 67 (HUPG, MBM, UPCB), 68 (SP).

Distribuição: Ásia e Oceania; E.U.A. (S), México, Mesoamérica, Antilhas, Colômbia, Venezuela, Guianas, Equador (Galápagos) e Brasil (N, NE, SE e S).

Foi encontrada uma única população desta espécie, crescendo sobre um arenito numa área profundamente antropizada: ponto de recepção aos turistas, nos "arenitos turísticos" do PEVV.

Nephrolepis cordifolia é similar a $N$. pectinata (Willd.) Schott, podendo ser distinguida por apresentar as escamas do caule abundantes, castanho-claras a paleáceas, raque densamente escamosa; em oposição, $N$. pectinata apresenta as escamas do caule escassas, castanho-escuras a negras, raque com as escamas restritas às inserções das pinas (Sehnem 1979b, Nauman 1995). De acordo com estes autores e Tryon \& Stolze (1993), N. pectinata parece ser uma espécie presente apenas no Neotrópico, enquanto que
$N$. cordifolia ocorre tanto na Australásia quanto no Neotrópico. Ambas são cultivadas e também encontradas facilmente em ambientes ruderais da América, porém, aparentemente apenas $N$. pectinata é encontrada em ambientes nativos.

Niphidium J. Sm.

Niphidium crassifolium (L.) Lellinger, Amer. Fern J. 62: 106. 1972. Polypodium crassifolium L., Sp. pl. 2: 1083.1753.

Materiais selecionados: 11-X-2003, P.H. Labiak \& P.B. Schwartsburd 2992 (HUPG, MBM); 21-VIII-2004, P.B. Schwartsburd et al. 279 (UPCB).

Distribuição: México, Mesoamérica, Antilhas, Trinidad, Colômbia, Venezuela, Guianas, Equador, Peru, Bolívia, Brasil (N, NE, SE e S) e Paraguai.

Esta espécie foi encontrada como epífita e rupícola, no interior da Floresta com Araucária e nas Formações Areníticas.

Olfersia Raddi

Olfersia cervina (L.) Kunze, Flora 7: 312. 1824. Osmunda cervina L., Sp. pl. 2: 1065. 1753.

Materiais selecionados: 11-X-2003, P.H. Labiak \& P.B. Schwartsburd 2985 (COR); 7-I-2004, P.H. Labiak \& P.B. Schwartsburd 3075 (HUPG, MBM); 21-VIII-2004, P.B. Schwartsburd et al. 300 (UPCB); 6-III-2005, P.B. Schwartsburd et al. 672 (SP).

Distribuição: México (S), Mesoamérica, Antilhas, Colômbia, Venezuela, Guianas, Equador, Peru, Bolívia e Brasil (N, NE, CO, SE e S).

Esta espécie foi encontrada como rupícola no interior das Formações Areníticas e da Floresta com Araucária, mais comumente às margens de córregos.

\section{Osmunda L.}

Chave para as espécies de Osmunda encontradas no PEVV

1. Frondes hemidimorfas; porção estéril da lâmina 2-pinada ................................ O. regalis

1. Frondes dimorfas; lâmina estéril 1-pinado-pinatissecta ........................ O. cinnamomea

Osmunda cinnamomea L., Sp. pl. 2: 1066. 1753.

Materiais selecionados: 10-VI-2004, P.B. 
Schwartsburd \& F.B. Matos 221 (COR); 21-XII-2004, P.B. Schwartsburd \& T. Takeuchi 553 (HUPG, MBM, UPCB); 9-I-2005, P.B. Schwartsburd et al. 608 (COR).

Distribuição: Ásia (E); Canadá, E.U.A. (C e E), México (S), Mesoamérica, Grandes Antilhas, Bermudas, Colômbia, Venezuela, Equador, Peru, Brasil (SE e S) e Paraguai.

Esta espécie foi encontrada exclusivamente nas regiões de banhado dos Campos Gerais, formando grandes populações juntamente a populações de Osmunda regalis.
Osmunda regalis L., Sp. pl. 2: 1065. 1753.

Materiais selecionados: 22-X-2004, P.B. Schwartsburd \& R. Nagata 351 (HUPG, MBM, SP, UPCB), 353 (COR).

Distribuição: Europa, Ásia, África (S); Canadá (E), E.U.A. (C e E), México, Mesoamérica, Antilhas, Bermudas, Colômbia, Venezuela, Equador, Peru, Brasil (CO, SE e S), Paraguai, Argentina e Uruguai.

Esta espécie foi encontrada exclusivamente nas regiões de banhado dos Campos Gerais, formando grandes populações juntamente a populações de Osmunda cinnamomea.

\section{Pecluma M.G. Price}

Chave para as espécies de Pecluma encontradas no PEVV

1. Nervuras simples

2. Pinas fortemente ascendentes; escamas do caule castanho-escuras P. truncorum

2. Pinas perpendiculares à raque ou levemente ascendentes; escamas do caule ruivas e claras ......P. sicca

1. Nervuras 1 ou mais vezes furcadas

3. Nervuras 1-furcadas

4. Caule delgado, com 1-3 mm diâm., curto-reptante ou ascendente, estolonífero P. singeri

4. Caule crasso, com 7-10 mm diâm., longo-reptante, sem produção de estolões P. pectinatiformis

3. Nervuras 2 ou mais vezes furcadas

5. Lâmina não reduzida na base ou com os dois pares de pinas proximais levemente menores que os acima P. recurvata

5. Lâmina gradual ou abruptamente reduzida na base, com segmentos basais auriculiformes

6. Face abaxial da lâmina com distribuição desigual de tricomas, mais densos nas imediações dos soros; pinas medianas com 8-11 mm larg. P. robusta

6. Face abaxial da lâmina com distribuição homogênea dos tricomas, não densamente hirsuta na proximidade dos soros; pinas medianas com 4-5 mm larg. P. paradiseae

Pecluma paradiseae (Langsd. \& Fisch.) M.G. Price, Amer. Fern J. 73(3): 115. 1983. Polypodium paradisae Langsd. \& Fisch., Icon. fil.: 11. 1810.

Material selecionado: 5-IV-2004, P.B. Schwartsburd \& M. Nogueira Júnior 81 (MBM, UPCB).

Distribuição: Endêmica ao Brasil (N, NE, CO, SE e S). Esta espécie foi raramente encontrada no PEVV, ocorrendo como terrícola no interior de mata ciliar alterada.

Sehnem (1970a) e Athayde Filho \& Windisch (2003) citam esta espécie como ocorrente no México e Antilhas. Porém, de acordo com Evans (1969), esta seria uma espécie endêmica do Brasil, o que é corroborado pelos trabalhos recentes para a flora do México (Mickel \& Beitel 1988, Mickel \& Smith 2004).
Pecluma pectinatiformis (Lindm.) M.G. Price, Amer. Fern J. 73(3): 115. 1983. Polypodium pectinatiforme Lindm., Hedwigia 43: 309. 1904.

Materiais selecionados: 14-XII-2004, P.B. Schwartsburd \& F.B. Matos 434 (MBM); 22-IV-2005, P.B. Schwartsburd et al. 733 (UPCB).

Distribuição: Brasil (NE, SE e S), Paraguai e Argentina.

Esta espécie foi encontrada como epífita no interior da Floresta com Araucária, de matas alteradas com Pinus spp. e de matas ciliares dos Campos Gerais.

Esta espécie é citada para Cuba por Sehnem (1970a) e Athayde Filho \& Windisch (2003), sem indicação de material examinado. Como na espécie anterior, resolveu-se aceitar uma distribuição mais restrita apresentada por Evans (1969) com adição do 
trabalho de Barros et al. (1988).

Pecluma recurvata (Kaulf.) M.G. Price, Amer. Fern J. 73(3): 115. 1983. Polypodium recurvatum Kaulf., Enum. fil.: 106. 1824.

Materiais selecionados: 11-X-2003, P.H. Labiak \& P.B. Schwartsburd 2976 (MBM); 10-XI-2003, P.B. Schwartsburd 4 (HUPG, UPCB); 15-XII-2003, P.B. Schwartsburd \& A.C. Hatschbach 72 (HUPG, RB); 21-VIII-2004, P.B. Schwartsburd et al. 259 (UPCB), 261 (SP), 266 (MBM, SP), 278 (MBM, UPCB).

Distribuição: Pequenas Antilhas, Equador, Brasil (N, NE, SE e S), Paraguai e Argentina.

Esta espécie foi encontrada como epífita e rupícola, no interior da Floresta com Araucária e nas Formações Areníticas.

O material Schwartsburd et al. 278 corresponde a um indivíduo com as pinas pinatissectas, formando lobos irregulares de até 2,1 cm compr. e 3,5 mm larg.; as pinas chegam a apresentar até 10 pares de lobos. Evans (1969) cita a ocorrência destas "anormalidades" para o Paraguai e ainda cita que alguns nomes foram criados para tais espécimes, como Polypodium recurvatum Kaulf var. subbipinnatifidum Rosenst. ex Hassl. Evans (1969) não considera tais espécimes como um táxon distinto de Pecluma recurvata, assim como o presente trabalho.

Pecluma robusta (Fée) M. Kessler \& A.R. Sm., Candollea 60(1): 281.2005. Polypodium robustum Fée, Crypt. Vasc. Brés. 1: 92. 1869.

Material selecionado: 6-IV-2004, P.B. Schwartsburd \& M. Nogueira Júnior 112 (MBM, UPCB).

Distribuição: Peru, Bolívia, Brasil (NE, SE e S), Paraguai, Argentina e Uruguai.

Esta espécie foi raramente encontrada no PEVV, ocorrendo como terrícola no interior da Floresta com Araucária.

Dentre as espécies de Pecluma ocorrentes no PEVV, P. robusta é facilmente reconhecida pelo seu tamanho de até mais de um metro de comprimento e pela formação de "coroas" de tricomas ao redor dos soros. Tais "coroas" também estão presentes em P. ptilodon (Kunze) M.G. Price. Evans (1969) considera $P$. robusta como uma variedade desta última, separando-a principalmente pelo maior porte e pelo lado basiscópico da base das pinas proximais perpendicular à raque. Enquanto que as outras variedades apresentariam tais pinas com o lado basiscópico da base oblíquo à raque.

O presente trabalho, entretanto, aceita a distinção entre essas espécies, conforme recentemente sugerido por Kessler \& Smith (2005).

Pecluma sicca (Lindm.) M.G. Price, Amer. Fern J. 73(3): 115. 1983. Polypodium siccum Lindm., Ark. Bot. 1: 234. 1903.

Materiais selecionados: 5-IV-2004, P.B. Schwartsburd \& M. Nogueira Júnior 91 (HUPG); 10-VI-2004, P.B. Schwartsburd \& F.B. Matos 213 (UPCB); 18-XII-2004, P.B. Schwartsburd et al. 473 (MBM); 7-I-2005, P.B. Schwartsburd et al. 583 (SP).

Distribuição: Brasil (SE e S), Paraguai, Argentina e Uruguai.

Esta espécie foi encontrada como epífita no interior e borda da Floresta com Araucária; também encontrada em matas alteradas com Pinus spp., em estado de regeneração natural.

Pecluma singeri (de la Sota) M.G. Price, Amer. Fern J. 73(3): 115. 1983. Polypodium singeri de la Sota, Opera Lillo. 5: 181. 1960.

Materiais selecionados: 8-IX-2000, S. Dala Rosa 118 (UPCB); 10-II-2001, S. Dala Rosa 136 (UPCB); 11-X-2003, P.H. Labiak \& P.B. Schwartsburd 2968 (HUPG, RB, SP); 15-XII-2003, P.B. Schwartsburd \& A.C. Hatschbach 62 (MBM); 14-XII-2004, P.B. Schwartsburd \& F.B. Matos 436 (UPCB).

Distribuição: Brasil (SE e S), Paraguai e Argentina.

Esta espécie foi encontrada como epífita no interior da Floresta com Araucária.

Dentre as espécies presentes no PEVV, Pecluma sicca é uma das mais semelhantes, podendo ser diferenciada pelas nervuras simples, e não furcadas como em Pecluma singeri.

Pecluma truncorum (Lindm.) M.G. Price, Amer. Fern J. 73(3): 115. 1983. Polypodium truncorum Lindm., Hedwigia 43: 309. 1904.

Material selecionado: 21-VIII-2004, P.B. Schwartsburd et al. 306 (HUPG, MBM, UPCB).

Distribuição: Brasil (SE e S) e Argentina.

Esta espécie foi encontrada no interior da Floresta com Araucária, principalmente em regiões alagadiças ou às margens de córregos, exclusivamente como epífita dos troncos de Alsophila setosa Kaulf. (Cyatheaceae). Esta associação, já bastante citada 
na literatura (Sota 1960, Sehnem 1970a), foi freqüentemente registrada durante este estudo.

Phlebodium (R. Br.) J. Sm.

Phlebodium areolatum (Humb. \& Bonpl. ex Willd.) J. Sm., J. Bot. (Hooker) 4: 59. 1841. Polypodium areolatum Humb. \& Bonpl. ex Willd., Sp. pl. ed. 4, 5: 172.1810.

Materiais selecionados: 10-XI-2003, P.B. Schwartsburd 12 (MBM); 15-XII-2003, P.B. Schwartsburd \& A.C. Hatschbach 66 (HUPG); 7-I-2004, P.H. Labiak \& P.B. Schwartsburd 3051 (MBM, UPCB); 21-VIII-2004, P.B. Schwartsburd et al. 287 (UPCB).

Distribuição: E.U.A. (S), México, Mesoamérica, Antilhas, Colômbia, Venezuela, Guianas, Equador, Peru, Bolívia, Brasil (NE, CO, SE e S), Paraguai e Argentina.

Esta espécie foi encontrada exclusivamente como rupícola nas Formações Areníticas. Sehnem (1970a) também comenta da especificidade desta espécie com rochas areníticas no Sul do Brasil e, como epífita de palmeiras numa localização mais meridional.

Phlebodium areolatum diferencia-se de

P. aureum (L.) J. Sm. e P. decumanum (Willd.) J. Sm., duas espécies semelhantes e com ocorrência no Brasil, pelo menor tamanho das frondes e por apresentar apenas uma série (raramente duas) de soros, entre a costa e a margem da lâmina: P. aureum - 2 a 3 séries, P. decumanum - 3 a 7 séries (Moran 1995c).

Esta espécie é freqüentemente tratada por alguns autores (e.g. Moran 1995c) como Phlebodium pseudoaureum (Cav.) Lellinger. De acordo com Mickel \& Smith (2004), este binômio, apesar de mais antigo, é referente a um tipo estéril e sem indicação da procedência, tornando-se imprecisa sua aplicação até o momento.

\section{Pityrogramma Link}

Pityrogramma trifoliata (L.) R.M. Tryon, Contr. Gray Herb. 189: 68. 1962. Acrostichum trifoliatum L., Sp. pl.: 1070. 1753.

Material selecionado: 22-IV-2005, P.B. Schwartsburd et al. 736 (COR, HUPG, MBM, SP, UPCB).

Distribuição: E.U.A. (S), México, Mesoamérica, Grandes Antilhas, Colômbia, Venezuela, Equador, Peru, Bolívia, Brasil (SE e S), Paraguai, Chile, Argentina (N) e Uruguai.
Esta espécie foi encontrada como terrícola nos Campos úmidos, formando grandes e densas populações. A capacidade de produzir estolões garante a esta espécie uma uma taxa de reprodução vegetativa.

Segundo Tryon \& Stolze (1989a), esta espécie apresenta um alto grau de variação morfológica, com as pinas variando de simples a várias vezes divididas e frondes de 0,5-1,25 m compr. No PEVV os indivíduos desta espécie apresentam as pinas simples a trifoliadas e frondes com até mais de $2 \mathrm{~m}$ compr.

Uma espécie bastante comum em outras regiões do Estado é Pityrogramma calomelanos (L.) Link, a qual difere por apresentar a lâmina 1-pinadopinatífida a 3-pinada; $P$. trifoliata apresenta a lâmina 1-pinada, com as pinas simples a heptafolioladas (Tryon \& Stolze 1989a).

Pleopeltis Humb. \& Bonpl. ex Willd.

Chave para as espécies de Pleopeltis encontradas no PEVV

1. Segmentos fortemente ascendentes, oblíquos cerca de $45^{\circ}$ com a raque; face abaxial do tecido laminar com escamas esparsas, visível ......... P. pleopeltifolia

1. Segmentos perpendiculares à raque; face abaxial do tecido laminar totalmente recoberta pelas escamas, não visível P. squalida

Pleopeltis pleopeltifolia (Raddi) Alston, Bol. Soc. Broteriana 30(2): 21. 1956. Polypodium pleopeltifolium Raddi, Opusc. Sci. Bol. 3: 286. 1819.

Material selecionado: 11-X-2003, P.H. Labiak \& P.B. Schwartsburd 2973 (HUPG); 10-XI-2003, P.B. Schwartsburd 32 (MBM, UPCB); 5-IV-2004, P.B. Schwartsburd \& M. Nogueira Júnior 79 (HUPG), 89 (COR).

Distribuição: Brasil (SE e S), Paraguai, Argentina (NE) e Uruguai $(\mathrm{N})$.

Esta espécie foi encontrada como epífita no interior e borda da Floresta com Araucária, matas alteradas com Pinus spp. e Eucalytptus spp., matas ciliares e também em ambientes ruderais.

Difere de Polypodium typicum Fée e P. pleopeltidis Fée, duas espécies semelhantes, pelos segmentos marcadamente oblíquos à raque, em ângulo 
de aproximadamente $45^{\circ}$ e pela lâmina com aspecto palmatilobado. Polypodium typicum e P. pleopeltidis apresentam os segmentos perpendiculares ou levemente oblíquos à raque, ca. de $70-90^{\circ}$ com a raque e a lâmina não palmatilobada.

Pleopeltis angusta Humb. \& Bonpl. ex Willd., uma espécie frequentemente citada para o Brasil (e.g. Sehnem 1970a, Labiak \& Prado 1998), é bastante semelhante a $P$. pleopeltifolia, diferindo por apresentar o caule delgado, longo-reptante, com as frondes distanciadas entre si, enquanto que em P. pleopeltifolia o caule é crasso, curto-reptante, com as frondes próximas entre si (Sota 1960). Ainda segundo este autor, $P$. angusta não ocorre no Sul da América do Sul, e tais materiais assim tratados corresponderiam a $P$. pleopeltifolia. De acordo com ilustrações apresentadas por Miquel \& Smith (2004), realmente $P$. angusta parece ser uma espécie distinta da ocorrente no PEVV.

Pleopeltis squalida (Vell.) de la Sota, Hickenia 3(47): 195. 2003. Polypodium squalidum Vell., Fl. Flum. 11: t. 76.1836.

Materiais selecionados: 14-XII-2004, P.B. Schwartsburd \& F.B. Matos 432 (HUPG, SP); 7-I-2005, P.B. Schwartsburd et al. 581 (MBM), 582 (UPCB).

Distribuição: Bolívia, Brasil (CO, SE e S), Paraguai, Argentina e Uruguai.

Esta espécie foi raramente encontrada no PEVV, ocorrendo como epífita no interior da Floresta com Araucária, exclusivamente sobre indivíduos de
Araucaria angustifolia (Bertol.) O. Kuntze.

Esta espécie é frequentemente tratada como Polypodium polypodioides (L.) Watt var. minus (Fée) Weath., distinguindo-se das demais variedades deste complexo, em especial Polypodium polypodioides (L.) Watt var. burchellii (Baker) Weath., que ocorre no Brasil, por apresentar porte reduzido (até $10 \mathrm{~cm}$ compr.) e pelas características do indumento (Sota 1960).

\section{Polybotrya Willd.}

Polybotrya cylindrica Kaulf., Enum. fil.: 56. 1824.

Materiais selecionados: 22-XII-2004, P.B. Schwartsburd \& T. Takeuchi 567 (MBM), 568 (UPCB); 21-IV-2005, P.B. Schwartsburd et al. 722 (UPCB).

Distribuição: Endêmica ao Brasil (NE, SE e S).

Esta espécie foi encontrada como hemi-epífita e rupícola, no interior da Floresta com Araucária e nas Formações Areníticas.

Brade (1971) e Sehnem (1979a) consideram duas variedades para a presente espécie: Polybotrya cylindrica var. cylindrica, com pínulas estéreis da $3^{\text {a }}$ categoria de margem lobada e P. cylindrica var. frondosa (Fée) Brade, com pínulas estéreis da $3^{\mathrm{a}}$ categoria pinatissectas. Moran (1987), em sua revisão do gênero, considera $P$. frondosa Fée como sinônimo de $P$. cylindrica, baseando-se na observação de materiais que apresentavam frondes estéreis variando gradualmente de 2-pinada a 3-pinado-pinatífida.

\section{Polypodium L.}

Chave para as espécies de Polypodium encontradas no PEVV

1. Escamas abundantes no tecido laminar

2. Pinas medianas com a margem cartilaginosa e ondulada, ápice arredondado; escamas da face abaxial da lâmina com o ápice medindo aproximadamente 10 vezes a largura da base

P. lepidopteris

2. Pinas medianas com a margem não cartilaginosa e plana, ápice agudo; escamas da face abaxial da lâmina, com o ápice medindo aproximadamente quatro vezes a largura da base

P. hirsutissimum

1. Escamas ausentes no tecido laminar

3. Raque com tricomas, este com aproximadamente $2 \mathrm{~mm}$ compr.; nervuras livres P. chnoophorum

3. Raque glabra ou com tricomas, estes com até $0,5 \mathrm{~mm}$ compr.; nervuras anastomosadas do tipo gonioflebóide 
4. Lâmina pinada; pinas medianas sésseis ou com o lado acroscópico levemente adnado P. meniscifolium

4. Lâmina pinatissecta; segmentos mediandos totalmente adnados em ambos os lados

5. Caule negro e pruinoso; escamas do caule com o ápice medindo aproximadamente 2 vezes a largura da base P. catharinae

5. Caule paleáceo, castanho-claro ou castanho-escuro, não pruinoso; escamas do caule com o ápice medindo até uma vez a largura da base

6. Caule crasso, com 5-10 mm larg., paleáceo ou castanho-claro; lâmina cartácea a subcoriácea; raque com tricomas glandulares e escamas lineares P. vacillans

6. Caule delgado, com 2-5 mm larg., castanho-escuro; lâmina membranácea; raque glabra. P. cf. latissimum

Polypodium catharinae Langsd. \& Fisch., Pl. Voy. Russes Monde: 1. 1810.

Material selecionado: 22-XII-2000, S. Dala Rosa 133 (UPCB); 5-IV-2004, P.B. Schwartsburd \& M. Nogueira Júnior 77 (HUPG, SP), 78 (UPCB); 10-VI-2004, P.B. Schwartsburd \& F.B. Matos 215 (HUPG); 21-VIII-2004, P.B. Schwartsburd et al. 271 (COR, MBM), 282 (HUPG, MBM, UPCB) "forma" do topo dos arenitos; 20-XII-2004, P.B. Schwartsburd \& P. Ambrósio 517 (UPCB).

Distribuição: Brasil (NE, SE e S), Paraguai e Uruguai.

Esta espécie foi encontrada como epífita no interior da Floresta com Araucária e também como rupícola do topo das Formações Areníticas e de arenitos isolados nos Campos Gerais.

Os espécimes do topo dos arenitos (ambientes constantemente ensolarados e com ausência de terra) são de menor tamanho, portando frondes férteis com 25-40 cm compr. e 7-11 cm larg., apresentam as escamas do caule um pouco menos acuminadas e as pinas voltadas para trás com o ápice arredondado. Esta variação morfológica está representada no material Schwartsburd et al. 282.

Os espécimes de Polypodium meniscifolium Langsd. \& Fisch. ocorrentes no mesmo ambiente são bastante semelhantes no que se refere às características acima mencionadas. No entanto, podem ser diferenciados pelo grau de dissecção da lâmina: pinatissecta em $P$. catharinae e pinada em $P$. meniscifolium.

Polypodium chnoophorum Kunze, Flora 1839(1): 34. 1839.

Materiais selecionados: 14-XII-2004, P.B. Schwartsburd \& F.B. Matos 457 (MBM), 459 (UPCB), 460 (HUPG).
Distribuição: Brasil (NE, SE e S), Paraguai e Argentina.

Esta espécie foi raramente encontrada no PEVV, ocorrendo como rupícola no interior da Floresta com Araucária, em regiões próximas às Formações Areníticas.

Diferencia-se das demais espécies de Polypodium, ocorrentes no PEVV, pelos tricomas com mais de $2 \mathrm{~mm}$ compr., pluricelulares e lineares, abundantes no pecíolo e raque, caule comumente verde e as nervuras não anastomosadas.

Polypodium hirsutissimum Raddi, Opusc. Sci. Bol. 3: 286.1819.

Materiais selecionados: 8-IX-2000, S. Dala Rosa 115 (UPCB); 11-X-2003, P.H. Labiak \& P.B. Schwartsburd 2959 (HUPG); 16-V-2005, P.B. Schwartsburd \& M. Nogueira Júnior 803 (MBM); 17-V-2005, P.B. Schwartsburd \& M. Nogueira Júnior 821 (UPCB).

Distribuição: Brasil (NE, CO, SE e S), Paraguai, Argentina e Uruguai.

Esta espécie foi encontrada como epífita no interior e borda da Floresta com Araucária, matas alteradas com Pinus spp. e Eucalyptus spp., e também em áreas antropizadas com na Vila do IAPAR.

Diferencia-se de Polypodium lepidopteris, a espécie mais semelhante, por apresentar hábito predominantemente epifítico, com as frondes arqueadas e próximas entre si, caule geralmente crasso e escamas da face abaxial da lâmina geralmente com o ápice avermelhado. Polypodium lepidopteris apresenta o hábito terrícola ou rupícola, com as frondes eretas e espaçadamente distribuídas, caule delgado e escamas da face abaxial da lâmina geralmente com o ápice esbranquiçado. 
Polypodium cf. latissimum R.C. Moran \& B. Øllg., Nordic J. Bot. 15(2): 184. 1995.

Materiais selecionados: 21-IV-2005, P.B. Schwartsburd et al. 719 (SP), 720 (UPCB); 5-III-2006, P.B. Schwartsburd et al. 996 (HUPG, MBM).

Distribuição: Equador, Peru, Bolívia e Brasil (S).

Esta espécie foi raramente encontrada no PEVV, ocorrendo como terrícola no interior da Floresta com Araucária, próxima a nascentes d'água e córregos.

Apesar dos materiais do PEVV se enquadrarem no conceito de Polypodium latissimum, resolveu-se por manter o satus de $c f$. para eles, tendo em vista a enorme lista de sinônimos de Polypodium catharinae e Polypodium latipes Langsd. \& Fisch. citados por Hensen (1990).

Polypodium lepidopteris (Langsd. \& Fisch.) Kunze, Linnaea 13: 132. 1836. Acrostichum lepidopteris Langsd. \& Fisch., Pl. Voy. Russes Monde: 5. 1810. Materiais selecionados: 11-X-2003, P.H. Labiak \& P.B. Schwartsburd 2965 (HUPG, MBM, SP, UPCB); 10-XI-2003, P.B. Schwartsburd 5 (MBM, UPCB); 5-III-2006, P.B. Schwartsburd et al. 1001 (HUPG, MBM, SP), 1003 (UPCB), 1006 (RB).

Distribuição: Brasil (NE, SE e S) e Uruguai.

Esta espécie foi encontrada exclusivamente nas áreas mais elevadas do PEVV: $1.000 \mathrm{~m}$ ou acima. Foi encontrada tanto como terrícola nos Campos Gerais, como rupícola do topo das Formações Areníticas e de arenitos isolados nos Campos.

Segundo Sota (1965) esta é uma espécie preferencialmente litorânea, das restingas, com dúvidas acerca de seu registro para o interior do Continente. O presente trabalho registrou esta espécie cerca de $200 \mathrm{~km}$ da costa e $1.050 \mathrm{~m}$ de altitude, em ambiente relativamente similar à restinga, qual seja, heliófilo e solo arenoso.

Polypodium meniscifolium Langsd. \& Fisch., Pl. Voy. Russes Monde: 11. 1810.

Materiais selecionados: 10-XI-2003, P.B. Schwartsburd 13 (HUPG, MBM, UPCB) - "forma" do topo dos arenitos; 21-VIII-2004, P.B. Schwartsburd et al. 260 (SP), 262 (HUPG); 19-XII-2004, P.B. Schwartsburd et al. 508 (HUPG, UPCB); 29-X-2005, P.B. Schwartsburd et al. 988 (UPCB).
Distribuição: Endêmica ao Brasil (NE, SE e S).

Esta espécie foi encontrada como terrícola, epífita e rupícola, na borda e interior da Floresta com Araucária e no interior das Formações Areníticas. Também encontrada como rupícola no topo das Formações Areníticas e de arenitos isolados nos Campos Gerais.

Da mesma forma que alguns espécimes de Polypodium catharinae, os de P. meniscifolium encontrados no topo dos arenitos (Schwartsburd 13) apresentam as frondes eretas, menores (frondes férteis com 40-45 cm compr. e 17-20 cm larg.) e com as pinas voltadas para trás. Tal é a variação morfológica encontrada entre os indivíduos ocorrentes em hábitats distintos, que algumas espécies foram descritas baseadas nestas diferenças (e.g. Polypodium gauthierii (Fée) C. Chr.). Realmente, as diferenças morfológicas que separam estas duas espécies parecem ser resultantes da adaptação a ambientes muito diferenciados, conforme observado nas populações do PEVV.

Uma das espécies mais semelhantes a Polypodium meniscifolium é $P$. triseriale Sw., a qual pode ser distinguida por apresentar a lâmina coriácea, com 5 a no máximo 15 pares de pinas, estas sem pontuações glaucas na face adaxial. Polypodium meniscifolium apresenta a lâmina cartácea, com 15 a 30 pares de pinas com pontuações glaucas na face adaxial.

Polypodium vacillans Link, Hort. Berol. 2: 97. 1833.

Materiais selecionados: 7-I-2004, P.H. Labiak \& P.B. Schwartsburd 3059 (HUPG); 5-IV-2004, P.B. Schwartsburd \& M. Nogueira Júnior 90 (MBM); 6-IV-2004, P.B. Schwartsburd \& M. Nogueira Júnior 107 (SP); 10-VI-2004, P.B. Schwartsburd \& F.B. Matos 199 (HUPG), 212 (RB); 19-XII-2004, P.B. Schwartsburd et al. 495 (UPCB); 23-IV-2005, P.B. Schwartsburd et al. 740 (HUPG, UPCB).

Distribuição: Bolívia, Brasil (S) e Paraguai.

Esta espécie foi comumente encontrada no Parque, ocorrendo como terrícola dos Campos Gerais, formando grandes e densas populações. Também encontrada na borda da Floresta com Araucária. Polypodium vacillans aprenta ser uma das espécies de Pteridófitas mais frequientes nos Campos Gerais.

Distingue-se de Polypodium catharinae e $P$. latipes Langsd. \& Fisch., pela presença de tricomas e escamas filiformes sobre a raque. Embora 
Hensen (1990) cite a ocorrência de tricomas sobre a raque de $P$. latipes, a análise de materiais oriundos do litoral e da Floresta Atlântica demonstrou a ausência de indumento no que tradicionalmente se tem considerado como P. latipes. Os materiais de Vila Velha claramente apresentam indumento constituído por tricomas glandulares e pequenas escamas filiformes esparsas, principalmente sobre a raque. Por esse motivo, optou-se em nominar os materiais do PEVV como $P$. vacillans, considerando o indumento uma característica importante na delimitação destas espécies.

Polystichum Roth, nom. cons.

Polystichum montevidense (Spreng.) Rosenst., Hedwigia 46: 111. 1906. Polypodium montevidense Spreng., Syst. Veg. ed. 16, 4: 59. 1827.

Materiais selecionados: 11-X-2003, P.H. Labiak \& P.B. Schwartsburd 2984 (HUPG, MBM, UPCB); 6-IV-2004, P.B. Schwartsburd \& M. Nogueira Júnior 106 (HUPG, UPCB); 29-X-2005, P.B. Schwartsburd et al. 970 (MBM, UPCB).

Distribuição: Colômbia, Venezuela, Peru, Bolívia, Brasil (SE e S), Argentina e Uruguai.

Esta espécie foi encontrada como terrícola no interior da Floresta com Araucária, principalmente em áreas adjacentes a córregos ou em regiões da baixada. Também encontrada como rupícola (humícola) nas Formações Areníticas.

Apesar do material examinado apresentar uma grande variação morfológica, principalmente quanto às medidas da fronde, pínulas e o grau de indumento da raque, não se conseguiu delimitar características morfológicas concisas que pudessem separá-los em outros táxons. Sehnem (1979a) também comenta sobre esta dificuldade, mas considera tais variações como espécies distintas.

\section{Polytaenium Desv.}

Polytaenium lineatum (Sw.) J. Sm., J. Bot. (Hooker) 4: 68. 1841. Hemionitis lineata Sw., Prodr.: 129. 1788.

Material selecionado: 15-VIII-1990, J.M. Silva \& I. Rauscher 881 (UPCB).

Distribuição: México (S), Mesoamérica, Grandes Antilhas, Trinidad, Colômbia, Venezuela, Guianas, Equador, Peru, Bolívia, Brasil (NE, SE e S) e Argentina (NO).

Esta espécie não foi encontrada durante as coletas deste trabalho, tendo seu registro a partir de coletas anteriores. Segundo as informações de coleta, esta espécie ocorre no PEVV como epífita no interior da Floresta com Araucária.

Pteridium Gled. ex Scop., nom. cons.

Pteridium arachnoideum (Kaulf.) Maxon, J. Wash. Acad. Sci. 14: 89. 1924. Pteris arachnoidea Kaulf., Enum. fil.: 190. 1824.

Materiais selecionados: 15-XII-2003, P.B. Schwartsburd \& A.C. Hatschbach 58 (HUPG, UPCB); 5-III-2006, P.B. Schwartsburd et al. 1008 (HUPG, UPCB).

Distribuição: México, Mesoamérica, Antilhas, Trinidad, Colômbia, Venezuela, Guianas, Equador, Peru, Bolívia, Brasil (N, NE, CO, SE e S), Paraguai, Argentina (N) e Uruguai.

Esta espécie é uma das mais comuns dos Campos Gerais e, aparentemente, em biomassa, a mais numerosa no PEVV. A faculdade do caule em se ramificar garante a formação de grandes e densas populações, principalmente nas regiões mais secas dos Campos. Pteridium arachnoideum foi encontrada também em matas alteradas com Pinus spp. e Eucalyptus spp. e dentro de pequenos "capões" de Floresta com Araucária.

\section{Pteris L.}

Chave para as espécies de Pteris encontradas no PEVV

1. Lâmina 1-pinada

2. Lâmina com a base gradualmente reduzida; nervuras livres P. vittata

2. Lâmina com a base não reduzida; nervuras anastomosadas P. splendens

1. Lâmina 1-pinado-pinatífida ou mais dividida

3. Lâmina 2-3-pinado-pinatissecta; nervuras livres P. deflexa

3. Lâmina 1-2-pinado-pinatissecta; nervuras anastomosadas

4. Lâmina conspicuamente pilosa, tricomas seríceos .... P. lechleri

4. Lâmina glabra ou esparsamente pilosa, tricomas alvos $P$. decurrens 
Pteris decurrens C. Presl, Del. Prag. 1: 183. 1822.

Materiais selecionados: 21-VIII-2004, P.B. Schwartsburd et al. 298 (HUPG, MBM, SP, UPCB); 29-X-2005, P.B. Schwartsburd et al. 961 (MBM, UPCB).

Distribuição: Colômbia, Venezuela, Peru, Bolívia, Brasil (SE e S) e Chile.

Esta espécie foi encontrada no interior da Floresta com Araucária, como rupícola (humícola) e terrícola.

Dentre as espécies semelhantes, principalmente pela arquitetura foliar, pode-se citar Pteris lechleri Mett. e P. biaurita L. Porém, P. lechleri apresenta a lâmina conspicuamente pilosa, e Pteris decurrens apresenta a lâmina glabra ou com tricomas esparsos. Segundo Prado \& Windisch (2000), Pteris biaurita apresenta apenas uma aréola entre cóstulas adjacentes, já $P$. decurrens apresenta duas (ou raramente três) aréolas entre cóstulas adjacentes.

Pteris deflexa Link, Hort. Berol. 2: 30. 1833.

Materiais selecionados: 7-I-2004, P.H. Labiak \& P.B. Schwartsburd 3054 (HUPG, MBM, UPCB); 5-IV-2004, P.B. Schwartsburd \& M. Nogueira Júnior 94 (SP).

Distribuição: Grandes Antilhas, Colômbia, Venezuela, Equador, Peru, Bolívia, Brasil (NE, CO, SE e S), Paraguai, Argentina e Uruguai.

Esta espécie foi encontrada no interior da Floresta com Araucária, como terrícola.

Pteris deflexa pode ser facilmente distinguida das outras espécies do gênero, ocorrentes no PEVV, pelas frondes com mais de $2 \mathrm{~m}$ compr. e pelo caule com mais de $3 \mathrm{~cm}$ diâm.

Pteris lechleri Mett., Fil. Lechl. 2: 13. 1859.

Materiais selecionados: 15-IV-1992, J. Cislinki \& A.C. Cervi 142 (UPCB); 10-XI-2003, P.B. Schwartsburd 1 (MBM, SP, UPCB); 21-VIII-2004, P.B. Schwartsburd et al. 280 (HUPG).;

Distribuição: Panamá, Colômbia, Equador, Peru, Bolívia e Brasil (SE e S).

Esta espécie foi encontrada nas Formações Areníticas e no interior da Floresta com Araucária, tanto como terrícola como rupícola humícola e de frestas.

Pteris splendens Kaulf., Enum. fil.: 186. 1824.
Materiais selecionados: 21-VIII-2004, P.B. Schwartsburd et al. 319 (HUPG, MBM, SP, UPCB); 21-IV-2005, P.B. Schwartsburd et al. 709 (UPCB).

Distribuição: Brasil (NE, SE e S) e Paraguai.

Esta espécie foi encontrada no interior da Floresta com Araucária, principalmente como rupícola ou eventualmente terrícola, próxima a riachos.

Pteris vittata L., Sp. pl. 2: 1074. 1753.

Material selecionado: 7-I-2004, P.H. Labiak \& P.B. Schwartsburd 3094 (HUPG, MBM, UPCB).

Distribuição: Ásia, Oceania e África; E.U.A. (SE, S e O), México, Mesoamérica, Antilhas, Trinidad, Venezuela, Guiana, Peru, Brasil (N, NE, CO, SE e S) e Argentina.

Esta espécie foi encontrada exclusivamente em ambientes ruderais, tais como muros e calçadas, frequientemente expostas ao sol constante.

Segundo Prado \& Windisch (2000) e Tryon \& Stolze (1989a), Pteris vittata é uma espécie exótica e introduzida na América. Esta espécie parece ocorrer espontaneamente no Brasil, principalmente em áreas urbanas ou antropizadas. No Estado do Paraná, principalmente no litoral, $1^{\circ}$ e $2^{\circ}$ Planaltos, esta espécie aparenta ser um dos principais elementos pteridofíticos de ambientes ruderais (observações pessoais).

\section{Rumohra Raddi}

Rumohra adiantiformis (G. Forst.) Ching, Sinensia 5: 70. 1934. Polypodium adiantiforme G. Forst., Prodr.: 82. 1786.

Materiais selecionados: 11-X-2003, P.H. Labiak \& P.B. Schwartsburd 2988 (HUPG); 15-XII-2003, P.B. Schwartsburd \& A.C. Hatschbach 56 (MBM, HUPG); 6-III-2005, P.B. Schwartsburd et al. 682 (UPCB); 29-X-2005, P.B. Schwartsburd et al. 986 (MBM, UPCB).

Distribuição: Ásia, Oceania e África; Bermudas, Grandes Antilhas, Equador (Galápagos), Peru, Brasil (NE, CO, SE e S), Chile (incluindo Ilhas Juan Fernández), Argentina (incluindo as Malvinas) e Uruguai.

Popularmente conhecida como samambaia preta e muito utilizada em arranjos florais, esta espécie foi comumente encontrada no PEVV, em ambientes tanto heliófilos quanto ombrófilos. Foi encontrada como terrícola e rupícola nos Campos, bordas da Floresta 
com Araucária, matas alteradas com Eucalyptus spp., no topo das Formações Areníticas e em ambientes alterados. Apesar desta espécie ser comumente encontrada como epífita no litoral e Serra do Mar do
Estado do Paraná (observações pessoais) e no litoral de Santa Catarina (Sehnem 1979a, Labiak \& Prado 1998), no PEVV ela só foi visualizada como terrestre e rupícola.

\section{Selaginella Beauv., nom. cons.}

Chave para as espécies de Selaginella encontradas no PEVV

1. Rizóforos partindo da face dorsal do caule; microfilos dorsais com o ápice acuminado S. marginata

1. Rizóforos partindo da face ventral do caule ou em ambas as faces; microfilos dorsais com ápice aristado

2. Hábito nitididamente ereto; rizóforos restritos à base do caule; microfilos dorsais com arista menor que $1 / 2$ do tamanho do microfilo S. decomposita

2. Hábito reptante ou prostrado; rizóforos presentes ao longo de todo o caule; microfilos dorsais com arista maior que $1 / 2$ do tamanho do microfilo

3. Hábito prostrado; face adaxial dos microfilos laterais rugosa e com os cloroplastos pouco aparentes; estróbilo quadrangular

S. flexuosa

3. Hábito reptante; face adaxial dos microfilos laterais lisa e com os cloroplastos nitidamente evidentes; estróbilo complanado S. $m u s c o s a$

Selaginella decomposita Spring in Mart., Fl. Bras. 1(2): 123.1840.

Materiais selecionados: 10-VI-2004, P.B. Schwartsburd \& F.B. Matos 247 (UPCB), 248 (COR), 249 (RB), 250 (SP), 251 (HUPG), 254 (MBM); 22-XII-2004, P.B. Schwartsburd \& T. Takeuchi 563 (UPCB).

Distribuição: Endêmica ao Brasil (NE, SE e S).

Esta espécie foi encontrada como rupícola nas Formações Areníticas e no interior da Furna I, próxima à lâmina d'água.

Selaginella flexuosa Spring, Flora 21: 197. 1838.

Materiais selecionados: 21-IV-2005, P.B. Schwartsburd et al. 706 (HUPG); 16-V-2005, P.B. Schwartsburd \& M. Nogueira Júnior 789 (HUPG); 28-X-2005, P.B. Schwartsburd et al. 951 (UPCB).

Distribuição: Endêmica ao Brasil (NE, CO, SE e S).

Esta espécie foi encontrada como rupícola e terrícola, no interior da Floresta com Araucária e nas Formações Areníticas.

Segundo Hirai \& Prado (2000) a aparência rugosa dos microflios é característica exclusiva dentre as espécies de São Paulo, o que também é observado nos táxons do PEVV.
Selaginella marginata (Humb. \& Bonpl. ex Willd.) Spring, Flora 21: 194. 1838. Lycopodium marginatum Humb. \& Bonpl. ex Willd., Sp. pl. 5: 41. 1810.

Materiais selecionados: 7-I-2004, P.H. Labiak \& P.B. Schwartsburd 3097 (HUPG, MBM, RB, SP, UPCB); 21-VIII-2004, P.B. Schwartsburd et al. 293 (MBM); 23-X-2004, P.B. Schwartsburd \& R. Nagata 422 (UPCB).

Distribuição: México (C), Grandes Antilhas, Venezuela, Bolívia, Brasil (NE, CO, SE e S), Paraguai, Argentina e Uruguai.

Esta espécie foi encontrada como rupícola e terrícola, no interior da Floresta com Araucária, nos Campos às margem de córregos, e no topo das Formações Areníticas em micro-hábitats úmidos.

Selaginella muscosa Spring in Mart., Fl. Bras. 1(2): 120. 1840.

Material selecionado: 10-XI-2003, P.B. Schwartsburd 20 (UPCB).

Distribuição: Trinidad \& Tobago, Colômbia, Venezuela, Guiana, Peru, Brasil (N, NE, SE e S), Paraguai, Argentina e Uruguai.

Esta espécie foi encontrada como rupícola nas margens de córregos do interior da Floresta com Araucária. 
Sticherus C. Presl

Chave para as espécies de Sticherus encontradas no PEVV

1. Frondes com menos de $1 \mathrm{~m}$ compr.; caule com menos de $2 \mathrm{~mm}$ larg.; segmentos menos de três vezes mais compridos que largos S. pruinosus

1. Frondes com mais de $1 \mathrm{~m}$ compr.; caule com mais de $4 \mathrm{~mm}$ larg.; segmentos mais de quatro vezes mais compridos que largos

2. Frondes eretas; ramos fortemente imbricados; ápice dos ramos jovens com denso indumento alvo; gemas com escamas esbranquiçadas S. lanuginosus

2. Frondes comumente arqueadas; ramos não imbricados; ápice dos ramos sem indumento denso; gemas com escamas castanhoclaras S. bifidus

Sticherus bifidus (Willd.) Ching, Sunyatsenia 5: 282. 1940. Mertensia bifida Willd., Kongl. Vetensk. Acad. Handl.: 168. 1804.

Materiais selecionados: 10-VI-2004, P.B. Schwartsburd \& F.B. Matos 182 (UPCB); 20-XII-2004, P.B. Schwartsburd \& P. Ambrósio 516 (UPCB); 17-V-2005, P.B. Schwartsburd \& M. Nogueira Júnior 818 (HUPG, MBM, RB, SP).

Distribuição: México (S), Mesoamérica, Antilhas, Trinidad, Colômbia, Venezuela, Guiana, Equador, Peru, Bolívia, Brasil (SE e S) e Paraguai.

Esta espécie foi encontrada como terrícola, tanto no interior da Floresta com Araucária como nos Campos Gerais, porém exclusivamente próxima a córregos e cachoeiras, com as frondes comumente arqueadas.

Sticherus lanuginosus (Fée) Nakai, Bull. Nat. Sci. Mus. 29: 20. 1950. Gleichenia lanuginosa Fée, Crypt. Vasc. Brés. 1: 202. 1869.

Materiais selecionados: 20-XII-2004, P.B. Schwartsburd \& P. Ambrósio 515 (COR); 21-XII-2004, P.B. Schwartsburd \& T. Takeuchi 538
(HUPG); 19-X-2005, P.B. Schwartsburd et al. 935 (UPCB).

Distribuição: Costa Rica, Colômbia, Venezuela, Equador, Peru, Bolívia, Brasil (NE, CO, SE e S), Paraguai e Uruguai.

Esta espécie foi comumente encontrada no PEVV, principalmente como terrícola dos Campos Gerais e em áreas alteradas. Nos Campos, principalmente nas áreas secas, esta espécie forma grandes e densas populações com as frondes eretas, equiparando o hábito a Pteridium arachnoideum.

Sticherus pruinosus (Mart.) Ching, Sunyatsenia 5(4): 284. 1940. Mertensia pruinosa Mart., Icon. Pl. Crypt. 109. 1834.

Materiais selecionados: 10-XI-2003, P.B. Schwartsburd 19 (MBM, UPCB); 16-V-2005, P.B. Schwartsburd \& M. Nogueira Júnior 794 (MBM, UPCB).

Distribuição: Endêmica às regiões Sul e Sudeste do Brasil.

Esta espécie está aparentemente restrita às regiões mais elevadas do PEVV, tendo sido encontrada principalmente como rupícola de córregos e cachoeiras dos Campos Gerais, com as frondes arqueadas.

Sticherus pruinosus é bastante semelhante a $S$. revolutus (Kunth) Ching, distinguindo-se por apresentar as frondes não escandentes, com até $1 \mathrm{~m}$ compr. Sticherus revolutus apresenta as frondes escandentes, com vários metros de comprimento (Gonzáles, dados não publicados).

Terpsichore A.R. Sm.

Terpsichore reclinata (Brack.) Labiak, Brittonia 52(3): 253. 2000. Polypodium reclinatum Brack., U.S. Expl. Exp. Filic. 16: 11. 1854.

Material selecionado: 19-X-2005, P.B. Schwartsburd et al. 929 (UPCB).

Distribuição: Endêmica às regiões Sul e Sudeste do Brasil.

Esta espécie foi raramente encontrada no PEVV, ocorrendo como rupícola nas Formações Areníticas, em associação com espécies de Hymenophyllum. 
Thelypteris Schmidel, nom. cons.

Chave para os subgêneros de Thelypteris encontrados no PEVV

1. Nervuras proximais anastomosadas, as acima livres Cyclosorus

1. Todas as nervuras livres

2. Lâmina com a base não reduzida ou com apenas um ou dois pares de pinas levemente menores que as acima, não auriculiformes Steiropteris

2. Lâmina com a base gradual ou abruptamente reduzida, com pinas basais auriculiformes Amauropelta

Thelypteris subg. Amauropelta (Kunze) A.R. Sm.

Chave para as espécies de Thelypteris subg. Amauropelta encontradas no PEVV

1. Caule longo-reptante T. rivularioides

1. Caule ereto ou decumbente

2. Pinas pecioluladas T. ptarmica

2. Pinas sésseis

3. Lâmina sem tricomas uncinados na face abaxial; indúsio fixo lateralmente T. decurtata

3. Lâmina com tricomas uncinados na face abaxial; indúsio peltado ou ausente

4. Raque com tricomas unicelulares exclusivamente; soros alongados; indúsio ausente

4. Raque com tricomas pluricelulares e unicelulares; soros arredondados; indúsio presente

5. Lâmina com gemas prolíferas na base das pinas distais; segmentos com nervuras basais e medianas soríferas T. araucariensis

5. Lâmina sem gemas prolíferas; segmentos comumente com apenas o par de nervuras proximal sorífero T. retusa

Thelypteris amambayensis (H. Christ) Ponce, Candollea 55: 310. 2000. Dryopteris amambayensis H. Christ, Repert. Spec. Nov. Regni Veg. 7: 374. 1909.

Materiais selecionados: 7-I-2004, P.H. Labiak \& P.B. Schwartsburd 3048 (HUPG, MBM, UPCB); 10-VI-2004, P.B. Schwartsburd \& F.B. Matos 205 (SP); 18-XII-2004, P.B. Schwartsburd et al. 474 (SP); 22-IV-2005, P.B. Schwartsburd et al. 728 (MBM).

Distribuição: Brasil (SE e S), Paraguai e Argentina.

Esta espécie foi encontrada como terrícola e epífita acidental no interior da Floresta com Araucária, e como rupícola (humícola) nas Formações Areníticas.

Dentre as espécies de Thelypteris ocorrentes no PEVV, T. amambayensis e T. araucariensis são as únicas que apresentam gemas prolíferas na lâmina. Estas duas espécies podem ser diferenciadas entre si pelas características apresentadas na chave.

Thelypteris araucariensis Ponce, Darwiniana 33: 270. 1995.
Material selecionado: 6-IV-2004, P.B. Schwartsburd \& M. Nogueira Júnior 103 (UPCB).

Distribuição: Endêmica às regiões Sul e Sudeste do Brasil.

Esta espécie foi encontrada como terrícola no interior da Floresta com Araucária.

Thelypteris decurtata (Link) de la Sota, Lilloa 36(1): 65. 1983. Asplenium decurtatum Link, Fil. Spec. 94. 1841.

Materiais selecionados: 22-IV-2005, P.B. Schwartsburd et al. 729 (HUPG, MBM, SP, UPCB).

Distribuição: Brasil (SE e S), Paraguai, Argentina e Uruguai.

Esta espécie foi encontrada como terrícola no interior da Floresta com Araucária e de matas alteradas com Pinus spp., especialmente em áreas encharcadas.

Thelypteris decurtata distingue-se das demais espécies do gênero, presentes no PEVV, por apresentar os soros lineares com o indúsio fixo 
lateralmente e o caule subarborescente e massivo, formado pela compactação das raízes. As outras espécies com indúsio encontradas no PEVV, apresentam o indúsio reniforme e não formam caules massivos.

Thelypteris ptarmica (Kunze ex Mett.) C.F. Reed, Phytologia 17: 307. 1968. Aspidium ptarmicum Kunze ex. Mett., Abh. Senckenberg. Naturf. Ges. 2: 364.1858 .

Materiais selecionados: 10-XI-2003, P.B. Schwartsburd 17 (HUPG, MBM, UPCB); 17-V-2005, P.B. Schwartsburd \& M. Nogueira Júnior 817 (SP, UPCB).

Distribuição: Endêmica ao Brasil (CO, SE e S).

Esta espécie foi encontrada como rupícola de cachoeiras e riachos, tanto no interior da Floresta com Araucária como nos Campos Gerais.

Dentre as espécies que ocorrem no PEVV, Thelypteris ptarmica pode ser facilmente distinguida pelas pinas nitidamente pecioluladas (2-3 mm compr.), além do hábitat e hábito exclusivos.

De acordo com as considerações de Ponce (1995) e Salino \& Semir (2004), duas variedades são dinstinguíveis para esta espécie: Thelypteris ptarmica var. ptarmica, que possuem soros com indúsio, e T. ptarmica var. asplenioides ( $\mathrm{Sw}$ ) Ponce com soros sem indúsio. $\mathrm{O}$ material do PEVV enquadra-se na variedade típica da espécie

Thelypteris retusa (Sw.) C.F. Reed, Phytologia 17: 309.1968. Polypodium retusum Sw., Kongl. Vetensk. Acad. Handl.: 61. 1817.

Materiais selecionados: 12-I-2005, P.B. Schwartsburd \& A.C. Hatschbach 620 (UPCB); 16-V-2005, P.B. Schwartsburd \& M. Nogueira Júnior 793 (MBM).

Distribuição: Endêmica ao Brasil (NE, SE e S).

Esta espécie foi encontrada no PEVV como terrícola, apenas no interior de matas alteradas com Eucalyptus spp.

Thelypteris rivularioides (Fée) Abbiatti, Rev. Mus. La Plata, Secc. Bot. 9: 19. 1958. Aspidium rivularioides Fée, Crypt. Vasc. Brés. 1: 145. 1869.

Materiais selecionados: 7-I-2004, P.H. Labiak \& P.B. Schwartsburd 3056 (HUPG, MBM, UPCB); 6-IV-2004, P.B. Schwartsburd \& M. Nogueira Júnior 100 (HUPG); 23-X-2004, P.B. Schwartsburd \& R. Nagata 352 (SP), 362 (BHCB, MBM, UPCB);
29-X-2005, P.B. Schwartsburd et al. 939 (MBM, UPCB), 984 (SP).

Distribuição: Brasil (CO, SE e S), Paraguai, Argentina (N e O) e Uruguai.

Esta espécie foi encontrada como terrícola próxima a córregos e em áreas alagadas, principalmente nos Campos Gerais, mas também encontrada em matas alteradas com Eucalyptus spp.

Thelypteris rivularioides se caracteriza pelo caule longo-reptante, com as frondes lateralmente dispostas, o que a diferencia das espécies mais semelhantes do PEVV, T. araucariensis e T. retusa.

Thelypteris subg. Cyclosorus (Link) C.V. Morton

Chave para as espécies de Thelypteris subg. Cyclosorus encontradas no PEVV

1. Caule negro, glabro, longo-reptante, ramificado, com as frondes mais de $4 \mathrm{~cm}$ espaçadas entre si T. interrupta

1. Caule marrom, com escamas, ereto ou curto-reptante, indiviso, com as frondes menos de $3 \mathrm{~cm}$ espaçadas entre si

2. Tricomas da raque septados, com $1 \mathrm{~mm}$ compr. ou maiores; nervuras proximais de segmentos adjacentes unindo-se em ângulo agudo na nervura excurrente ou raramente unindo-se diretamente no sinus

T. conspersa

2. Tricomas da raque não septados, com $0,5 \mathrm{~mm}$ compr. ou menores; nervuras proximais de segmentos adjacentes unindo-se em ângulo obtuso na nervura excurrente T. dentata

Thelypteris conspersa (Schrad.) A.R. Sm., Univ. Calif. Publ. Bot. 59: 60. 1971. Nephrodium conspersum Schrad., Gött. Gel. Anz. 869. 1824.

Materiais selecionados: 22-XII-2004, P.B. Schwartsburd \& T. Takeuchi 557 (HUPG, SP), 558 (UPCB); 13-I-2005, P.B. Schwartsburd 625 (MBM, UPCB); 7-III-2005, P.B. Schwartsburd 687 (COR, $\mathrm{RB})$.

Distribuição: Grandes Antilhas, Panamá, Colômbia, Venezuela, Equador, Peru, Bolívia, Brasil (NE, CO, SE e S), Paraguai, Argentina (N) e Uruguai. 
Esta espécie foi encontrada como terrícola no interior das matas ciliares próximas às Lagoas Dourada e Tarumã, em matas alteradas com Pinus spp. e Eucalyptus spp. e em ambientes semi-ruderais.

Thelypteris dentata (Forssk.) E.P. St. John, Amer. Fern J. 26: 44. 1936. Polypodium dentatum Forssk., Fl. Aegypt.-Arab.: 185. 1775.

Materiais selecionados: 10-XI-2003, P.B. Schwartsburd 25 (HUPG, UPCB); 7-I-2004, P.H. Labiak \& P.B. Schwartsburd 3091 (UPCB); 6-IV-2004, P.B. Schwartsburd \& M. Nogueira Júnior 101 (MBM); 23-IV-2005, P.B. Schwartsburd et al. 759 (MBM).

Distribuição: Ásia, Ilhas do Pacífico e África; E.U.A. (SE), México (S), Mesoamérica, Antilhas, Colômbia, Venezuela, Equador, Peru, Bolívia, Brasil (N, NE, CO, SE e S), Paraguai, Argentina (N) e Uruguai.

Esta espécie foi encontrada como terrícola na borda e interior de matas alteradas com Pinus spp. e Eucalyptus spp. e em ambientes ruderais, tais como muros e calçadas.

Segundo Smith (1995c) e Mickel \& Smith (2004), esta é uma espécie de origem Paleotropical (tipo do Iêmen - Oriente Médio) e naturalizada na América. No PEVV, assim como em várias outras regiões do Estado, observa-se que esta espécie está amplamente difundida em ambientes ruderais e/ou profundamente antropizados, co-ocorrendo principalmente com Pteris vittata e Macrothelypteris torresiana.
Thelypteris interrupta (Willd.) K. Iwats., Jap. J. Bot. 38: 314. 1963. Pteris interrupta Willd., Phytogr. 13, t. 10. 1794.

Material selecionado: 5-IV-2004, P.B. Schwartsburd \& M. Nogueira Júnior 92 (HUPG, MBM, UPCB).

Distribuição: Ásia e África; E.U.A. (S), México (O), Mesoamérica, Antilhas, Colômbia, Venezuela, Guianas, Equador, Peru, Brasil (N, NE, CO, SE e S), Paraguai e Argentina (N).

Esta espécie foi encontrada como terrícola em áreas encharcadas dos Campos Gerais, formando grandes populações oriundas da ramificação do caule.

Thelypteris subg. Steiropteris (C. Chr.) K. Iwats.

Thelypteris hatschbachii A.R. Sm., Univ. Calif. Publ. Bot. 76: 22. 1980.

Materiais selecionados: 11-X-2003, P.H. Labiak \& P.B. Schwartsburd 2993 (HUPG, SP, UPCB); 18-XII-2004, P.B. Schwartsburd et al. 485 (BHCB, HUPG), 489 (MBM); 5-III-2006, P.B. Schwartsburd et al. 998 (MBM, UPCB).

Distribuição: Endêmica às regiões Sul e Sudeste do Brasil.

Esta espécie foi encontrada como terrícola no interior da Floresta com Araucária, especialmente ao meio de populações de Merostachys multiramea Hack. (ver também comentários de Lastreopsis amplissima).

\section{Trichomanes L., nom. cons.}

Chave para as espécies de Trichomanes encontradas no PEVV

1. Frondes com até $1,5 \mathrm{~cm}$ compr.; venação catádroma, tendendo a flabeliforme T. hymenoides

1. Frondes com mais de $3 \mathrm{~cm}$ compr.; venação anádroma ou oposta

2. Caule ereto ou curto-reptante

3. Caule curto-reptante a ascendente; raque densamente pilosa, com tricomas pluricelulares com a célula basal marcadamente distinta T. pilosum

3. Caule ereto; raque glabra ou com esparsos tricomas glandulares unicelulares T. rigidum

2. Caule longo-reptante

4. Raque não alada . T. capillaceum

4. Raque alada

5. Raque e margem da lâmina com tricomas estrelados pluricelulares T. anadromum

5. Raque glabra ou com diminutos tricomas glandulares, margem da lâmina glabra

6. Caule rígido, não filiforme, com $1 \mathrm{~mm}$ diâm. ou mais; frondes férteis com mais de $15 \mathrm{~cm}$ compr. T. radicans

6. Caule delgado, filiforme, com menos de $0,5 \mathrm{~mm}$ diâm.; frondes férteis com menos de $6 \mathrm{~cm}$ compr. T. diaphanum 
Trichomanes anadromum Rosenst., Fedde Repert. 21: 344.1925.

Materiais selecionados: 10-VI-2004, P.B. Schwartsburd \& F.B. Matos 183 (MBM), 219 (UPCB); 16-V-2005, P.B. Schwartsburd \& M. Nogueira Júnior 785 (HUPG, RB, SP).

Distribuição: Mesoamérica, Bolívia, Brasil (SE e S) e Uruguai.

Esta espécie foi encontrada no interior de matas ciliares dos Campos Gerais, exclusivamente sobre os troncos de Cyathea corcovadensis.

Trichomanes anadromum pode ser confundido com T. polypodioides L., principalmente pelo aspecto geral da fronde e indumento. Porém, T. polypodioides apresenta venação catádroma e soros no ápice dos segmentos, enquanto que T. anadromum apresenta venação anádroma e soros na axila acroscópica dos segmentos.

Sehnem (1971) comenta que esta espécie aparenta ter especificidade com Dicksonia sellowiana, entretanto, o presente trabalho registrou esta espécie somente como epífita de Cyathea corcovadensis.

Trichomanes capillaceum L., Sp. pl.: 1099. 1753.

Materiais selecionados: 11-X-2003, P.H. Labiak \& P.B. Schwartsburd 2967 (HUPG, MBM, SP, UPCB); 21-VIII-2004, P.B. Schwartsburd et al. 307 (UPCB); 8-I-2005, P.B. Schwartsburd et al. 606 (MBM); 6-III-2005, P.B. Schwartsburd et al. 683 (UPCB).

Distribuição: México (S), Mesoamérica, Grandes Antilhas, Colômbia, Venezuela, Equador, Peru, Brasil (SE e S) e Uruguai.

Esta espécie foi encontrada principalmente como epífita de Pteridófitas arborescentes (Cyathea spp. e Alsophila setosa), no interior da Floresta com Araucária, e como rupícola nas Formações Areníticas.

Trichomanes diaphanum Kunth, Nov. Gen. Sp. 1: 25. 1816.

Material selecionado: 7-I-2004, P.H. Labiak \& P.B. Schwartsburd 3084 (HUPG, MBM, RB, SP, UPCB).

Distribuição: México (S), Mesoamérica, Antilhas, Trinidad, Colômbia, Venezuela, Guianas, Equador, Peru e Brasil (SE e S).

Esta espécie foi encontrada como rupícola às margens de riachos, no interior da Floresta com Araucária.
Trichomanes diaphanum pode ser confundido com T. pyxidiferum L., que apresenta o tecido laminar paralelo às nervuras nitidamente dobrado, indúsio parcialmente imerso no tecido laminar, com as nervuras laterais nitidamente visíveis e ápice pouco desenvolvido. Enquanto que T. diaphanum não apresenta tecido laminar dobrado e o indúsio é totalmente exerto, com as nervuras laterais não aparentes e o ápice desenvolvido e labiado.

Trichomanes hymenoides Hedw., Fil. Gen. Sp.: 14. 1799.

Materiais selecionados: 18-XI-2000, M. Borgo \& F.M. Ramos 844 (UPCB); 19-X-2005, P.B. Schwartsburd et al. 915 (HUPG, MBM, UPCB).

Distribuição: México (S), Mesoamérica, Antilhas, Trinidad, Colômbia, Venezuela, Equador, Peru, Bolívia, Brasil (NE, CO, SE e S), Paraguai, Argentina (NE) e Uruguai.

Esta espécie foi encontrada como epífita no interior da Floresta com Araucária e também como rupícola nas Formações Areníticas.

Trichomanes pilosum Raddi, Opusc. Sci. Bol. 3: 296. 1819.

Materiais selecionados: 20-XII-2004, P.B. Schwartsburd et al. 530 (MBM, UPCB); 12-I-2005, P.B. Schwartsburd \& A.C. Hatschbach 614 (MBM, UPCB), 615 (RB); 28-X-2005, P.B. Schwartsburd et al. 956 (HUPG).

Distribuição: Bolívia, Brasil (CO, SE e S), Paraguai e Uruguai.

Esta espécie foi encontrada como rupícola no interior da Floresta com Araucária, nas Formações Areníticas, em arenitos isolados dos Campos e em córregos e cachoeiras dos Campos.

Aparentemente esta espécie apresenta uma grande variação morfológica de acordo com o ambiente em que os indivíduos ocorrem. Os indivíduos das frestas dos arenitos isolados dos Campos Gerais (parcialmente heliófilos, com pouca umidade disponível) apresentam as frondes férteis com 3-8 cm compr., os indivíduos das Formações Areníticas, do interior da Floresta e de cachoeiras dos Campos (ombrófilos ou heliófilos com grande umidade disponível) apresentam as frondes férteis com mais de $10 \mathrm{~cm}$ compr. 
Trichomanes radicans Sw., J. Bot. (Schrader) 1800(2): 97. 1801.

Materiais selecionados: 11-X-2003, P.H. Labiak \& P.B. Schwartsburd 2975 (HUPG, MBM, SP, UPCB); 21-VIII-2004, P.B. Schwartsburd et al. 315 (RB, UPCB); 14-XII-2004, P.B. Schwartsburd \& F.B. Matos 449 (HUPG, SP), 461 (MBM, UPCB); 8-I-2005, P.B. Schwartsburd et al. 601 (UPCB).

Distribuição: Ásia, Europa (O), África e Ilhas do Atlântico; México, Mesoamérica, Antilhas, Colômbia, Venezuela, Guianas, Equador, Peru, Bolívia, Brasil (N, SE e S) e Paraguai.

Esta espécie foi encontrada como hemi-epífita no interior da Floresta com Araucária, principalmente próxima a córregos e riachos.

Trichomanes radicans, T. kunzeanum Hook., T. rupestre (Raddi) Bosch e T. collariatum Bosch formam um complexo de espécies que precisam ser melhor delimitadas. As diferenças entre algumas destas espécies propostas por Sehnem (1971), Tryon \& Stolze (1989b), Lellinger (1991) e Pacheco (1995) não se mostraram funcionais para o material do PEVV, motivo pelo qual se optou em nomear o presente material com o binômio mais antigo, em seu sensu lato.

Trichomanes rigidum Sw., Prodr.: 137. 1788.

Materiais selecionados: 10-VI-2004, P.B. Schwartsburd \& F.B. Matos 180 (HUPG, MBM); 29-X-2005, P.B. Schwartsburd et al. 978 (UPCB); 5-III-2006, P.B. Schwartsburd et al. 995 (UPCB).

Distribuição: Ásia, Oceania e África; México (S), Mesoamérica, Antilhas, Colômbia, Venezuela, Guianas, Equador, Peru, Bolívia e Brasil (CO, SE e S).

Esta espécie foi encontrada como terrícola no interior da Floresta com Araucária, às margens de córregos.

O hábito terrícola, o caule e as frondes eretos caracterizam facilmente esta espécie. Tais características são também verificadas em Trichomanes elegans Rich., a qual diferencia-se pelo porte maior (frondes com até $90 \mathrm{~cm}$ compr.), a lâmina com coloração azulada e com duas ou mais camadas de células de espessura. Enquanto que T. rigidum apresenta menor porte (até $35 \mathrm{~cm}$ compr.), a lâmina sem tom azulado e com apenas uma camada celular de espessura (Sehnem 1971, Tryon \& Stolze 1989b).

\section{Vittaria Sm.}

Vittaria lineata (L.) Sm., Mem. Acad. Roy. Sci. (Turin) 5: 421. 1793. Pteris lineata L., Sp. pl.: 1073. 1753.

Materiais selecionados: 15-IV-1992, J. Cislinski \& A.C. Cervi 135 (UPCB); 11-X-2003, P.H. Labiak \& P.B. Schwartsburd 2962 (HUPG, MBM, UPCB); 10-VI-2004, P.B. Schwartsburd \& F.B. Matos 193 (COR); 18-XII-2004, P.B. Schwartsburd et al. 488 (SP); 19-XII-2004, P.B. Schwartsburd et al. 514 (UPCB); 19-X-2005, P.B. Schwartsburd et al. 910 (HUPG, MBM).

Distribuição: E.U.A. (S), México, Mesoamérica, Antilhas, Trinidad, Colômbia, Venezuela, Guianas, Equador, Peru, Bolívia, Brasil (N, NE, CO, SE e S), Paraguai e Uruguai.

Esta espécie foi encontrada como rupícola e epífita, nas Formações Areníticas e no interior da Floresta com Araucária.

Difere de Vittaria graminifolia Kaulf. e V. scabrida Klotzsch ex Fée, duas espécies semelhantes, por apresentar esporos monoletes, parafáfises filiformes e escamas do caule com a margem marcadamente denteada e ápice longofiliforme. Enquanto que V. graminifolia e V. scabrida apresentam esporos triletes, paráfises cuculiformes (V. scabrida) ou clavadas (V. graminifolia) e escamas do caule com a margem lisa ou levemente denteada e ápice não filiforme (Labiak \& Prado 1998).

Foram registradas 152 espécies de Pteridófitas ocorrentes no Parque Estadual de Vila Velha, distribuídas em 54 gêneros. Este número representa cerca de $25 \%$ das 600 espécies de Pteridófitas do Sul e Sudeste do Brasil, estimadas por Tryon \& Tryon (1982), e cerca de $11 \%$ das 1.300 espécies consideradas por Prado (1998) para o Brasil.

Os gêneros mais representativos foram: Asplenium (11 spp.), Blechnum (10 spp.), Thelypteris (10 spp.) e Pecluma, Polypodium e Trichomanes (com 7 spp. cada).

Quanto aos ambientes preferenciais, observouse uma clara importância da configuração fitofisionômica, geográfica e geológica na diversidade de espécies encontradas, sendo sumarizados como segue: 47 spp. ocorrentes nos Campos Gerais (25 exclusivas), destas, 22 spp. (oito exclusivas) ocorrem nos Campos secos e 37 spp. (12 exclusivas), nos Campos úmidos; $100 \mathrm{spp}$. ocorrentes no interior da Floresta com 
Araucária (50 exclusivas) e de matas alteradas; 60 spp. ocorrentes nas galerias e paredões úmidos das Formações Areníticas (19 exclusivas); e $10 \mathrm{spp}$. ocorrentes em ambientes ruderais ou semi-ruderais (quatro exclusivas).

A presença de três ambientes marcadamente distintos no PEVV (Florestas, Campos e formações rochosas), pode ser uma explicação razoável para a elevada riqueza de espécies encontrada. Apesar da Floresta com Araucária apresentar um maior número de espécies (100 spp.), as Formações Areníticas mostraram ser também um local bastante propício à ocorrência de Pteridófitas (60 spp.), com algumas destas estritamente específicas a este tipo de habitat, tais como: Alsophila capensis subsp. polypodioides, Blechnum divergens, Ctenitis bigarellae, Eriosorus aff. myriophyllus e Phlebodium areolatum, além de várias espécies de Hymenophyllum.

Os Campos também revelaram um alto número de espécies, muito maior do que o esperado para uma região de estepe, algumas formando grandes e densas populações, como: Pteridium arachnoideum, Adiantopsis chlorophylla, Polypodium vacillans, Dicranopteris flexuosa, Sticherus lanuginosus e Osmunda spp.); e outras com os indivíduos ocorrendo relativamente isolados entre si, como: Blechnum schomburgkii, Doryopteris crenulans, Lophosoria quadripinnata, Cyathea atrovirens, Cyathea corcovadensis e Anemia raddiana.

Cabe ressaltar a grande riqueza dos gêneros Trichomanes e Hymenophyllum (13 espécies) que, embora sejam mais comuns em áreas de Floresta Atlântica, apresentaram-se com uma riqueza elevada na área do PEVV. Enquanto Hymenophyllum foi mais comumente encontrado nas galerias dos arenitos, as espécies de Trichomanes foram encontradas preferencialmente nas áreas de Floresta com Araucária.

É de consenso geral que a Floresta Atlântica s.s. apresente maior riqueza de espécies dos diferentes grupos biológicos em geral do que a Floresta com Araucária. Como exemplo, os dados obtidos por Dittrich et al. (2005) para o Parque Estadual Pico do Marumbi revelam uma altíssima riqueza de Pteridófitas para esse bioma: 81 espécies em uma seção de apenas um hectare.

Uma comparação que reflete esta idéia é o número de espécies de Pteridófitas epífitas (incluindo hemi-epífitas e epífitas acidentais) encontradas pelo presente trabalho (30 spp.), e o levantado por Labiak \& Prado (1998) para a Reserva de Volta Velha, em
Itapoá-SC (59 spp.). Um fato curioso é que algumas espécies ocorrentes em ambas as áreas não foram registradas como epífitas pelo presente trabalho, e.g. Rumohra adiantiformis, Cochlidium serrulatum, Selaginella flexuosa, Polypodium chnoophorum e Pecluma paradiseae, o que poderia estar relacionado às diferenças climáticas e de disponibilidade de nichos nas diferentes áreas.

Porém, em uma outra comparação, mais consistente na medida em que todas as formas biológicas (terrícolas, epífitas, rupícolas, etc.) de Pteridófitas foram amostradas, este consenso geral não é confirmado: Salino et al. (2005) registraram para a Ilha do Mel (FOD) 114 spp. - área aproximada de 2.894 ha e altitudes variando de 0 a $148 \mathrm{~m}$ (Britez \& Marques 2005); e o presente trabalho, $152 \mathrm{spp}$. Apesar do PEVV apresentar uma área de aproximadamente 1.000 ha a mais que a Ilha do Mel, uma grande área do PEVV encontra-se alterada (ou em processo de regeneração natural), descartando-se assim o tamanho da área como justificativa para a maior riqueza. Talvez uma maior amplitude altitudinal, encontrada no PEVV, poderia estar influenciando no maior número de espécies registradas.

A análise da distribuição geográfica das espécies encontradas resultou em $15 \mathrm{spp}$. (10\%) com distribuição Circum-antártica, quatro spp. (3\%) Atlânticas, três spp. (2\%) Pacíficas, 53 spp. (36\%) Americanas, 46 spp. (31\%) Sul-Americanas e 27 spp. (18\%) endêmicas ao Brasil. Das 27 spp. endêmicas do Brasil, 14 (9\% do total) são endêmicas às regiões Sul e Sudeste e, destas, uma sp. (menos de 1\%) é endêmica ao Estado do Paraná. Este número é inferior ao grau de endemismo estimado por Tryon \& Tryon (1982), para o Sul e Sudeste do Brasil (40\%), bem como para o obtido por Labiak \& Prado (1998), 25\% endêmicas do Brasil.

O menor número de espécies endêmicas talvez seja reflexo da situação austral de localização do PEVV, aliada às condições climáticas mais típicas de regiões temperadas. Embora o trabalho de Labiak \& Prado (1998) tenha sido realizado numa latitude mais sul, as condições climáticas são evidentemente diferenciadas e mais próximas de uma condição tropical, dado à baixa altitude e proximidade com o Oceano Atlântico; além do fato de terem sido analisadas apenas as epífitas - grupo conhecido por apresentar muita especiação e endemismo, como verificado em Cactaceae, Bromeliaceae e Orchidaceae, por exemplo. 
Quanto às espécies exóticas, Macrothelypteris torresiana, Thelypteris dentata, Neprolepis cordifolia, Deparia petersenii e Pteris vittata, são consideradas invasoras, de origem extra-Americana, mas com ocorrência espontânea ou subespontânea em regiões do nosso continente.

No PEVV, com a exceção de Deparia petersenii, tais espécies foram encontradas ocorrendo estritamente em ambientes antropizados, matas profundamente alteradas ou ambientes ruderais. Deparia petersenii foi encontrada no interior da Floresta com Araucária, próxima a córregos.

\section{Agradecimentos}

Ao Programa de Pós-Graduação em Botânica (UFPR) e ao CAPES pela concessão da bolsa de Mestrado ao primeiro autor. Somos gratos também ao Dr. Jefferson Prado e ao Dr. Willian Rodrigues, pelos comentários e correções sugeridas, e aos colegas botânicos que nos auxiliaram neste trabalho: Dr. Gert Hatschbach, Dra. Lana Sylvestre, Dr. Vinícios Dittrich, Dr. Alan Smith, Dr. Alexandre Salino, Dra. Jasívia Gonzáles, Msc. Claudine Mynssen, Msc. Simone Pereira, Msc. Miodeli Nogueira Júnior, Msc. Cyntia Sakagami, Msc. Elton Assis, Ana Carolina Hatschbach Cardon e Fernando Bittencourt Matos.

\section{Literatura citada}

Alston, A.H.G. 1958. The Brazilian species of Elaphoglossum. Boletim da Sociedade Broteriana 38: 1-32.

Angely, J. 1963. Flora Pteridophyta do Paraná. Instituto Paranaense de Botânica 23: 1-48.

Athayde Filho, F.P. \& Windisch, P.G. 2003. O gênero Pecluma M.G. Price (Polypodiaceae, Pteridophyta) no Estado do Rio Grande do Sul. Pesquisas (Botânica) 53: 65-77.

Barros, I.C.L., Lira, O.C. \& Silva, A.J.R. 1988. Distribuição geográfica das pteridófitas ocorrentes no Estado de Pernambuco, Brasil. Acta Botanica Brasilica 2: 47-84.

Bittencourt, S., Corte, A.P.D. \& Sanquetta, C.R. 2004. Estrutura da comunidade de Pteridophyta em uma Floresta Ombrófila Mista, sul do Paraná, Brasil. Silva Lusitana 12: 243-254.

Bodziak Júnior, C. \& Maack, R. 1946. Contribuição ao conhecimento dos solos dos Campos Gerais no Estado do Paraná. Arquivos de Biologia e Tecnologia 1: 197-214.

Borgo, M. \& Silva, S.M. 2003. Epífitos vasculares em fragmentos de Floresta Ombrófila Mista, Curitiba, Paraná, Brasil. Revista Brasileira de Botânica 3: 391-401.
Brade, A.C. 1961. O gênero Elaphoglossum (Polypodiaceae) no Brasil: I. Chave para determinar as espécies brasileiras. Rodriguésia 35, 36: 20-47.

Brade, A.C. 1971. O gênero Polybotrya no Brasil. Bradea 9: 57-67.

Britez, R.M. \& Marques, M.C.M. 2005. Caracterização geral. In: M.C.M. Marques \& R.M. Britez, (orgs.). História natural e conservação da Ilha do Mel. Editora UFPR, Curitiba, pp. 13-17.

Cervi, A.C., Acra, L.A., Rodrigues, L., Train, S., Ivanchechen, S.L. \& Moreira, A.L.O.R. 1987. Contribuição ao Conhecimento das Pteridófitas de uma Mata de Araucária, Curitiba, Paraná, Brasil. Acta Biológica Paranaense 16: 77-85.

Christ, H. 1899. Monographie des genus Elaphoglossum. Kommissions-Verlag von Georg \& Co. Basel, Genève und Lyon.

Christensen, C. 1913. A Monograph of the genus Dryopteris part I - the Tropical American pinnatifidbipinnatifid Species. Mémoirs de l'Académie Royale des Sciences et des Lettres de Danemark, $7 \mathrm{me}$ série, $\mathrm{t}$. X, n. 2: 53-282.

Cislinski, J. 1996. O gênero Diplazium Sw. (Dryopteridaceae, Pteridophyta) no Estado do Paraná, Brasil. Acta Botanica Brasilica 10: 59-77.

Dittrich, V.A.O. 2005. Estudos taxonômicos no gênero Blechnum L. (Pterophyta: Blechnaceae) para as regiões Sudeste e Sul do Brasil. Tese de Doutorado, Universidade Estadual Paulista "Júlio de Mesquita Filho", Rio Claro.

Dittrich, V.A.O., Kozera, C. \& Silva, S.M. 1999. Levantamento florístico dos epífitos vasculares do Parque Barigüí, Curitiba, Paraná, Brasil. Iheringia (série Botânica) 52: 11-21.

Dittrich, V.A.O., Waechter, J.L. \& Salino, A. 2005. Species richness of pteridophytes in a montane Atlantic rain forest plot of Southern Brazil. Acta Botanica Brasilica 19:519-525.

Dombrowski, L.T.D. 1972. Coleção de Pteridófitas do Paraná no Instituto de Defesa do Patrimônio Natural (IDPN). Araucariana 2: 1-30.

Evans, A.M. 1969. Interspecific relationships in the Polypodium pectinatum-plumula complex. Annals of the Missouri Botanical Garden 55: 193-293.

Fernandes, I. 1997. Taxonomia e fitogeografia de Cyatheaceae e Dicksoniaceae nas regiões Sul e Sudeste do Brasil. Tese de Doutorado, Universidade de São Paulo, São Paulo.

Hatschbach, G. \& Moreira Filho, H. 1972. Catálogo florístico do Parque Estadual de Vila Velha (Estado do Paraná Brasil). Boletim da Universidade Federal do Paraná 28: $1-49$.

Hensen, R.V. 1990. Revision of the Polypodium loriceumcomplex (Filicales, Polypodiaceae). Nova Hedwigia 50: 279-336. 
Hertel, R.J.G. 1949. Contribuição à ecologia da flora epífita da Serra do Mar (vertente oeste) do Paraná. Tese de concurso à livre docência da cadeira de Botânica da Faculdade de Filosofia, Ciências e Letras da Universidade do Paraná. Curitiba.

Hirai, R.Y. \& Prado, J. 2000. Selaginellaceae Willk. no Estado de São Paulo, Brasil. Revista Brasileira de Botânica 23: 313-339.

IAPAR. 1978. Cartas climáticas do Estado do Paraná. Instituto Agronômico do Paraná, Londrina.

IBAMA. 1992. Portaria $\mathrm{N}^{\circ}$ 37-N, 03/04/92, Lista oficial de espécies da flora brasileira ameaçada de extinção. http:/ /www2.ibama.gov.br/flora/extincao.htm (acesso em 01.03.2005).

Kato, M. 1993. Deparia Hooker \& Greville. In: Flora of North America Editorial Committee (eds.). Flora of North America: Pteridophytes and Gimnosperms. Oxford University Press, New York, v. 2, pp. 254-255.

Kersten, R.A. \& Silva, S.M. 2001. Composição florística e estrutura do componente epifítico vascular em floresta da planície litorânea da Ilha do Mel, Paraná, Brasil. Revista Brasileira de Botânica 24: 213-226.

Kessler, M. \& Smith, A.R. 2005. Seven new species, 13 new combinations, and one new name of Polypodiaceae from Bolivia. Candollea 60: 271-288.

Kramer, K.U. 1957. A revision of the genus Lindsaea in the New World. Acta Botanica Neerlandica 6: 97-290.

Labiak, P.H. \& Prado, J. 1998. Pteridófitas epífitas da Reserva Volta Velha, Itapoá - Santa Catarina, Brasil. Boletim do Instituto de Botânica 11: 1-79.

Labiak, P.H. \& Prado, J. 2003. Grammitidaceae (Pteridophyta) no Brasil com ênfase nos gêneros Ceradenia, Cochlidium e Grammitis. Hoehnea 30: 243-283.

Legrand, D. \& Lombardo, A. 1958. Flora del Uruguay: I Pteridophyta. Museo Nacional de Historia Natural: 1-67.

Lellinger, D.B. 1991. Notes on Neotropical Hymenophyllaceae. American Fern Journal 81: 24-37.

León, B. 1992. A taxonomic revision of the fern genus Campyloneurum (Polypodiaceae). Tese de Doutorado, Universidad Nacional Mayor de San Marcos, Peru.

Mickel, J.T. 1962. A monographic study of the fern genus Anemia, subgenus Coptophyllum. Iowa State Journal of Science 4: 349-482.

Mickel, J.T. 1995. Elaphoglossum Schott ex J. Sm. In: P.E. Berry, B.K. Holst \& K. Yatskievych (eds.). Pteridophytes, Spermatophytes, Acathaceae - Araceae. In: J.A. Steyemark, P.E. Berry \& B.K. Holst, (eds.). Flora of the Venezuelan Guayana, v. 2. Missouri Botanical Garden, St. Louis, pp. 89-105.

Mickel, J.T. \& Beitel, J.M. 1988. Pteridophyte Flora of Oaxaca, México. Memoirs of the New York Botanical Garden 46: 1-568.
Mickel, J.T. \& Smith, A.R. 2004. The Pteridophytes of Mexico. Memoirs of the New York Botanical Garden 88: $1-1055$.

Moran, R.C. 1987. Monograph of the Neotropical fern genus Polybotrya (Dryopteridaceae). Illinois Natural History Survey Bulletin 34: 1-138.

Moran, R.C. 1995a. Histiopteris (J. Agardh) J. Sm. In: R.C. Moran \& R. Riba (eds.). Psilotaceae a Salviniaceae. In: G. Davidse, M. Sousa \& S. Knapp (eds.). Flora Mesoamericana. Universidad Nacional Autónoma de México, Ciudad de México, v. 1, p. 153.

Moran, R.C. 1995b. Hypolepis Bernh. In: R.C. Moran \& R. Riba (eds.). Psilotaceae a Salviniaceae. In: G. Davidse, M. Sousa \& S. Knapp (eds.). Flora Mesoamericana. Universidad Nacional Autónoma de México, Ciudad de México, v. 1, pp. 153-157.

Moran, R.C. 1995c. Phlebodium (R. Br.) J. Sm. In: R.C. Moran \& R. Riba (eds.). Psilotaceae a Salviniaceae. In: G. Davidse, M. Sousa \& S. Knapp (eds.). Flora Mesoamericana. Universidad Nacional Autónoma de México, Ciudad de México, v. 1, pp. 345-346.

Moran, R.C. 1995d. Sticherus C. Presl. In: R.C. Moran \& R. Riba (eds.). Psilotaceae a Salviniaceae. In: G. Davidse, M. Sousa \& S. Knapp (eds.). Flora Mesoamericana. Universidad Nacional Autónoma de México, Ciudad de México, v. 1, pp. 59-62.

Moran, R.C. \& Smith, A.R. 2001. Phytogeographic relationships between neotropical and AfricanMadagascan pteridophytes. Brittonia 53: 304-351.

Morton, C.V. 1947. The American species of Hymenophyllum section Sphaerocionium. Contributions from the United States National Herbarium 29: 139-201.

Nauman, C.E. 1995. Nephrolepis Schott. In: R.C. Moran \& R. Riba (eds.). Psilotaceae a Salviniaceae. In: G. Davidse, M. Sousa \& S. Knapp (eds.). Flora Mesoamericana. Universidad Nacional Autónoma de México, Ciudad de México, v. 1, pp. 286-289.

Navarrete, H. \& Øllgaard, B. 2000. The fern genus Dennstaedtia (Dennstaedtiaceae) in Ecuador, - new characters, new species and a new combination. Nordic Journal of Botany 20: 319-346.

Nessel, H. 1955. Lycopodiaceae. In: F.C. Hoehne (ed.). Flora Brasilica. Companhia Brasileira de Impressão e Propaganda, São Paulo, fasc. 11, v. 2.

Novelino, R.F. 1998. Distribuição geográfica e ecologia das espécies de Elaphoglossum Schott ex J. Sm. (Pteridophyta) que ocorrem no Brasil. Boletim do Herbário Ezechias Paulo Heringer 3: 5-26.

Øllgaard, B. 1994. Lycopodiaceae. In: R.M. Tryon \& R.G. Stolze (eds.). Pteridophyta of Peru, part VI: 22 Ophioglossaceae - 28. Isoetaceae. Fieldiana Botany, new series 34: 16-66. 
Øllgaard, B. \& Windisch, P.G. 1987. Sinopse das Licopodiáceas do Brasil. Bradea 5: 1-43.

Østergaard-Andersen, E.O. \& Øllgaard, B. 2001. Gleicheniaceae. In: G. Harling \& L. Andersson (eds.). Flora of Ecuador 66: 105-170.

Pacheco, L. 1995. Trichomanes L. In: R.C. Moran \& R. Riba (eds.). Psilotaceae a Salviniaceae. In: G. Davidse, M. Sousa \& S. Knapp (eds.). Flora Mesoamericana. Universidad Nacional Autónoma de México, Ciudad de México, v. 1, pp. 71-83.

Parris, B.S. 2001. Circum-Antarctic continental distribution patterns in pteridophyte species. Brittonia 53:270-283.

Pichi-Sermolli, R.E.G. 1996. Authors of scientific names in Pteridophyta. Royal Botanical Garden, Kew.

Ponce, M.M. 1995. Las especies austrobrasileñas de Thelypteris subg. Amauropelta (Thelypteridaceae, Pteridofita). Darwiniana 33: 257-283.

Prado, J. 1995. Ferns. In: B.L. Stannard (ed.). Flora of the Pico das Almas, Chapada Diamantina - Bahia, Brazil. Royal Botanic Gardens, Kew, pp. 85-110.

Prado, J. 1997. Flora da Serra do Cipó, Minas Gerais: Pteridaceae - Adiantoideae e Taenitidoideae. Boletim de Botânica da Universidade de São Paulo 16: 115-118.

Prado, J. 1998. Pteridófitas do Estado de São Paulo In: C.E.M. Bicudo \& G.J. Shepherd (eds.). Biodiversidade do Estado de São Paulo, v. 2.- Fungos macroscópicos e plantas. FAPESP, São Paulo.

Prado, J. 2004a. Criptógamos do Parque Estadual das Fontes do Ipiranga, São Paulo, SP. Pteridophyta: 17. Pteridaceae. Hoehnea 31: 39-49.

Prado, J. 2004b. Criptógamos do Parque Estadual das Fontes do Ipiranga, São Paulo, SP. Pteridophyta: 5. Dennstaedtiaceae. Hoehnea 31: 11-22.

Prado, J. \& Windisch, P.G. 2000. The genus Pteris L. (Pteridaceae) in Brazil. Boletim do Instituto de Botânica 13: 103-199.

Rojas-Alvarado, A.F. 2002. New species, new combinations and new distribuitions in neotropical species of Elaphoglossum (Lomariopsidaceae). Revista de Biología Tropical 50: 969-1006.

Salino, A. 2002. New species and combinations in Thelypteris subg. Goniopteris (Thelypteridaceae). Brittonia 54: 331-339.

Salino, A. \& Semir, J. 2004. Thelypteris subg. Amauropelta (Kunze) A.R. Sm. (Thelypteridaceae - Pterophyta) no Estado de São Paulo, Brasil. Lundiana 5: 83-112.

Salino, A., Silva, S.M., Dittrich, V.A.O. \& Britez, R.M. 2005. Flora pteridofítica. In: M.C.M. Marques \& R.M. Britez (orgs.). História natural e conservação da Ilha do Mel. Editora UFPR, Curitiba, pp. 85-101.

Schwartsburd, P.B., Labiak, P.H. \& Salino, A. 2007. A new species of the fern genus Ctenitis from Southern Brazil. Brittonia 59: 29-32.
Sehnem, A. 1961. Uma coleção de Pteridófitos do Rio Grande do Sul, V. Pesquisas (Botânica) 13: 1-52.

Sehnem, A. 1967. Maratiáceas. In: R. Reitz (ed.). Flora Ilustrada Catarinense. Herbário Barbosa Rodrigues, Itajaí.

Sehnem, A. 1968. Blecnáceas. In: R. Reitz (ed.). Flora Ilustrada Catarinense. Herbário Barbosa Rodrigues, Itajaí.

Sehnem, A. 1970a. Gleiqueniáceas. In: R. Reitz (ed.). Flora Ilustrada Catarinense. Herbário Barbosa Rodrigues, Itajaí.

Sehnem, A. 1970b. Polipodiáceas. In: R. Reitz (ed.). Flora Ilustrada Catarinense. Herbário Barbosa Rodrigues, Itajaí.

Sehnem, A. 1971. Himenofiláceas. In: R. Reitz (ed.). Flora Ilustrada Catarinense. Herbário Barbosa Rodrigues, Itajaí.

Sehnem, A. 1972. Pteridáceas. In: R. Reitz (ed.). Flora Ilustrada Catarinense. Herbário Barbosa Rodrigues, Itajaí.

Sehnem, A. 1979a. Aspidiáceas. In: R. Reitz (ed.). Flora Ilustrada Catarinense. Herbário Barbosa Rodrigues, Itajaí.

Sehnem, A. 1979b. Davaliáceas. In: R. Reitz (ed.). Flora Ilustrada Catarinense. Herbário Barbosa Rodrigues, Itajaí.

Smith, A.R. 1995a. Macrothelypteris (H. Itô) Ching. In: R.C. Moran \& R. Riba (eds.). Psilotaceae a Salviniaceae. In: G. Davidse, M. Sousa \& S. Knapp (eds.). Flora Mesoamericana. Universidad Nacional Autónoma de México, Ciudad de México, v. 1, pp. 164.

Smith, A.R. 1995b. Gleicheniaceae. In: P.E. Berry, B.K. Holst \& K. Yatskievych (eds.). Pteridophytes, Spermatophytes, Acathaceae - Araceae. In: J.A. Steyemark, P.E. Berry \& B.K. Holst (eds.). Flora of the Venezuelan Guayana, v. 2. Missouri Botanical Garden, St. Louis, pp. 128-135.

Smith, A.R. 1995c. Thelypteris Schmidel. In: R.C. Moran \& R. Riba (eds.). Psilotaceae a Salviniaceae. In: G. Davidse, M. Sousa \& S. Knapp (eds.). Flora Mesoamericana. Universidad Nacional Autónoma de México, Ciudad de México, v. 1, pp. 164-195.

Sota, E.R. de la. 1960. Polypodiaceae y Grammitidaceae Argentinas. Opera Lilloana 5: 1-229.

Sota, E.R. de la. 1965. Las especies escamosas del genero Polypodium L. (s. str.) en Brasil. Revista del Museo de La Plata 9: 243-271.

Sylvestre, L.S. 2001. Revisão taxonômica das espécies da família Aspleniaceae A. B. Frank ocorrentes no Brasil. Tese de Doutorado. Universidade de São Paulo, São Paulo.

Takeda, I.J.M. \& Farago, P.V. 2001. Vegetação do Parque Estadual de Vila Velha - Guia de Campo, v. 1. Editora Serzegraf, Curitiba. 
Tessmann, G. 1951. Atribuições da Botânica sistemática: notas críticas acerca do método, sistema e chave. Arquivos de Biologia e Tecnologia 5,6: 3-24.

Tryon, A.F. 1970. A monograph of the fern genus Eriosorus. Contributions from the Gray Herbarium of Harvard University 200: 54-174.

Tryon, R.M. \& Stolze, R.G. 1989a. Pteridophyta of Peru, part II: 13. Pteridaceae - 15. Dennstaedtiaceae. Fieldiana, Botany, new series 22: 1-128.

Tryon, R.M. \& Stolze, R.G. 1989b. Pteridophyta of Peru, part I: 1. Ophioglossaceae - 12. Cyatheaceae. Fieldiana, Botany, new series 20: 1-145.

Tryon, R.M. \& Stolze, R.G. 1991. Pteridophyta of Peru, part IV: 17. Dryopteridaceae. Fieldiana, Botany, new series 27: 1-176.
Tryon, R.M. \& Stolze, R.G. 1993. Pteridophyta of Peru, part V: 18. Aspleniaceae - 21. Polypodiaceae. Fieldiana, Botany, new series 32: 1-190.

Tryon, R.M. \& Tryon, A.F. 1982. Ferns and allied plants, with special reference to Tropical America. Editora Springer - Verlag, New York.

Veloso, H.P., Rangel Filho, A.L.R. \& Lima, J.C.A. 1991. Classificação da vegetação brasileira adaptada a um sistema universal. Fundação Instituto Brasileiro de Geografia e Estatística - IBGE, Departamento de Editoração, Rio de Janeiro.

Windisch, P.G. \& Nonato, F.R. 1999. Pteridófitas do Estado de Mato Grosso, Brasil: Vittariaceae. Acta Botanica Brasilica 13: 291-297.

Wons, I. 1982. Geografia do Paraná - Física, Humana e Econômica. $4^{\mathrm{a}}$ ed. Editora Ensino Renovado, Curitiba. 